\title{
Inhalt
}

Vorwort - V

Danksagung —XIII

1 Wer hat den Computer erfunden? - 1

$1.1 \quad$ Vorbemerkungen $\mathbf{- 1}$

1.2 Was ist ein Computer? -3

1.3 Was ist eine Turingmaschine? - 3

1.3.1 Aufbau der Turingmaschine - 3

1.3.2 Programmablauf -4

1.3.3 Bedeutung für die theoretische Informatik -5

1.3.4 Algorithmus -5

1.3.5 Universalmaschine - 6

1.4 Was ist ein Von-Neumann-Rechner? - 8

1.4.1 Aufbau eines Von-Neumann-Rechners - 8

1.5 Ist der Von-Neumann-Rechner eine Serien- oder eine Parallelmaschine? - $\mathbf{1 0}$

$\mathbf{1 . 6}$ Wer hat den Von-Neumann-Rechner erfunden? - $\mathbf{1 0}$

$\mathbf{1 . 7}$ Was bedeutet Speicherprogramm? — $\mathbf{1 1}$

1.7.1 Gespeicherte Programme sind nichts Neues - 11

1.7.2 Daten und Programm im gleichen Speicher $\mathbf{- 1 2}$

1.7.3 Rechner ohne und mit Programmspeicher - 13

1.7.4 Voraussetzungen für die Programmspeicherung -13

1.7.5 Schnellere Datenverarbeitung dank Programmspeicherung - 14

1.7.6 Was ist ein selbstveränderliches Programm? - 15

1.7.7 Ist die Turingmaschine selbstveränderlich? $\mathbf{- 1 8}$

1.7.8 Ist die Turingmaschine speicherprogrammiert? $-\mathbf{2 0}$

1.7.9 Turingmaschine: Programm und Daten auf demselben Speicher? (Speicherband als Programm -und Datenspeicher) - $\mathbf{2 1}$

1.7.10 Turingmaschine: Programm und Daten auf unterschiedlichen Speicherbändern? - 22

1.7.11 Rückwirkende Zeitzeugenaussagen - 22

$1.8 \quad$ Universeller Rechner $\neq$ speicherprogrammierter Rechner -24

1.9 Wer kam zuerst auf die Idee des Speicherprogramms? - 25

1.9.1 Kurt Gödel als Stammvater des Speicherprogramms? - 31

1.9.2 Zuses Ansätze zum gespeicherten Programm —32

1.9.3 Mechanik bremst Elektronik — 33

1.9.4 Durchbruch des Speicherprogramms dank von Neumann - 34

1.9.5 Turing, von Neumann oder Eckert/Mauchly? — 34 
1.9.6 Schlussfolgerungen -36

1.10 Wer hat als Erster die automatische Programmierung ausgedacht? 37

1.11 Wer hat den ersten Übersetzer (Compiler) geschaffen? - 39

1.12 Frühzeit der Programmierung — 41

1.13 Offene Fragen zur Informatikgeschichte - 42

1.14 Woher kamen die Baukenntnisse? — 43

1.14.1 Lehrveranstaltungen -44

1.14.2 Veröffentlichungen -45

1.14.3 Bau der ersten Rechenmaschinen - 47

1.14.4 Einführung in die Rechentechnik und Bestandsaufnahme (Überblick) - 48

1.15 Frühe Relais- und Röhrenrechner und ihre Nachfolger — 49

$\mathbf{1 . 1 6}$ Beweggründe für den Rechnerbau — $\mathbf{5 0}$

1.17 Wer war an der Entwicklung des Computers beteiligt? $-\mathbf{5 4}$

1.17.1 Charles Babbage - $\mathbf{5 5}$

1.17.2 Alan Turing - 55

1.17.3 John von Neumann -56

1.17.4 Konrad Zuse - $\mathbf{5 7}$

1.17.5 Weitere mögliche Erfinder - $\mathbf{5 7}$

1.17.6 Wer hat welche Rechenmaschine erfunden? - 57

1.18 Wo befindet sich die Wiege des Computers? - 59

1.19 Welcher Zeitpunkt ist bei einer Erfindung maßgebend? - 62

1.20 Wer gewann den Wettlauf? - 62

1.20.1 Wettlauf um die erste speicherprogrammierte Rechenanlage - 64

1.21 Welches ist der erste speicherprogrammierte Rechner? - 67

1.22 Wer hatte wieviel Einfluss auf die Rechnerentwicklung? - 72

1.22.1 Institute for advanced study, ein Besuchermagnet - $\mathbf{7 2}$

1.22.2 Wer war tonangebend? - 75

1.22.3 War Ada Lovelace wirklich die erste Programmiererin? - 85

1.22.4 Die Meinungen zu Turings Einfluss auf den Rechnerbau gehen auseinander $-\mathbf{8 8}$

1.23 Welches waren die einflussreichsten Rechenanlagen? — 95

1.23.1 Einflussreiche Musterrechner — 96

1.24 Welches waren die ersten marktfähigen Rechner? — 97

1.24.1 Ferranti mark 1 und Univac $1-97$

1.24.2 Leo 1 und IBM 701 bzw. $650-98$

1.24.3 Zuse Z4

1.25 Woher kam das Geld? — 98

$\mathbf{1 . 2 6}$ Misserfolge beim Rechnerbau — 101

1.27 Maschinen mit Schreibwerk -102 
1.28 Zeittafel: frühe elektromechanische und elektronische Digitalrechner 106

$\mathbf{1 . 2 9}$ Frühe Transistorrechner $\mathbf{- 1 0 7}$

$\mathbf{1 . 3 0}$ Jahrhundertelang geringer Rechenbedarf — 108

1.31 Pionierinnen und Pioniere als ACM- und IEEE-Preisträger — 109

$\mathbf{1 . 3 2}$ Jubiläen zur Geschichte der Rechentechnik — 111

2 Rechnerentwicklung in Deutschland - 113

2.1 Vorbemerkungen - $\mathbf{1 1 3}$

$2.2 \quad$ Plankalkül - 114

2.3 Frühe deutsche Relais- und Röhrenrechner — $\mathbf{1 1 4}$

2.3.1 Informatikpionier Konrad Zuse — 114

2.3.2 Zuses Prozessrechner - $\mathbf{1 1 7}$

2.3.3 Zuses logistisches Gerät und das Schachspiel - $\mathbf{1 1 8}$

2.3.4 Übernahme der Zuse KG durch BBC Mannheim mit Millionenverlust _-119

2.3.5 Weitere deutsche Relais- und Röhrenrechner - $\mathbf{1 2 0}$

$\mathbf{2 . 4} \quad$ Frühe deutsche Transistorrechner — $\mathbf{1 2 1}$

2.5 Die ersten deutschen Digitalrechner (Übersicht) - $\mathbf{1 2 2}$

2.5.1 Telefunken GmbH, Berlin: Rechnerbau in Konstanz — 123

2.5.2 Analog- und Hybridrechner von Dornier, Friedrichshafen $\mathbf{1 2 4}$

3 Rechnerentwicklung in Großbritannien -125

3.1 Vorbemerkungen $-\mathbf{1 2 5}$

3.2 Enigma - 126

3.2.1 Enigma, ein Rätsel — 126

3.3 Polnische Bombe und Turing-Welchman-Bombe - 129

3.3.1 Polnische Bombe -129

3.3.2 Elektromechanische Bombe $\mathbf{1 2 9}$

3.4 Colossus $\mathbf{1 3 2}$

3.4.1 Lorenz SZ 132

3.4.2 Der elektronische Koloss - 132

3.4.3 War Turing am Colossus beteiligt? - 135

3.4.4 Hat Churchill die Vernichtung aller Colossus-Rechner angeordnet? 136

3.5 Tunny -137

3.6 Enigma und Bombe, Lorenz und Colossus (Übersicht) 138

3.6.1 Ausgewählte Verschlüsselungsmaschinen - 138

3.6.2 Bomben und Colossi 139

3.7 Bletchley Park — 142

3.7.1 Decknamen - 142

3.7.2 Fachausdrücke $-\mathbf{1 4 2}$ 
3.7.3 Baracken - 143

3.7.4 Zur Geschichte von Bletchley Park — $\mathbf{1 4 4}$

3.8 Birkbeck College, Universität London —146

3.9 Imperial College, London $-\mathbf{1 4 7}$

3.10 Harwell-Rechner - $\mathbf{1 4 7}$

3.10.1 Harwell-Rechner: älteste betriebsbereite Relaisrechenmaschine — 147

3.11 Die ersten britischen Digitalrechner (Übersicht) — 149

$4 \quad$ Rechnerentwicklung in der Schweiz - 153

4.1 Zuses Relaisrechner und die ETH Zürich - 153

4.1.1 Wann erfuhr die ETH Zürich von der Zusemaschine? - 153

4.1.2 Wie erfuhr die ETH Zürich von der Zusemaschine? - 154

4.1.3 Zuse und die ETH Zürich - 156

4.1.4 Warum bereitete Zuse 1949 eine Flucht in die Schweiz vor? - 158

4.1.5 Wie viel kostete die Z4? -163

4.1.6 Wer bezahlte die Z4? - 165

4.1.7 Wie wurde der bedingte Sprung auf der Z4 umgesetzt? 165

4.1.8 Wofür wurde die Z4 verwendet? — 166

4.1.9 Bark und Z4 -168

4.2 Schwierigkeiten beim Bau des ersten Schweizer Computers - $\mathbf{1 7 0}$

4.2.1 Der zermürbende Bau des ersten Schweizer Elektronenrechners - 170

4.2.2 Kauf oder Eigenbau? - 172

4.2.3 Fünf statt drei Jahre Bauzeit -174

4.2.4 Röhrenrechner statt Relaisrechner - $\mathbf{1 7 4}$

4.2.5 Verdruss mit der Magnettrommel — 175

4.2.6 Der Chefingenieur verlässt das Schiff vorzeitig — 177

4.2.7 Wollte IBM die Vollendung der Ermeth behindern? — 178

4.2.8 Auseinandersetzungen mit Remington Rand wegen Vertragsbruchs - $\mathbf{1 7 9}$

4.2.9 Verhandlungen mit der Industrie - $\mathbf{1 7 9}$

4.2.10 Das Vorhaben gelingt mithilfe des Schulratspräsidenten $-\mathbf{1 8 0}$

4.2.11 Probleme auch im Ausland - 181

4.3 Warum scheiterte der Aufbau einer Schweizer IT-Industrie in den 1950er Jahren?-181

4.3.1 Vorwürfe an die Schweizer Industrie - 182

4.3.2 Anfragen aus der Industrie $-\mathbf{1 8 3}$

4.3.31 Warum nur der Trommelspeicher? -184

4.3.4 Haslers Marktaussichten - $\mathbf{1 8 5}$

4.3.5 Hat der Chefingenieur die Vermarktung der Ermeth verhindert? - 186

4.3.6 Folgerungen -187

4.4 Bau von Magnettrommelspeichern in Zürich -189

4.4.1 Z4: Versuchstrommel 189 
4.4.2 Ermeth: Versuchstrommel $\mathbf{1 9 0}$

4.4.3 Ermeth: große Trommel $\mathbf{1 9 0}$

4.5 Ermeths Nachfolge - 191

4.5.1 Die ETH Zürich war 1964 mehrere Monate lang ohne Großrechner — 191

4.5.2 Großrechnerkauf führt zur Anschaffung von

Tischrechenmaschinen - 192

4.6 Lilith, Ceres, Smaky und Gigabooster — 194

4.6.1 Lilith und Ceres - 194

4.6.2 Music und Gigabooster $\mathbf{1 9 6}$

4.6.3 Smaky - 197

4.7 Zuses Rechenlocher M9 und Remington Rand - 198

4.7.1 M9 - das Gesellenstück — 203

4.8 Transistorrechner Cora von Contraves - $\mathbf{2 1 0}$

4.9 Heinz Rutishauser, ein vergessener Pionier - 212

4.9.1 Rutishauser und die universelle Turingmaschine $-\mathbf{2 1 5}$

4.9.2 Grundlagenwerk zum Rechnerbau - $\mathbf{2 1 5}$

4.10 Wer war an den Entscheidungen zur Zuse Z4 und zur Ermeth beteiligt? 216

4.11 Kommission zur Entwicklung von Rechengeräten in der Schweiz - 218

4.12 Wer hat wann und wo an den Gesprächen zur Z4 teilgenommen? - 219

4.13 Wer hat an den Gesprächen zur Ermeth teilgenommen? - 221

$5 \quad$ Dokumente zur Z4 und zur Ermeth -223

5.1 Vorbemerkungen -223

5.2 Grundvertrag zur Z4 zwischen Zuse und der ETH (1949) - 224

5.3 Zusatzvertrag zur Z4 zwischen Zuse und der ETH (1949) - 234

5.4 Nachträgliche Bestellung der ETH zur Z4 (1950) - 238

5.5 Prüfbericht der ETH zur Z4 (1949) - $\mathbf{2 4 0}$

5.6 Abnahmeprotokoll zur Z4 (1950) - 248

5.7 Schlussrechnung der Zuse KG für die Z4 (1950) $\mathbf{2 5 0}$

5.8 Vereinbarung zur Rückgabe der Z4 an die Zuse KG (1955) - 251

5.9 Projektantrag für den Bau der Ermeth (1953) — 253

5.10 Lizenzvertrag zum Nachbau des Magnettrommelspeichers (1955) — 267

5.11 Forschungsauftrag von Hasler und Paillard an die ETH (1957) — 272

6 Weltweite Entwicklung der Rechentechnik - 275

6.1 Vorbemerkungen $-\mathbf{2 7 5}$

6.2 Argentinien $-\mathbf{2 7 6}$

6.3 Australien -277

6.4 Belgien $-\mathbf{2 7 7}$ 
6.5 China -278

6.6 Frankreich -279

6.6.1 Couffignals Misserfolg -279

6.6.2 SEA $-\mathbf{2 8 0}$

6.6.3 Bull mit Gamma -280

6.7 Indien -280

$6.8 \quad$ Israel -280

6.9 Italien $-\mathbf{2 8 1}$

6.9.1 Internationales Rechenzentrum der Unesco - $\mathbf{2 8 1}$

6.9.2 Mailand und Pisa -282

6.10 Japan -283

$6.11 \quad$ Kanada -283

$6.12 \quad$ Mexiko -283

$6.13 \quad$ Niederlande -284

6.14 Österreich -284

6.14.1 System Tauschek -284

6.14.2 Mailüfterl 285

6.15 Russland - 286

6.16 Schweden - 288

6.16.1 Relaisrechner Bark - 288

6.16.2 Wer betrieb Bark? - 288

6.16.3 Elektronenrechner Besk -290

6.17 Spanien - 291

6.17.1 Analogrechner von Torres Quevedo - 292

6.17.2 Schachautomaten von Torres Quevedo - 292

6.17.3 Analytische Maschine von Torres Quevedo - 295

6.17.4 Formale Sprache - 296

6.18 Vereinigte Staaten von Amerika (USA) -297

6.18.1 Patent- und Urheberrechtsstreit -297

6.18.2 Die ersten amerikanischen Digitalrechner (Übersicht) — 298

6.18.3 Schweizer Vorfahren von Eckert und Mauchly —299

7 Wörterverzeichnis zur Technikgeschichte (D-E) - 303

7.1 Deutsch-Englisch $-\mathbf{3 0 4}$

8 Wörterverzeichnis zur Technikgeschichte (E-D) - 479

8.1 Englisch-Deutsch $-\mathbf{4 7 9}$

Bibliografie zur Technik- und Naturwissenschaftsgeschichte -661

Personen-, Orts- und Sachverzeichnis - 1023 


\section{Wer hat den Computer erfunden?}

Zusammenfassung: Zunächst geht es im Kapitel „Wer hat den Computer erfunden?“ um die Klärung von Begriffen wie Algorithmus, Compiler, Computer, Turingmaschine, Universalrechner, selbstveränderliches Programm, Speicherprogramm und Von-Neumann-Rechner. Erörtert werden ferner manche Streitfragen: Wer hat wann und wo den Von-Neumann-Rechner, den Computer und den Compiler erfunden? Von wem stammen das Speicherprogramm und die automatische Programmierung? Wie groß war Turings Einfluss auf den Rechnerbau? War Ada Lovelace wirklich die erste Programmiererin? Welches waren die maßgeblichen frühen Veröffentlichungen zum Rechnerbau und zur Programmierung? Was für Pionierinnen und Pioniere stecken hinter den Errungenschaften? Der Computer hatte zahlreiche Schöpfer in mehreren Ländern und auch zahlreiche Vorläufer. Beim Rechnerbau kam es natürlich auch zu Misserfolgen. Manche messen der Priorität, z.B. beim speicherprogrammierten Rechner, eine hohe Bedeutung zu. Eine Zusammenstellung zählt frühe Relais- und Röhrenrechner in Europa und den USA sowie ihre Nachfolgemaschinen auf. Zur Sprache kommen einflussreiche Rechenautomaten. Ferner werden die ersten marktfähigen Computer vorgestellt. Erwähnt werden auch aufkommende europäische und US-amerikanische Transistorrechner. Eine Zeittafel gibt Auskunft über frühe mechanische und elektronische Digitalrechner aus den Vereinigten Staaten, Australien und Europa. Eine Liste ausgewählter Jubiläen zur Geschichte der Rechentechnik rundet das Kapitel ab.

Schlüsselwörter: ABC, Algorithmus, automatische Programmierung, Charles Babbage, Compiler, Presper Eckert, Eniac, Erfindung des Computers, Kurt Gödel, Harvard Mark, Ada Lovelace, John Mauchly, Priorität, Speicherprogramm, Alan Turing, Turingmaschine, Univac, Universalrechner, John von Neumann, Von-Neumann-Rechner, Konrad Zuse

\subsection{Vorbemerkungen}

In den 1930er Jahren beginnen Konrad Zuse (Deutschland) sowie Howard Aiken, George Stibitz und John Atanasoff (USA) mit dem Bau digitaler Relais- und Röhrenrechner. Alan Turing (England) macht sich Gedanken zu einer universellen Turingmaschine. Brauchbare Geräte erscheinen ab den 1940er Jahren. Der Ausdruck „Computer“ im heutigen Sinn war noch nicht geläufig, Computer waren damals rechnende Menschen.

Wer hat nun was wann erfunden? Für die Nachwelt, besonders die Nutzerinnen und Nutzer, ist im Grunde entscheidend, dass eine wegweisende Erfindung gemacht wurde. Urheber und Zeitpunkt sind für sie weniger wichtig. Darüber gehen die Auffassungen ohnehin häufig auseinander. Für die Beteiligten sieht die Sache natürlich 
anders aus (Patentrecht). Noch heute werden die Begriffe „Computer“, „Turingmaschine“ und „Von-Neumann-Rechner“ unterschiedlich ausgelegt.

Es war ein langer Weg von den mechanischen zu den elektronischen Rechnern (vgl. Tab. 1.1).

Tab. 1.1: Vorläufer der Relais- und Röhrenrechner (Auswahl)

\begin{tabular}{|c|c|c|c|}
\hline Merkmal & Erfinder & Land & Jahr \\
\hline erste (mechanische) Rechenmaschine & Wilhelm Schickard & Deutschland & 1623 \\
\hline $\begin{array}{l}\text { erste erhaltene (mechanische) Rechen- } \\
\text { maschine (Zweispeziesmaschine) }\end{array}$ & Blaise Pascal & Frankreich & 1642 \\
\hline erste (mechanische) & Gottfried Wilhelm Leibniz & Deutschland & 1673 \\
\hline \multicolumn{4}{|l|}{ Vierspeziesrechenmaschine } \\
\hline programmierbarer Schreibautomat & Friedrich Knaus & Österreich & 1760 \\
\hline programmierbarer Schreibautomat & Pierre Jaquet-Droz & Schweiz & 1768 \\
\hline mechanischer Webstuhl & Joseph-Marie Jacquard & Frankreich & 1805 \\
\hline analytische Maschine & Charles Babbage & England & 1834 \\
\hline erste Tastenrechenmaschine & Luigi Torchi & Italien & 1834 \\
\hline erster erhaltener Tastenaddierer & Jean-Baptiste Schwilgué & Frankreich & 1844 \\
\hline erste Lochkartenanlage & Herman Hollerith & USA & 1890 \\
\hline $\begin{array}{l}\text { programmgesteuerte } \\
\text { elektromechanische Rechenmaschine }\end{array}$ & Leonardo Torres Quevedo & Spanien & 1920 \\
\hline
\end{tabular}

(C) Bruderer Informatik, CH-9401 Rorschach 2020

\section{Anmerkungen}

Der Rechenrahmen (Kugelrechner) gilt nicht als Rechenmaschine. Die schickardsche Rechenuhr hatte getrennte Rechenwerke für die Addition und die Subtraktion bzw. die Multiplikation und die Division (nepersche Einmaleinswalzen). Du Bois Parmelee (USA) erhielt 1850 ein Patent für seine Tastenrechenmaschine. Victor Schilt (Schweiz) fertigte 1850 einen (erhaltenen) Nachbau des schwilguéschen Geräts an. Von Schwilgués Maschine sind neben Vorläufern zwei Exemplare (1844 und 1851) bekannt. Vor der Einführung der Maschinen mit Tastenantrieb hatten die Einstellwerke Schieber, Drehscheiben $\mathrm{u}$. dgl.

Die beiden Maschinen von Schickard gingen verloren, von Leibniz ist nur ein (einziges) späteres Gerät bewahrt. Torchis Tastenmaschine ist nicht überliefert. Von der Pascaline sind noch mehrere Ausführungen vorhanden. Charles Babbage (England) hat weder seine Differenzen- noch seine analytische Maschine vollendet. 


\subsection{Was ist ein Computer?}

Die Ansichten der Fachleute über das Wesen des Computers gehen weit auseinander. Erwartungsgemäß gibt es viele unterschiedliche Umschreibungen. Hinzu kommt, dass sich die Bedeutung des Begriffs „Computer“ im englischsprachigen Raum je nach dem Stand der technischen Entwicklung mehrfach verändert hat. Der Bedeutungswandel erstreckt sich vom rechnenden Menschen über analoge und digitale, mechanische und elektronische Rechenmaschinen $\mathrm{zu}$ programmgesteuerten und speicherprogrammierten Rechenautomaten. Von wenigen raumfüllenden Riesenrechnern (meist Einzelanfertigungen) ging es zu einer unüberschaubaren Masse von leichten, tragbaren, allgegenwärtigen Vielzweckgeräten und zu einer ungeheuren Menge von verborgenen winzigen Spezialeinrichtungen, die in Dinge aller Art eingebaut sind.

Im deutschen, französischen, italienischen und spanischen Sprachraum waren Rechner, calculateur/calculatrice, calcolatore/calcolatrice und calculador ursprünglich ebenfalls Menschen. Heute werden unter „Rechnern“ üblicherweise Maschinen verstanden. Die Wende setzte erst in der zweiten Hälfte des 20. Jahrhunderts ein. Lange Zeit unterschied man auch zwischen datenverarbeitenden und technisch-wissenschaftlichen Rechenanlagen. Die Datenverarbeitung spielte beispielsweise in der Statistik und der Buchhaltung eine erhebliche Rolle. In den frühen angelsächsischen Schriften finden sich neben „computer“ auch Ausdrücke wie „computing machine“, „calculator“ und „calculating machine“. Der Gebrauch ist jedoch uneinheitlich.

Die Bezeichnung „Computer“ wird in dieser Arbeit in einem weiten Sinn verwendet. Darunter fallen bestimmte analoge sowie digitale, mechanische, elektromechanische und elektronische Rechner, Relais-, Röhren- wie auch Transistormaschinen, festprogrammierte, stecktafelgesteuerte, programmgesteuerte und speicherprogrammierte Geräte. Weil die Vielfalt dieser Rechenhilfsmittel groß ist, gibt es nicht nur einen einzigen, sondern mehrere Erfinder des Computers.

\subsection{Was ist eine Turingmaschine?}

Im Folgenden finden Sie einige Gedanken zu der für Laien ziemlich schwer verständlichen Turingmaschine.

\subsubsection{Aufbau der Turingmaschine}

Eine Turingmaschine ist ein mathematisches Modell einer (idealisierten, universellen) Rechenmaschine. Die Turingmaschine ist ein Gedankenmodell, keine echte Maschine. Alan Turing hat sie in seiner 1936 eingereichten (heute berühmten) Abhandlung „On computable numbers, with an application to the Entscheidungs- 
problem“ vorgestellt. Sie gleicht einem Tonbandgerät. Das Grundmodell besteht aus folgenden Bestandteilen:

- Steuerwerk (Steuereinheit, Schaltwerk),

- Lese-Schreib-Kopf,

- beidseitig unendliches Speicherband.

Das unendlich lange Band ist in Felder (Zellen) eingeteilt. Jede Speicherzelle kann ein (einziges) Zeichen (aus einem Alfabet mit endlich vielen Zeichen) aufnehmen oder leer sein. In einem Feld kann z.B. die Zahl 0 oder 1 stehen. Das „Alfabet“ (Zeichenvorrat) umfasst nicht nur Buchstaben, sondern auch Ziffern.

Ist die Turingmaschine ein Automat? Darüber sind die Meinungen geteilt. Die Antwort hängt von der zugrunde liegenden Begriffsbestimmung ab.

\section{6 waren Rechner Menschen}

„Turing's achievement was to determine not what machines could compute, but what human beings could compute with enough resources of time and space for the computation." (siehe Robert Irving Soare: Turing computability, Springer-Verlag, Berlin, Heidelberg 2016, Seite 238).

Turings Meisterleistung bestand darin zu bestimmen, was Menschen mit ausreichend Zeit und Platz berechnen konnten und nicht, was Maschinen zu berechnen imstande waren.

\subsubsection{Programmablauf}

Das Steuerprogramm (Zustandsänderungstabelle) bestimmt die Handlungen (Lesen, Schreiben, Bewegen, Zustandsänderung) der Turingmaschine. Sie hängen vom jeweiligen Zustand der Maschine und vom Inhalt der Zelle ab. Das Programm legt dabei für jeden Zustand fest, welcher Buchstabe welchen Vorgang auslöst. Nach jeder Handlung kann sich der Zustand der Maschine ändern. Der Lese-Schreib-Kopf liest oder beschreibt jeweils das Feld (Arbeitsfeld, Arbeitszelle), das sich zu diesem Zeitpunkt unter ihm befindet. Er kann den Zellinhalt überschreiben oder unverändert lassen. Das Speicherband (Arbeitsband) lässt sich um ein Feld nach rechts oder links verschieben. Die Steuereinheit kann eine endliche Zahl von Zuständen einnehmen.

Jede Turingmaschine entspricht einer bestimmten Rechenvorschrift (Algorithmus). Diese ist dann berechenbar, wenn die zugehörige Turingmaschine nach endlich vielen Schritten anhält.

Dank der Turingmaschine lassen sich grundlegende Erkenntnisse über die Fähigkeiten von Rechenmaschinen (Berechenbarkeit, Entscheidbarkeit) gewinnen. Der Amerikaner Emil Leon Post hat 1936 ein gleichwertiges mathematisches Modell erar- 
beitet, auch Alonzo Church (USA) hat eine vergleichbare Untersuchung durchgeführt. Posts (gedankliche) universelle Maschine hat sich aber nicht durchgesetzt.

\subsubsection{Bedeutung für die theoretische Informatik}

Der Turingmaschine kommt in der theoretischen Informatik eine grundlegende Bedeutung zu. Ihr Schöpfer hat gezeigt, dass es Aufgabenstellungen gibt, die mit Rechenverfahren (Algorithmen) nicht lösbar, d.h. nicht entscheidbar sind. Als Beispiele werden das hilbertsche Entscheidungsproblem (Untersuchung, ob eine Formel der Prädikatenlogik allgemein gültig ist) und das Halteproblem (Frage, ob die Ausführung eines Algorithmus endlos lange verläuft, ob die Turingmaschine jemals zum Stillstand kommt) angeführt.

Alle Berechnungen, die auf einem derzeitigen Computer, z.B. einem Von-Neumann-Rechner, durchführbar sind, können nach der Church-Turing-These auch auf der Turingmaschine ausgeführt werden. Es handelt sich hier um eine durch die Erfahrung bestätigte Annahme. Sämtliche bisher bekannten sinnvollen Berechnungsmodelle und Rechner sind gleich mächtig wie die Turingmaschine. Diese kann einen Von-Neumann-Rechner nachahmen (simulieren). Eine Aufgabe lässt sich genau dann berechnen, wenn sie sich durch eine Turingmaschine bewältigen lässt. Eine Datenverarbeitungsanlage gilt als turingmächtig (turingvollständig), wenn sie universell (d.h. frei) programmierbar ist.

Die Turingmaschine ist Gegenstand der Berechenbarkeitstheorie (Welche Probleme lassen sich grundsätzlich algorithmisch lösen? Welche Funktionen lassen sich automatisch berechnen?) und der Komplexitätstheorie (Wie hoch sind der Aufwand an Rechenzeit und der Speicherbedarf, um eine Fragestellung zu lösen? Ist die Aufgabe mit vertretbarem Aufwand praktisch lösbar?).

Die Turingmaschine ist überdies bedeutsam für die Automatentheorie (Wie verhält sich die abstrakte Maschine, wie ist das mathematische Modell aufgebaut?) und die Theorie der formalen Sprachen (z.B. Programmiersprachen). Sie eignet sich für das Beweisen von Behauptungen algorithmischer Art.

\subsubsection{Algorithmus}

Ein Grundbegriff der Informatik ist der Algorithmus. Ein Algorithmus lässt sich etwa so umschreiben:

- Anleitung zur Lösung einer Aufgabe; Verfahren zur Lösung eines Problems; Lösungsverfahren; Verarbeitungsvorschrift; Verfahrensregel; Rechenvorschrift; Rechenverfahren;

- endliche Folge von allgemein(gültig)en, eindeutigen, ausführbaren Anweisungen (Arbeitsschritten). 
Der Fachbegriff ist nach dem persischen Mathematiker Muhammad Ibn Musa Al Chwarismi, Verfasser eines Werks über Rechenregeln (etwa 780 bis 850 n.Chr.), benannt.

Beispiele aus dem Alltag sind Kochrezept, Bastelanleitung, Spielregeln, Gebrauchsanweisung, Partitur, Schnittmuster.

\section{Babylonische und griechische Algorithmen}

Die ersten bekannten schriftlichen Algorithmen wurden um 2000 v. Chr. im Zweistromland (Mesopotamien) geschaffen (siehe Donald E. Knuth; Luis Trabb Pardo: The early development of programming languages, in: Donald E. Knuth (Hg.): Selected papers on computer languages, Center for the study of language and information, Stanford 2003, Seite 4, sowie Donald E. Knuth: Ancient Babylonian algorithms, in: Communications of the ACM, Band 15, 1972, Heft 7, Seiten 671-677, und Band 19, 1976, Heft 2, Seite 108).

$\mathrm{Zu}$ den klassischen Algorithmen gehören:

- das sumerisch-babylonische Wurzelziehen (Verfahren zur Lösung quadratischer Gleichungen, Kodex Hammurapi (Rechtssammlung), um 1700 v. Chr.),

- der euklidische Algorithmus (Verfahren zur Ermittlung des größten gemeinsamen Teilers; Euklid von Alexandria, 4. Jh. v. Chr.),

- das Sieb des Eratosthenes (Verfahren für die Bestimmung von Primzahlen; Eratosthenes von Kyrene, 3. Jh. v. Chr.),

- die Annäherung der Kreiszahl $\pi \pi$ (Archimedes von Syrakus, 3. Jh. v. Chr.) und

- das Heron-Verfahren (Heron von Alexandria, 1. Jh. n. Chr.).

Ein weit verbreitetes Rechenverfahren wird schon im Papyrus Rhind (um 1550 v. Chr.) festgehalten: die ägyptische Multiplikation. Sie entspricht der äthiopischen und der russischen Multiplikation. Das vom Schriftgelehrten Ahmose verfasste äußerst wertvolle Dokument enthält 84 mathematische Aufgaben. Es ist nach dem schottischen Anwalt Alexander Henry Rhind benannt und befindet sich im British Museum, London. Das Dokument wurde Mitte des 19. Jahrhunderts in Ägypten gefunden.

Erst 2013 fand Menso Folkerts Jost Bürgis „Kunstweg“ (1592). Über 400 Jahre lang war Bürgis Verfahren zur Berechnung von Sinuswerten ein Rätsel.

Für weitere Angaben vgl.

Jochen Ziegenbalg; Oliver Ziegenbalg; Bernd Ziegenbalg: Algorithmen von Hammurapi bis Gödel,

Springer Fachmedien, Wiesbaden, 4., überarbeitete und erweiterte Auflage 2016, Seiten 55-85.

\subsubsection{Universalmaschine}

„These postwar machines were designed to be all-purpose universal devices capable of carrying out any symbolic process whatever, so long as the steps in the process were specified precisely. Of course, some processes may require more memory than is available or may simply take too long to be feasible, so these machines can only be approximations to Turing's idealized universal 
machine. Nevertheless it was crucial that they had a large „memory“ (corresponding to Turing's infinite tape) in which instructions and data could coexist. This fluid boundary between what was instruction and what was data meant that programs could be developed that treated other programs as data. In early years, programmers mainly used this freedom to produce programs that could and did modify themselves. In today's world of operating systems and hierarchy of programming languages, the way has been opened to far more sophistic applications. To an operating system, the programs that it launches (e. g. your word processor or e-mail program) are data for it to manipulate, providing each program with its own part of the memory [...]. Compilers translate programs written in one of today's popular programming languages into the underlying instructions that can be directly executed by the computer: for the compiler these programs are data." (siehe Martin Davis: The universal computer, CRC press, Boca Raton, Florida, London usw. 2012, Seiten 164-165).

Diese Nachkriegsmaschinen wurden als universelle Allzweckgeräte ausgestaltet. Sie konnten jeden beliebigen symbolischen Prozess ausführen, sofern die Verfahrensschritte genau festgelegt waren. Natürlich erfordern gewisse Vorgänge mehr Speicher als verfügbar ist oder dauern übermäßig lang. Daher können diese Maschinen nur Annäherungen an die idealisierte universelle Turingmaschine darstellen. Dennoch war es entscheidend, dass sie einen großen Speicher hatten (entsprechend Turings unendlichem Band), in dem gleichzeitig sowohl Anweisungen als auch Daten abgelegt sind. Diese fließende Grenze zwischen Befehlen und Daten bedeutete, dass man Programme entwickeln konnte, die andere Programme als Daten behandelten. In der Frühzeit nutzten Programmierer diese Freiheit hauptsächlich, um Programme zu schreiben, die sich selbst verändern konnten. In der heutigen Welt der Betriebssysteme und der Rangordnung der Programmiersprachen sind viel anspruchsvollere Anwendungen möglich. Für ein Betriebssystem stellen die Programme (z.B. für die Textverarbeitung oder die elektronische Post), die es aufruft, Daten dar, die sich verarbeiten lassen. Dabei wird jedem Programm ein eigener Speicherplatz zur Verfügung gestellt [...]. Compiler (Übersetzer) übertragen Programme, die in einer der heute gängigen Programmiersprachen geschrieben sind, in die zugrunde liegenden Anweisungen. Der Rechner kann diese unmittelbar ausführen, denn für den Compiler sind diese Programme Daten.

\section{Anmerkung}

$\mathrm{Zu}$ Beginn waren selbst speicherprogrammierte Maschinen nur teilweise universell. Es gab nämlich Anlagen für die kaufmännische Datenverarbeitung und das wissenschaftliche Rechnen.

Im Zusammenhang mit dem Speicherprogramm tauchen die Namen Gödel, Turing und von Neumann (vgl. Abb. 1.1) auf. 


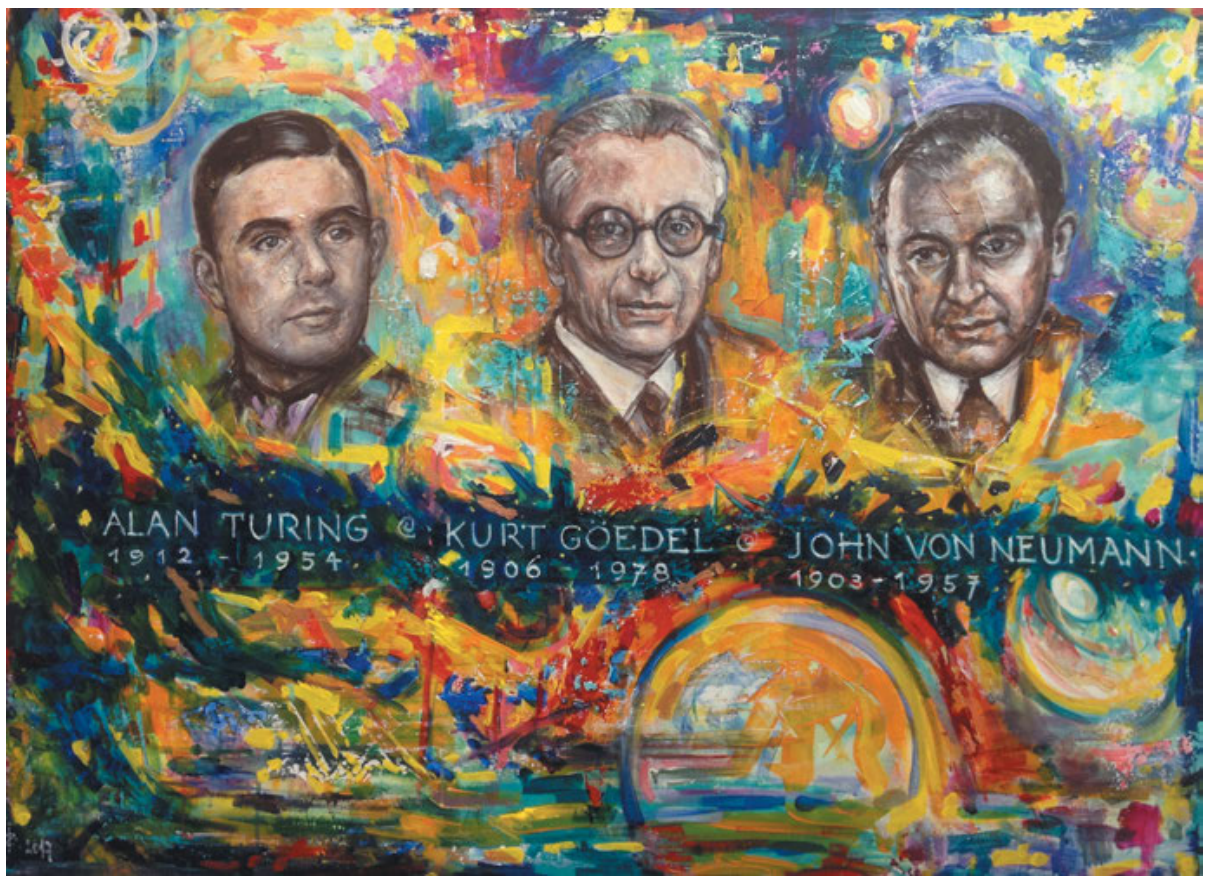

Abb. 1.1: Turing, Gödel und von Neumann. Alan Turing, Kurt Gödel und John von Neumann haben die theoretischen Voraussetzungen für den Rechnerbau geschaffen (@ Ingrid Zámečníková, Bratislava).

\subsection{Was ist ein Von-Neumann-Rechner?}

\subsubsection{Aufbau eines Von-Neumann-Rechners}

John von Neumann und seine Mitarbeiter beschreiben in ihren Abhandlungen von 1945 und 1946 die grundlegende Gestaltung eines Universalrechners.

Ein Von-Neumann-Rechner besteht aus fünf Einheiten, die miteinander über Datenpfade (Datenwege, Datenkanäle) verbunden sind:

- Steuerwerk (Leitwerk),

- Rechenwerk,

- Speicherwerk (Speicher),

- Eingabewerk,

- Ausgabewerk.

Neben dem internen Kurzzeitspeicher (Hauptspeicher oder Arbeitsspeicher) gibt es auch externe Langzeitspeicher (Massenspeicher, Zusatzspeicher).

Die Von-Neumann-Bauweise gilt auch heute noch als wegweisend (vgl. Kasten). 


\section{Von-Neumann-Rechner}

Wichtige Merkmale der Von-Neumann-Bauweise sind:

- Der Aufbau des Rechners ist unabhängig von den zu lösenden Aufgabenstellungen. Programme sind auswechselbar, die Geräte werden dadurch zu Vielzweckmaschinen.

- Die Daten (Ausgangswerte, Zwischenergebnisse, Endwerte) und die Programme (Anweisungen) werden im gleichen Speicher (Hauptspeicher) abgelegt.

- Der Hauptspeicher (Arbeitsspeicher) ist in gleich große Speicherzellen unterteilt. Der Zugriff zu den einzelnen, fortlaufend benummerten Speicherstellen erfolgt über ihre Adresse (Nummer).

- Aufeinander folgende Befehle stehen in aufeinanderfolgenden Speicherzellen. Das Steuerwerk spricht den nächsten Befehl an, indem es die Befehlsadresse um Eins erhöht.

- Daten und das Programm können von der Rechenmaschine während der Laufzeit verändert werden.

- Dank Sprungbefehlen (bedingter Sprung) kann die Abarbeitung des Programms je nach Zwischenergebnis bei einem von zwei möglichen Befehlen fortgesetzt werden.

- Für die interne Verarbeitung der Daten, Anweisungen (Befehle) und Adressen wird das Zweiersystem (Binärsystem, Dualsystem) verwendet.

\section{Anmerkungen}

Ein Von-Neumann-Rechner ist ein Vielzweckrechner mit gespeichertem Programm. Charles Babbage plante in den 1830er Jahren einen programmierbaren Universalrechner. Für die Steuerung seiner analytischen Maschine war aber nicht ein inneres, sondern ein äußeres Programm vorgesehen. Er dachte auch an Sprungbefehle. Alan Turing wird neben von Neumann ebenfalls als Schöpfer des Speicherprogramms genannt. Auch Konrad Zuse nutzte das Dualsystem, das u.a. schon Gottfried Wilhelm Leibniz vorgeschlagen hatte. Mehr zu den veränderlichen Programmen im Abschnitt 1.7.6.

Turing und von Neumann hatten unterschiedliche Vorstellungen von der zweckmäßigen Bauweise von Elektronenrechnern (vgl. Tab. 1.2).

Tab. 1.2: Vorstellungen von Alan Turing und John von Neumann im Vergleich

\begin{tabular}{|c|c|c|}
\hline \multicolumn{3}{|c|}{ Gegenüberstellung der speicherprogrammierten Rechner Edvac und Ace } \\
\hline Rechner & Edvac & Ace \\
\hline Schöpfer & John von Neumann & Alan Turing \\
\hline Verhältnis zwischen & Unterscheidung zwischen & Gleichbehandlung von Befehlen und \\
\hline Befehlen und Zahlen & Befehlen und Zahlen & Zahlen \\
\hline Befehlsänderung & beschränkte Befehlsänderung & unbeschränkte Befehlsänderung \\
\hline Programmierbarkeit & einfachere Programmierung & schwierigere Programmierung \\
\hline Einfluss & viele Nachfolgemaschinen & wenige Nachfolgemaschinen \\
\hline
\end{tabular}




\subsection{Ist der Von-Neumann-Rechner eine Serien- oder eine Parallelmaschine?}

Der Engpass beim Datenaustausch zwischen dem Steuerwerk, dem Rechenwerk und dem Hauptspeicher wird als „Von-Neumann-Flaschenhals“ bezeichnet. Der Verkehr läuft über einen (einzigen) Datenpfad, was zu einem Stau führen kann. Demnach sind Von-Neumann-Maschinen Serienrechner (mit einem einzigen Rechen- und Steuerwerk). Nach einer abweichenden Auffassung gelten Von-Neumann-Maschinen jedoch als Parallelrechner.

Ursache der Verwirrung sind wohl die beiden unterschiedlichen Ausprägungen der Eniac-Nachfolger:

- Bei dem an der Moore school of electrical engineering der Universität von Pennsylvania in Philadelphia entwickelten Röhrenrechner Edvac (1952) handelt es sich um eine Serienmaschine (mit Quecksilberspeicher).

- Im Unterschied dazu wurde am Institute for advanced study in Princeton ein elektronischer Parallelrechner namens IAS-Rechner oder Princetonmaschine (1952, mit elektrostatischem Speicher) gebaut.

Die Antwort auf die Frage „Ist der Von-Neumann-Rechner eine Serien- oder eine Parallelmaschine?“ fällt unterschiedlich aus. Je nachdem, ob man sich auf den Rechner von Philadelphia oder von Princeton bezieht, liegt eine Serien- oder Parallelmaschine vor.

Beide Maschinen wurden als Modellrechner betrachtet und mehrfach nachgebaut. Von Neumann war an zwei Orten tätig, in Philadelphia als Berater und in Princeton als Forscher. Die Herstellung des Serienrechners Edvac war technisch einfacher. Die Fertigung der parallelen, schnelleren IAS-Maschine war anspruchsvoller. Bei beiden Anlagen kam es zu Verzögerungen. Philadelphia litt unter häufigem Personalwechsel. In Princeton machte die ursprünglich vorgesehene Selectron-Speicherröhre Bauchweh. Sie war schließlich in den frühen 1950er Jahren verfügbar und wurde von Rand verwendet (Rechner Johnniac).

\subsection{Wer hat den Von-Neumann-Rechner erfunden?}

Es waren vor allem zwei Schriften, die den (logischen) Aufbau von Rechnern nachhaltig prägten:

- John von Neumann: First draft of a report on the Edvac (1945) und

- Arthur Walter Burks; Herman Heine Goldstine; John von Neumann: Preliminary discussion of the logical design of an electronic computing instrument (1946). 
Kennzeichen der beiden Maschinen - Edvac und IAS-Rechner (Princetonmaschine) waren das Speicherprogramm und die Nutzung des Dualsystems. Das erste Gerät war wie erwähnt ein Serienrechner, das zweite ein Parallelrechner.

Eine Gliederung von Rechenmaschinen in mehrere Funktionseinheiten gab es schon früher, u.a. bei Herons Automaten und auch bei Figurenautomaten:

Die programmierbaren aufziehbaren Schreibautomaten von Friedrich Knaus (1760) und Pierre Jaquet-Droz (1772), die (mit gewissen Einschränkungen) einen beliebigen kurzen Text in Handschrift aufsetzen konnten, nutzten eine Gänsefeder für die Ausgabe, hatten einen Speicher für die Buchstaben bzw. die Wörter und ein Steuerwerk. Die Eingabe geschah über eine Stiftwalze bzw. eine Nockenscheibe.

Auch Charles Babbage hatte für seine analytische Maschine (1834) mehrere Baueinheiten vorgesehen: Rechenwerk (Mühle), Steuerwerk, Speicherwerk, Eingabeeinheit, Ausgabeeinheit.

Ähnlich Leonardo Torres Quevedo. Seine elektromechanische Rechenmaschine (1920) nutzte für die Ein- und Ausgabe eine Schreibmaschine.

Konrad Zuse schuf für seinen Relaisrechner Z3 (1941) einen vergleichbaren Aufbau.

Ist der Begriff ,Von-Neumann-Rechner“ zutreffend?

Die meisten modernen Computer sind so genannte Von-Neumann-Rechner. Die Bezeichnung ist allerdings umstritten, denn von Neumann war nicht der alleinige Urheber. Die Auseinandersetzung betrifft insbesondere die Speicherprogrammierung. Von Neumann verhalf aber diesem Konzept zum Durchbruch. Mehr dazu in den Abschnitten 1.9 und 6.18.1.

\subsection{Was bedeutet Speicherprogramm?}

\subsubsection{Gespeicherte Programme sind nichts Neues}

Schon im Altertum und im Mittelalter waren gespeicherte Programme gang und gäbe, z.B. beim Automatentheater des Heron von Alexandria. Die programmierbare Schnurwicklung um eine mit Zapfen versehene Trommel legte den Ablauf des Schauspiels fest. Die Art der Schnurführung um die Pflöcke bestimmte die Drehrichtung der Walze.

Programmwalzen sind auch bei Ibn al Razzāz al-Jazarī und Athanasius Kircher (Wasserorgel) zu finden. Die Wasserorgel (eine mit Wasserkraft (Wasserrad) angetriebene Orgel) von Salomon de Caus ist mit einer Stiftwalze ausgestattet. Ihr Musikrad (musikalisches Steinrad) ist mit einem Papierband versehen. In ähnlicher Weise arbeiten Glockenspiele und Walzenspieldosen. Eine andere Form der Programmspeicherung nutzen die Figurenautomaten der Jaquet-Droz, nämlich Trommeln mit Kurvenscheiben. Lochstreifen steuern Webmaschinen. Lochplatten sind die Program- 
mträger bei Scheibenspieldosen. Nocken legten die Fahrrichtung des mechanischen Wagens von Leonardo da Vinci fest.

\subsubsection{Daten und Programm im gleichen Speicher}

Bei speicherprogrammierten Rechnern sind nicht nur die Daten, sondern auch die Programme im gleichen Speicher (Haupt- oder Arbeitsspeicher) abgelegt. Anweisungen werden gleich behandelt wie die Daten. Damit lassen sich nicht nur die Informationen, sondern auch die Rechenbefehle mit vergleichsweise kleinem Aufwand ändern. Anwendungen können ohne weiteres ausgetauscht werden. Im Gegensatz dazu mussten bei schalttafelgesteuerten Geräten die Kabelverbindungen jeweils für neue Aufgabenstellungen umgesteckt werden, was umständlich und langwierig war. Es gab allerdings auch auswechselbare Steckbretter. Programme auf Lochkarten oder Lochstreifen sind im Gegensatz zu den im Arbeitsspeicher abgelegten Anweisungen schwer zu verändern.

Üblicherweise werden Daten und Programme im gleichen internen Speicher abgelegt. In Frage kommen aus heutiger Sicht auch externe Hochgeschwindigkeitsspeicher. Entscheidend ist, dass die Programme in einen Speicher geladen und von diesem aus durch das Rechenwerk ausgeführt werden können. Die Anweisungen können überdies auf unterschiedlichen Speichern gehalten werden. Das wurde etwa bei den Harvard-Rechnern so gehandhabt.

„Die Fähigkeit des speicherprogrammierten Rechenautomaten, sein Programm selbsttätig zu modifizieren und logische Entscheidungen $\mathrm{zu}$ treffen, unterschied Anlagen dieser Struktur grundsätzlich von jedem starren Automaten und war mitentscheidend für seine heutige Bedeutung.“ (siehe Karl Ganzhorn; Wolfgang Walter: Die geschichtliche Entwicklung der Datenverarbeitung, IBM Deutschland, Stuttgart 1975, Seite 54).

Die Befehlsspeicherung auf Lochstreifen (oder auch Magnetbändern), d.h. auf äußeren Speichern, bremste den Rechenbetrieb. Das Auslesen der Anweisungen und die Suchzeit für Sprungbefehle beanspruchten viel Zeit. Beim Einsatz einer Magnettrommel (wie bei Harvard mark 3) ließ sich dieser Nachteil weitgehend beheben.

\footnotetext{
„Diese Art der Befehlsspeicherung [Befehle im Zahlenspeicher, d.h. Befehle und Zahlen im gleichen Speicher] gewährleistet eine gute Ausgeglichenheit der Rechenzeiten, der Suchzeiten für die Befehle und der für einen Sprung benötigten Zeit; ferner bieten sich dem Mathematiker bedeutende Möglichkeiten in der Planfertigung [...]. Dagegen wird der Rechenprozeß etwas verlangsamt, weil dem Speicher nach jeder Operation ein neuer Befehl entnommen werden muß.“ (siehe Heinz Rutishauser; Ambros Speiser; Eduard Stiefel: Programmgesteuerte digitale Rechengeräte (elektronische Rechenmaschinen), Birkhäuser Verlag, Basel 1951, Seite 92).
}

Die Trennung von Befehls- und Zahlenspeicher erwies sich in der Praxis als unzweckmäßig. Denn manche Aufgaben erfordern viele unterschiedliche Rechenvorgänge für 
wenige Daten (z.B. Bestimmung der Zahl $\pi$ ). In anderen Fällen werden wenige Vorgänge auf eine Fülle von Daten angewandt (z.B. kaufmännische Lösungen). Das Wort Plan steht für Rechenplan (Rechenprogramm).

\subsubsection{Rechner ohne und mit Programmspeicher}

In der Frühzeit der Informatik sprach man von:

- Rechenautomaten ohne Befehlsspeicher

Anweisungen werden direkt vom Befehlsstreifen (Lochstreifen) abgelesen und ausgeführt. Für jeden Unterplan (Unterprogramm) ist ein eigener Befehlsstreifen erforderlich. Die Anzahl der nutzbaren Unterprogramme ist von der Menge der verfügbaren Lochstreifenlesestationen abhängig. Mit Sprungbefehlen hüpft man jeweils zu anderen Unterprogrammen und damit zu einem anderen Abtaster.

„Ein Sprungbefehl bewirkt entweder das Weiterlaufen des Streifens ohne Ausführung der dabei durchlaufenen Befehle und Wiedereinsetzen bei einem späteren Befehl oder dann den Übergang auf einen anderen Befehlsstreifen.“ (siehe Heinz Rutishauser; Ambros Speiser; Eduard Stiefel: Programmgesteuerte digitale Rechengeräte (elektronische Rechenmaschinen), Birkhäuser Verlag, Basel 1951, Seite 19).

- Rechenautomaten mit Befehlsspeicher

Anweisungen werden vom Befehlsstreifen (Lochstreifen) abgetastet und in den Befehlsspeicher übertragen.

„Jede Zelle des Befehlsspeichers enthält dann einen Befehl. Ein in die Maschine eingebauter Befehlszähler [...] ruft nun die einzelnen Zellennummern in ihrer natürlichen Reihenfolge auf; der in der Zelle enthaltene Befehl wird abgelesen und vom Leitwerk ausgeführt. [...]. Im Falle von bedingten Sprungbefehlen muß auch das Rechenwerk den Stand des Befehlszählers beeinflussen können. Diese Organisation der Maschine erlaubt ein sehr flexibles Springen von einer Befehlsreihe zur andern.“ (siehe Heinz Rutishauser; Ambros Speiser; Eduard Stiefel: Programmgesteuerte digitale Rechengeräte (elektronische Rechenmaschinen), Birkhäuser Verlag, Basel 1951, Seite 19).

Die Anzahl der zulässigen Anweisungen ist durch das Leistungsvermögen des inneren Speichers begrenzt. Mit Sprungbefehlen gelangt man jeweils zu einer bestimmten Anweisung, d.h. zur Speicherzellennummer des nächsten auszuführenden Befehls.

\subsubsection{Voraussetzungen für die Programmspeicherung}

Voraussetzung, um das Programm im (internen) Arbeitsspeicher zu halten, waren leistungsfähige Speicher. Sie war 1941 nicht erfüllt, als Zuse seinen Relaisrechner 
Z3 vorführte. Die Relaismaschinen Complex computer/Bell-Rechner 1 (1939) und Harvard mark 1/IBM ASCC (1944) wie auch die Röhrenrechner ABC (1942), Colossus (1943) und Eniac (1946) hatten keinen inneren Programmspeicher. Die Lage verbesserte sich allmählich ab 1947 mit der Einführung von Quecksilberlaufzeitspeichern, Kathodenstrahlröhrenspeichern (elektrostatische Speicherröhren) und Magnettrommeln. Die ersten (elektronischen) Geräte mit gespeichertem Programm tauchen 1948 auf. Vorher waren die Anweisungen fest verdrahtet oder extern auf Lochkarten, Lochstreifen und Steckbrettern abgelegt.

\subsubsection{Schnellere Datenverarbeitung dank Programmspeicherung}

Bei lochstreifengesteuerten und vor allem bei stecktafelprogrammierten Rechnern verschlang die Eingabe der Befehlsfolgen viel Zeit. Eniac setzte für neue Anwendungen jeweils eine Umkabelung voraus. Selbst für Harvard mark 1/IBM ASCC wurden kurze Unterprogramme auf einem Schaltbrett ausgesteckt. Dieses Vorgehen mochte für Spezialrechner (z.B. Colossus) angehen. Für „Universalrechner“ wie Eniac war das aber, vor allem bei nur vorübergehend benutzten Problemlösungen, ein lästiger Flaschenhals. Bei Lochkartenmaschinen, beispielsweise Rechenlochern, wurden auswechselbare Schalttafeln mit vorgefertigter Verkabelung eingesetzt. Man konnte so wiederkehrende Aufgabenstellungen als fertige Programmbausteine fest verdrahten.

Damit Berechnungen mit hoher Geschwindigkeit durchgeführt werden können, müssen nicht nur die Daten, sondern auch die Anweisungen rasch zur Verfügung stehen. Der Ablauf lässt sich beschleunigen, wenn ein Programm nicht vom (mechanischen) Lochstreifen gelesen und ausgeführt, sondern zunächst in den (elektronischen) Hauptspeicher übertragen und dann abgearbeitet wird. Dafür ist aber ein ausreichender Arbeitsspeicher notwendig.

Eine hohe Rechengeschwindigkeit zwingt zur Programmspeicherung:

\footnotetext{
„Bei einigen neueren Rechenautomaten (Mark III, Binac, Edsac, IAS, Raytheon usw.) ist die Rechengeschwindigkeit zu groß, als daß noch Lochstreifen für die Befehlsgebung in Frage kämen. Man ist deshalb dazu übergegangen, alle Befehle schon vor Beginn der eigentlichen Rechnung in die Maschine einzugeben und dort während der ganzen Rechnung aufzubewahren, sei es, daß wie bei Mark III ein besonderes Befehlsspeicherwerk zur Aufnahme der Befehle vorhanden ist, sei es, daß die Befehle im gleichen Speicherwerk wie die Zahlen aufbewahrt werden“. (siehe Heinz Rutishauser; Ambros Speiser; Eduard Stiefel: Programmgesteuerte digitale Rechengeräte (elektronische Rechenmaschinen), Birkhäuser Verlag, Basel 1951, Seite 53).
}

Nach dieser zeitgenössischen Darstellung aus dem Jahr 1951 waren also langsame externe Programmträger Anlass für die interne Programmspeicherung. Von einem Einfluss Alan Turings ist hier nicht die Rede. 


\title{
1.7.6 Was ist ein selbstveränderliches Programm?
}

Die Speicherprogrammierung ermöglicht selbstveränderliche Programme. Sie waren einst beliebt. Solche Anwendungen sind in der Lage, ihre eigenen Anweisungen während des Ablaufs zu ändern. Bei der Abarbeitung einer Schleife lassen sich die in den Befehlen enthaltenen Speicheradressen anpassen.

„Eine weitere durch die programmgesteuerten Rechenmaschinen realisierte Operation, welche kein Gegenstück beim Arbeiten mit Bürorechenmaschinen hat, ist das Ablesen einer Zahl vom Speicherwerk, deren Adresse zuvor durch die Maschine selbst errechnet wurde. Die Notwendigkeit einer solchen Operation, die für das programmgesteuerte Rechnen von außerordentlicher Bedeutung ist, soll am folgenden Beispiel klargemacht werden. [...]. Werden die Befehle im Zahlenspeicher der Maschine aufbewahrt, so ist die Erhöhung der Adresse relativ einfach: man faßt den abzuändernden Befehl vorübergehend als Zahl auf und addiert zu dieser eine geeignete Konstante. [...]. Falls aber die Maschine mit Lochstreifen gesteuert wird, können natürlich die Befehle nicht abgeändert werden.“ (siehe: Heinz Rutishauser; Ambros Speiser; Eduard Stiefel: Programmgesteuerte digitale Rechengeräte (elektronische Rechenmaschinen), Birkhäuser Verlag, Basel 1951, Seiten 53-54).

Howard Aiken hat erstmals für die Harvard mark 3 (1950) ein i-Register eingeführt. Es kann wie eine gewöhnliche Speicheradresse eine berechnete Zahl aufnehmen. Anstelle einer von vornherein bekannten Adresse kann in einer Anweisung ein besonderes Zeichen eingefügt werden, welches das Steuerwerk veranlasst, die fehlende Adresse aus dem i-Register zu entnehmen.

\begin{abstract}
„Zusammenfassend sei festgestellt, dass die beiden grundsätzlich verschiedenen Verfahren, mit Adressen zu rechnen, zwar praktisch ebenbürtig sind, doch bietet die Verwendung eines $i$-Registers den Vorteil größerer Rechensicherheit, denn es kann nicht bestritten werden, dass das Rechnen mit Befehlen, die als Zahlen aufgefasst werden, ein gewisses Risiko einschließt. Man kann sich leicht vorstellen, dass ein Rechenfehler, der sich beim Rechnen mit Befehlen einschleicht, eine ungleich größere Verwirrung zur Folge hat als ein Rechenfehler beim gewöhnlichen Zahlenrechnen. Es ist dies auch der Grund, warum H. H. Aiken Zahlen und Befehle streng getrennt speichert und das Rechnen mit Befehlen ablehnt, solange nicht die Zuverlässigkeit der zur Verwendung kommenden Schaltelemente ganz erheblich gesteigert werden kann.“ (siehe Heinz Rutishauser; Ambros Speiser; Eduard Stiefel: Programmgesteuerte digitale Rechengeräte (elektronische Rechenmaschinen), Birkhäuser Verlag, Basel 1951, Seiten 55-56).
\end{abstract}

Mit den unzuverlässigen Schaltelementen waren vor allem Relais und Elektronenröhren gemeint. Man unterschied zwischen einem Zahlenspeicher (Datenspeicher) und einem Befehlsspeicher (Programmspeicher). Auf den Zahlenstreifen waren Ausgangswerte, Zwischen- und Endergebnisse abgelegt, auf den Befehlsstreifen Haupt- und Unterprogramme.

Um den Adressteil der Befehle zu ändern, wurden später Indexregister eingeführt. Sie erlauben die Anpassung von Speicheradressen während der Programmausführung. Mit diesem Hilfsmittel muss man nur den Inhalt des Indexregisters, nicht aber 
den Adressteil des zugehörigen Befehls ändern. Das Verfahren wurde erstmals beim Manchester mark 1 (Version vom April 1949 mit zwei Indexregistern) angewandt. Das Patent (1949) wurde auf die Namen Max Newman, Frederic Williams, Thomas Kilburn und Geoff Tootill ausgestellt. Das Indexregister wurde ursprünglich „B-lines“ oder „modifier“ genannt. A stand für Akkumulator, C für Steuerung (control), daher der Buchstabe B (siehe Simon Lavington: Early British computers, Manchester university press, Manchester 1980, Seite 114, und Simon Lavington: A history of Manchester computers, NCC publications, Manchester 1975, Seite 12). Register sind Speicher mit kurzer Zugriffszeit. Sie befinden sich vorzugsweise im Leitwerk.

Früher nutzte man wie erwähnt selbstveränderliche Programme. Heute werden sie vermieden, etwa durch die indirekte Adressierung oder den Aufruf von Unterprogrammen. Bei der indirekten Adressierung verweist man auf eine Adresse, in der die physikalische Adresse aufgezeichnet ist. Erfinder der (patentierten) indirekten Adressierung (1953) ist Heinz Schecher von der (damaligen) Technischen Hochschule München. Die Selbstveränderung hat also nicht mehr den gleichen Stellenwert wie einst, sie ist entbehrlich.

Dazu eine Aussage eines britischen Informatikhistorikers:

„At first great advantage was taken of the consequent ability of a program to read and modify itself during the course of a computation, since such ideas as index registers and indirect addressing had still to be thought of. However of more lasting significance was the subsequent realisation that it would be a practical and attractive proposition to use a computer to assist with the preparation of its own programs, thus opening the way to the development of programming aids such as assemblers, compilers, operating systems, etc.“ (siehe Brian Randell (Hg.): The origins of digital computers, Springer-Verlag, Berlin, Heidelberg usw., 3. Auflage 1982, Seite 375).

Zunächst nutzte man die Fähigkeit eines intern gespeicherten Programms, sich während seiner Abarbeitung selbst zu ändern. Denn Errungenschaften wie Indexregister und indirekte Adressierung waren noch nicht bekannt. Nachher erkannte man, dass sich der Rechner für die Herstellung von Programmen verwenden lässt. Das war von längerfristiger Bedeutung und ermöglichte die Entwicklung von Programmierhilfen wie Assembler [maschinenbezogene Programmiersprache bzw. Programmübersetzer], Compiler [Programmübersetzer], Betriebssysteme usw. Mehr zur automatischen Programmierung in den Abschnitten 1.10 und 4.9.

Randell hält fest:

„This situation led to the realization, probably first in the Eniac/Edvac team at the University of Pennsylvania, of the advantages of storing the program within the computer, in a memory that could be read at electronic speeds during program execution. [...]. However, [...], the concept also has strong connotations of the computer being able to construct, manipulate, and then [...], execute its own programs, all completely automatically. With this latter view, the stored-program concept becomes an engineering approximation to the theoretical universal automaton that Turing had postulated in his (now) famous 1936 paper - that is, a machine which is general-purpose in a very fundamental mathematical sense as well as in a very practical sense. Thus, 
given the practical requirement of replacing the Turing machine's infinite tape by a sufficiently large random access store, it is crucial for the computer to be able to calculate the addresses that are used to access the store, rather than only being able to use precalculated (i. e. fixed) addresses. This, to my mind, is a crucial characteristic of a modern stored-program computer. By these standards the first (1945) design of Edvac does not qualify as a stored program computer. Although data and instructions were to be held in the same store, their representations were quite distinct, and no means were provided for converting data items into instructions. Furthermore, normal arithmetic operations could not be applied to instructions - though the address field of an instruction could be modified. This inadequacy, as we would of course view it, was not present in Turing's proposed design for an automatic computing engine (ACE), which slightly postdated the Edvac report, and was also very quickly remedied in the Edvac design.“ (siehe Brian Randell: The origins of computer programming, in: IEEE Annals of the history of computing, Band 16, 1994, Heft 4, Seite 13).

Dies führte dazu, dass - wahrscheinlich erstmals in der Eniac/Edvac-Gruppe der Universität von Pennsylvania in Philadelphia - die Vorzüge des im Innenspeicher des Rechners abgelegten Programms erkannt wurden. So konnte man während des Programmablaufs den Speicher mit elektronischer Geschwindigkeit lesen. [...]. Der Begriff des (intern) gespeicherten Programms beinhaltet aber meines Erachtens zugleich, dass der Rechner imstande ist, seine eigenen Programme vollautomatisch zu erstellen, zu ändern und auszuführen. Damit wird das Speicherprogrammkonzept zu einer technischen Annäherung an den theoretischen universellen Automaten, den Turing in seinem (nun) berühmten Aufsatz von 1936 vorgeschlagen hat.

Es handelt sich um eine in mathematischer und auch praktischer Hinsicht wegweisende Vielzweckmaschine. Wenn nun das Endlosband der Turingmaschine durch einen ausreichend großen Speicher mit wahlfreiem Zugriff ersetzt wird, muss der Rechner zwangsläufig in der Lage sein, die Speicheradressen zu berechnen, anstatt nur vorgegebene (d.h. feste) Adressen zu nutzen. Meiner Meinung nach ist das ein entscheidendes Merkmal eines modernen speicherprogrammierten Geräts.

Legt man diesen Maßstab zugrunde, entspricht der erste Entwurf für den Edvac von 1945 nicht einem speicherprogrammierten Rechner. Obwohl Daten und Programm im gleichen Speicher gehalten werden, ist ihre Darstellung völlig verschieden. Es wurden zudem keine Mittel für die Umwandung von Daten in Befehle zur Verfügung gestellt. Überdies ließen sich keine gewöhnlichen Rechenvorgänge auf die Anweisungen anwenden, obwohl der Adressteil eines Befehls veränderbar war.

Dieser offensichtliche Mangel kommt in Turings Vorschlag für die Automatic computing engine (Ace) nicht vor, und er wurde im Edvac-Entwurf sehr schnell beseitigt. Turings Schrift erschien kurz nach dem Edvac-Bericht.

Der deutsche Informatiker Friedrich Bauer schreibt:

„Es hat sich eingebürgert, als primäres Merkmal all dieser [speicherprogrammierten] Rechner ihre Eigenschaft anzusehen, daß nicht nur Befehle in einem überschreibbaren Speicher liegen [...], sondern dass Befehle auch während des Programmablaufs durch das Programm selbst abgeändert werden konnten [...]. Das wird heute üblicherweise mit stored program computer 
(„speicherprogrammierter Rechner“) bezeichnet. Man bekommt es fast gratis, wenn man, was eigentlich nicht notwendig wäre, Befehle und Daten im selben (überschreibbaren) Speicher ablegt. Eben diese Idee hatten schon im Januar 1944 die Chefs des Teams, das die Eniac entwickelte, J. Presper Eckert und John W. Mauchly, die sich Gedanken über eine weit leistungsfähigere und weit flexiblere Nachfolgemaschine machten. Im weiteren Verlauf, jedenfalls vor dem 30. Juni 1945 [Erscheinungsdatum des vonneumannschen Edvac-Berichts], hatte Eckert dann die Idee, in der künftigen Edvac Befehle durch die Maschine abändern zu lassen. [...]. Es gibt keinen Grund daran zu zweifeln, dass Eckert und Mauchly das, was später funktionell unter der,vonNeumann-Maschine' verstanden wurde, ausgetüftelt hatten, bevor von Neumann, initiiert durch Herman Goldstine, mit dem Aberdeen Proving Ground und der Moore School Kontakt hatte.“ (siehe Friedrich Bauer: Historische Notizen zur Informatik, Springer-Verlag, Berlin, Heidelberg 2009, Seiten 136-137).

\section{Bauer fügt hinzu:}

„Ironischerweise sind auch Eckert und Mauchly („the program would be stored in exactly the same sort of memory device as that used for numbers“ [das Programm würde in einem gleichartigen Speicher wie die Zahlen abgelegt]) nur die Erfinder eines zahm speicherprogrammierten Rechners" [fortwährende Adressenänderung in einer Schleife in Verbindung mit laufenden Indizes, umgesetzt durch eine Addition im Adressenteil eines Befehls; dadurch konnte man aber nur primitiv-rekursive Funktionen berechnen]. [...]. Von Neumann einerseits, (Eckert und) Mauchly andererseits fanden die ungezähmte Form eines speicherprogrammierten Rechners, die einer universellen Turingmaschine äquivalent ist, sozusagen unfreiwillig. Noch 1946 bzw. 1947 merkten sie anscheinend nicht, was für ein Goldkorn sie mit dem ,stored program concept ${ }^{*}$ gefunden [...] hatten. Es verblieb also Logikern, in den fünfziger Jahren in Strenge die Äquivalenz der speicherprogrammierten Maschine mit der Turing-Maschine zu zeigen, nachdem man dies wohl schon eine Weile stillschweigend unterstellt hatte - einer der ersten publizierten Beweise ist der von Hans Hermes, 1954“ 'Die Universalität programmgesteuerter Rechenmaschinen, in: Mathematisch-physikalische Semesterberichte, Band 4, 1954, Seiten 42-53]. (siehe Friedrich Bauer: Historische Notizen zur Informatik, Springer-Verlag, Berlin, Heidelberg 2009, Seiten 139-141).

\subsubsection{Ist die Turingmaschine selbstveränderlich?}

\section{Der amerikanische Informatikhistoriker Haigh meint zu diesem Thema:}

„Yet while Turing's paper showed one machine could, in modern terms, emulate the functioning of another it never described a machine altering its own instructions. Furthermore, at the very end of the „First draft” von Neumann expressly forbade Edvac from overwriting the operation fields in its instructions, even though he relied on modifications to their address fields to accomplish basic operations such as conditional branching. This address modification was a very influential idea in the „First draft“, but was, of course, absent from Turing's paper as his machines did not use addresses." (siehe Thomas Haigh: Actually, Turing did not invent the computer, in: Communications of the ACM, Band 57, 2014, Heft 1, Seite 41). 
Turing zeigte in seinem Aufsatz, dass eine Maschine (in heutiger Ausdrucksweise) die Arbeitsweise einer anderen nachbilden kann. Er beschrieb aber kein Gerät, das seine eigenen Anweisungen ändert. Zudem verbot von Neumann ganz am Schluss seines Edvac-Berichts das Überschreiben des Operationsfelds von Befehlen ausdrücklich. Dies, obwohl er auf die Änderung des Adressfelds angewiesen war, um grundlegende Vorgänge wie bedingte Sprünge ausführen zu können. Die Adressänderung war ein sehr einflussreicher Gedanke im Edvac-Bericht. Sie fehlte jedoch in Turings Abhandlung, weil seine Maschinen nicht mit Adressen arbeiten.

Ein weiterer Kommentar aus Belgien:

„Turing's universal machine did not modify its own instructions, nor did it modify the instructions of other machines that it simulated.“ (siehe Edgar Graham Daylight: Turing tales, Lonely Scholar, Geel (Belgien) 2016, Seite 4).

Turings universelle Maschine änderte weder ihre eigenen Anweisungen noch die der Maschinen, welche sie nachbildete.

\section{Wird die Rolle der Logik überschätzt?}

„Similarly, the claim that the general-purpose nature of the computer stems from Turing's universal machine concept seems to overstate the role of logic.“ (siehe Mark Priestley: A science of operations, Springer-Verlag, London 2011, Seite 154).

Gleichermaßen scheint die Behauptung, dass die vielfältigen Fähigkeiten des elektronischen Digitalrechners von der universellen Turingmaschine herrühren, die Rolle der Logik zu übertreiben.

„It would oversimplify a complex historical situation to suggest, with Mahoney and Davis, that the stored-program design emerged simply as a byproduct of theoretical research in logic." (siehe Mark Priestley: A science of operations, Springer-Verlag, London 2011, Seiten 136-137).

Man würde eine vielschichtige historische Entwicklung zu stark vereinfachen, wenn man, wie (Michael) Mahoney und (Martin) Davis, behauptet, dass der Gedanke des Speicherprogramms einfach als Nebenprodukt der Forschung in theoretischer Logik aufkam.

„The historical evidence supporting the idea of a direct influence from logic on the idea of the stored program is rather circumstancial.“ (siehe Mark Priestley: A science of operations, Springer-Verlag, London 2011, Seite 138).

Der Beweis, wonach die Logik einen direkten Einfluss auf den Gedanken des Speicherprogramms hatte, beruht auf Indizien. 


\subsubsection{Ist die Turingmaschine speicherprogrammiert?}

Bei der Diskussion, ob Turing oder von Neumann das Speicherprogramm ausgedacht hat, stellt sich zunächst die Grundfrage, ob die Turingmaschine ein gespeichertes Programm hat. Dazu sind widersprüchliche Meinungen festzustellen: Für die einen ist die Turingmaschine speicherprogrammiert, für die anderen nicht. Ist die Turingmaschine nicht speicherprogrammiert, dürfte sich die endlose Debatte erübrigen.

\section{Turingmaschine ohne beschreibbaren Innenspeicher}

Bei der Turingmaschine wird zwischen einem Programm- und einem Datenspeicher unterschieden. Das Steuerprogramm und die Daten sind folglich nicht im gleichen Speicher abgelegt.

Nach Wolfgang Coy hat die Turingmaschine einen (unendlichen) externen Datenspeicher (Speicherband) und einen (endlichen) unveränderbaren internen Programmspeicher (Zustandsspeicher) (siehe Wolfgang Coy: Speicher-Medium, in: Wolfgang Reisig; Johann-Christoph Freytag (Hg.): Informatik. Aktuelle Themen im historischen Kontext, Springer-Verlag, Berlin, Heidelberg 2006, Seite 81). Demnach hat die Turingmaschine einen internen Festspeicher, sie ist „fest verdrahtet“.

Haigh streitet den vom britischen Turing-Spezialisten Copeland behaupteten Einfluss Turings auf von Neumann ab:

„Edvac went far beyond this to store a program in addressable internal memory rather on a sequential instruction tape. To suggest this advance came from Turing is odd, as the machine Turing described had no internal writable memory and took its instructions from a tape." (siehe Thomas Haigh: Actually, Turing did not invent the computer, in: Communications of the ACM, Band 57, 2014, Heft 1, Seite 41).

Nach von Neumanns Edvac-Bericht soll das Programm statt auf einem (externen) sequentiellen Befehlsstreifen (Lochband) in einem adressierbaren internen Speicher abgelegt werden. Die Aussage, dieser Gedanke stamme von Turing, ist seltsam, denn die von Turing vorgestellte Maschine hatte keinen beschreibbaren internen Speicher. Sie bekam ihre Anweisungen von einem Band.

Eine universelle Turingmaschine ist eine Turingmaschine, die jede beliebige Turingmaschine nachbilden kann. Das Programm der nachgeahmten Maschine, ein Fremdprogramm, befindet sich dabei im Datenspeicher (Speicherband) der universellen Turingmaschine. Die universelle Turingmaschine trägt zwar den Gedanken des Speicherprogramms in sich, ist aber - im Unterschied zum Von-Neumann-Rechner - selbst nicht speicherprogrammiert. Eine (universelle) Turingmaschine kann ihr eigenes Programm während der Laufzeit nicht verändern. Die (universelle) Turingmaschine, ein Gedankenmodell, ist daher kein Von-Neumann-Rechner, sie kann aber einen Von-Neumann-Rechner simulieren. 


\subsubsection{Turingmaschine: Programm und Daten auf demselben Speicher? (Speicherband als Programm -und Datenspeicher)}

Friedrich Bauer glaubt: „Die Turing-Maschine kann ebenfalls als speicherprogrammierter Rechner aufgefasst werden.“ (siehe Friedrich Bauer: Historische Notizen zur Informatik, Springer-Verlag, Berlin, Heidelberg 2009, Seite 140, Fußnote).

Aspray schreibt im Kapitel „Logic machines“ in dem von ihm herausgegebenen Werk:

„The importance of the universal Turing machine to computer science becomes clear once it is recognized that it is a theoretical model of a digital, stored-program computer. Instructions programming the operation of the machine, as well as data, are entered on the tape. The tape serves the dual function of input-output medium and memory - similar to magnetic tape in computers (which is used, however, only as a secondary storage medium).“ (siehe William Aspray (Hg.): Computing before computers, Iowa State university press, Ames, Iowa 1990, Seiten 118-119).

Die Bedeutung der universellen Turingmaschine für die Informatik offenbart sich, sobald man erkennt, dass sie ein theoretisches Modell eines digitalen speicherprogrammierten Rechners ist. Programmanweisungen für den Rechenbetrieb wie auch die Daten werden auf dem Band abgelegt. Dieses hat eine doppelte Aufgabe als Eingabe-Ausgabe-Medium und als Speicher - ähnlich dem Magnetband in Elektronenrechnern (das jedoch nur als externer Massenspeicher verwendet wird).

Ganzhorn und Walter glauben:

„Die Turingmaschine hat einen bandförmigen Speicher, eine primitive Lese- und Schreibeinrichtung und eine Programmiertrommel, deren Inhalt selbst wieder mit einer Turingmaschine identisch gemacht werden kann. Durch Kopieren solcher Trommelinformationen kann eine spezifische Turingmaschine zu einer allgemeinen erweitert werden, deren Universalität die berechenbaren Zahlen erfasst.“ (siehe Karl Ganzhorn; Wolfgang Walter: Die geschichtliche Entwicklung der Datenverarbeitung, IBM Deutschland, Stuttgart 1975, Seite 67).

Copeland hält fest:

„The universal Turing machine consists of a limitless memory in which both data and instructions are stored, in symbolically encoded form, and a scanner that moves back and forth through the memory, symbol by symbol, reading what it finds and writing further symbols. By inserting different programs into the memory, the machine can be made to carry out any calculation that can be done by a human computer. That is why Turing called the machine universal." (siehe Brian Jack Copeland: Colossus. The secrets of Bletchley Park's codebreaking computers, Oxford university press, Oxford 2006, Seite 104).

Die universelle Turingmaschine besteht aus einem unendlichen Speicher, in dem sowohl Daten als auch Befehle in symbolisch verschlüsselter Form gespeichert sind, und einem Schreib-Lese-Kopf, der sich im Speicher hin und her bewegt, Zelle für 
Zelle, und dabei die vorliegenden Zeichen liest und weitere Zeichen schreibt. Bringt man verschiedene Programme in den Speicher ein, so kann man die Maschine dazu veranlassen, jede beliebige Berechnung auszuführen, die menschliche Rechnerinnen und Rechner machen können. Daher hat Turing die Machine als universell bezeichnet.

\title{
1.7.10 Turingmaschine: Programm und Daten auf unterschiedlichen Speicherbändern?
}

\begin{abstract}
„The argument goes on to point out that Turing's universal machine seems to incorporate this idea: the tape of the universal machine contains a representation of the machine simulated, as well as the other data required by the simulation. [...]. One objection that can be made to this is the observation that the use of a single tape is not essential to Turing's arguments. A universal machine requires access to some representation of the machine it is simulating, but this representation does not need to be in the same medium as the data generated in the course of the simulation. Turing's arguments in 1936 would not have been affected if he had equipped the universal machine with a second tape to hold the coded table of the machine being simulated.“ (siehe Mark Priestley: A science of operations, Springer-Verlag, London 2011, Seiten 137-138).
\end{abstract}

In der Auseinandersetzung wird darauf hingewiesen, dass die universelle Turingmaschine anscheinend diesen Gedanken (Haltung von Anweisungen und Daten im gleichen Speicher) in sich birgt: Das Band der universellen Maschine enthält sowohl eine Darstellung der nachgeahmten Maschine als auch die übrigen Daten, welche für die Nachahmung notwendig sind. [...]. Dagegen lässt sich einwenden, dass die Nutzung eines einzigen Bandes für Turings Beweisführung nicht entscheidend ist. Eine universelle Maschine erfordert zwar den Zugang zu einer Darstellung der zu simulierenden Maschine. Diese Darstellung muss aber nicht auf dem gleichen Speichermedium sein wie die im Lauf der Nachbildung erzeugten Daten.

Wenn Turing die universelle Maschine mit einem zweiten Band ausgestattet hätte, welches das Programm der zu simulierenden Maschine aufbewahrt, so hätte das seine Aussagen von 1936 nicht beeinträchtigt.

Hinweis

Es gibt Einband- und Mehrband-Turingmaschinen.

\subsubsection{Rückwirkende Zeitzeugenaussagen}

Späte, rückwirkende Zeitzeugenaussagen sind grundsätzlich heikel. Es besteht nämlich die Gefahr, dass nachträglich Leistungen in Errungenschaften hineingedeutet werden, die nie darin steckten. 
„The attribution of credit for the invention of the stored-program concept has proved to be very controversial. Turing's universal machine has been retrospectively interpreted as embodying the notion, and some writers have therefore argued that credit ought ultimately to be given to Turing.“ (siehe Mark Priestley: A science of operations, Springer-Verlag, London 2011, Seite 129).

Die Auffassungen, wem das Verdienst für die Schaffung des Speicherprogrammbegriffs zukommt, gehen weit auseinander. Man hat der universellen Turingmaschine rückwirkend die Eigenschaft der Speicherprogrammierung zugeschrieben. Gewisse Verfasser machen daher geltend, dass die Ehre letztlich Turing zustehen sollte.

Copeland stellt fest:

„The first historians to insist that the stored-program concept originated in Turing's 1936 paper were (so far as is known) Brian Carpenter and Bob Doran in a classic article [...]: Carpenter, B. E., Doran, R. W. 'The other Turing machine', The computer journal, vol. 20 (1977), pp. 269-279. They said: 'It is reasonable to view the universal Turing machine as being programmed by the description of the machine it simulates; since this description is written on the memory tape of the universal machine, the latter is an abstract stored program computer (p. 270). In the United States, Martin Davis has been advocating powerfully for the same claim since 1987;' [...].“ (siehe Brian Jack Copeland; Giovanni Sommaruga: The stored-program universal computer: Did Zuse anticipate Turing and von Neumann?, in: Giovanni Sommaruga; Thomas Strahm (Hg.): Turing's revolution, Birkhäuser, Cham, Heidelberg usw., 2015, Seite 60).

Die ersten Historiker, die darauf hinwiesen, dass das Speicherprogrammkonzept seinen Ursprung in Turings 1936er Aufsatz hat, waren (soweit bekannt) Brian Carpenter und Bob Doran in einem bekannten Beitrag [...]: B. E. Carpenter; R. W. Doran 'The other Turing machine', in: The computer journal, Band 20 (1977), Seiten 269-279. Sie schrieben: Es macht Sinn, davon auszugehen, dass die universelle Turingmaschine durch die Beschreibung der Maschine programmiert wird, die sie nachahmt. Denn diese Beschreibung befindet sich auf dem Speicherband der universellen Maschine. Letztere ist ein abstrakter speicherprogrammierter Rechner (Seite 270). In den Vereinigten Staaten vertritt Martin Davis seit 1987 mit Nachdruck dieselbe Meinung.

Die Verfasser ergänzen, dass diese Erkenntnis bei Turings Nachkriegskollegen im National physical laboratory geläufig war und dass Mitglieder von Max Newmans Gruppe in Bletchley Park im zweiten Weltkrieg wussten, dass man Turings universelle Maschine von 1936 in einen praktischen digitalen Elektronenrechner umsetzen konnte.

Anscheinend ist erst seit den späten 1970er bzw. den 1980er Jahren (allgemein) bekannt, dass Turing der Schöpfer des Speicherprogrammkonzepts ist. Das deutet darauf hin, dass der britische Mathematiker den Bau der frühen speicherprogrammierten Digitalrechner kaum beeinflusst hat. 


\subsection{Universeller Rechner $\neq$ speicherprogrammierter Rechner}

Die Meinungen zur Beziehung zwischen Universalmaschinen und Rechnern mit Speicherprogramm widersprechen sich. Ein Beispiel: Die Zuse-Rechner Z3 und Z4 werden zwar als (frei programmierbare) Universalrechner bezeichnet, sie waren aber nicht speicherprogrammiert.

„Turing's 1936 paper is about universal computers which is quite different from the stored-program concept. As explained in Daylight's „A Turing tale“: a stored-program computer can (at best) be viewed as a practical realization of the theoretical concept of a „universal machine“ but not as a synonym. To put it differently: universal computation can also be implemented by means of external paper tape without having a program stored inside the computer." (Stellungnahme eines namenlosen Gutachters zum Aufsatz des Verfassers in der Ausgabe vom Februar 2017 der Communications of the ACM).

In Turings Abhandlung von 1936 geht es um universelle Rechner, was nichts mit dem Begriff des Speicherprogramms zu tun hat. Nach Edgar Graham Daylights „A Turing tale“ könne ein speicherprogrammierter Rechner (bestenfalls) als praktische Umsetzung des theoretischen Konzepts einer „universellen Maschine“ betrachtet werden. Mit anderen Worten: Universelle Berechnungen sind auch mit einem externen Lochstreifen - ohne ein intern gespeichertes Programm - durchführbar.

Nach Daylight (= Karel van Oudheusden) gehört Turing nicht zu den Schöpfern des Speicherprogramms.

„Von Neumann referred here [*)] to Turing's 1936 universal machine, which is not the same as the „stored program“ computer of the 1940s. A „stored program“ is only a means to constructing a practical realization of a „universal Turing machine“. Turing and von Neumann were able to make this observation, exactly because they were well versed in both theory and practice." (siehe Edgar Graham Daylight: A Turing tale, in: Communications of the ACM, Band 57, 2014, Heft 10, Seite 38).

*) Copeland then continues: "On the contrary, von Neumann said that Turing's great positive contribution was to show that one, definite mechanism can be universal."

Von Neumann bezog sich hier [^)] auf Turings universelle Maschine von 1936, was nicht dasselbe ist wie der speicherprogrammierte Rechner der 1940er Jahre. Ein Speicherprogramm ist nur ein Mittel, um eine universelle Turingmaschine $\mathrm{zu}$ verwirklichen. Turing und von Neumann war dieser Unterschied bewusst, denn beide waren sowohl mit der Theorie wie auch mit der Praxis gut vertraut.

*) Copeland fährt dann so fort: „Im Gegenteil, von Neumann sagte, dass Turing in seinem großartiger positiver Beitrag zeigte, dass ein bestimmter Mechanismus universell sein kann. “

Der britische Informatikhistoriker Priestley stellt fest: 
„This suggests that a connection between stored-program computers and the universal machine was not widely made in 1946.“ (siehe Mark Priestley: A science of operations, Springer-Verlag, London 2011, Seite 145).

Dies [Bevorzugung des aus der Praxis entstandenen von Neumann-Rechners gegenüber der vergleichsweise wenig bekannten Logikmaschine Turings] weist darauf hin, dass man 1946 zwischen speicherprogrammierten Rechnern und der universellen Maschine im Allgemeinen keinen Zusammenhang sah.

Für Priestley sind nicht nur die Turingmaschine und Edvac universelle Geräte:

[...] ,a computer does not have to incorporate a stored program in order to be universal in this sense. [...] the argument [...] leads to the conclusion that these machines [Zuse's Z3 or the ASCC] can also be described as universal, despite the fact that they read their programs from external storage devices." (siehe Mark Priestley: A science of operations, Springer-Verlag, London 2011, Seite 147).

[...]. ein Rechner muss kein Speicherprogramm aufweisen, um in diesem Sinn universell zu sein. [...] die Aussage [...] führt zum Schluss, dass diese Maschinen [Zuse Z3 oder IBM ASCC/Harvard mark 1] ebenfalls als universell betrachtet werden können, obwohl sie ihre Programme von externen Speichermedien einlesen.

„After 1950, it became common to describe electronic digital computers as being instantiations of Turing's concept of a universal machine, and stored-program computers are to this day described as being based on the „,von Neumann architecture.“ (siehe Mark Priestley: A science of operations, Springer-Verlag, London 2011, Seite 124).

Nach 1950 wurden elektronische Digitalrechner üblicherweise als Verwirklichung der universellen Turingmaschine betrachtet. Speicherprogrammierte Rechner gelten bis heute als Von-Neumann-Maschinen.

\section{Anmerkung}

In einem Tagungsband des Institute of radio engineers erwähnt Claude Shannon in seinem Beitrag zwar die Turingmaschine (siehe Claude Elwood Shannon: Computers and automata, in: Proceedings of the IRE, Band 41, 1953, Heft 10, Seiten 1234-1241), und Maurice Wilkes führt in seinem Aufsatz den Turingtest (siehe Maurice Vincent Wilkes: Can machines think?, in: Proceedings of the IRE, Band 41, 1953, Heft 10, Seiten 1230-1234) an. Das Speicherprogramm kommt aber nicht zur Sprache.

\subsection{Wer kam zuerst auf die Idee des Speicherprogramms?}

Wem fiel das Speicherprogramm ein? In der Fachliteratur werden mehrere Namen genannt: Charles Babbage, Kurt Gödel, Alan Turing, Konrad Zuse, Presper Eckert/ John Mauchly/Herman Goldstine/Arthur Burks, John von Neumann, Richard Clippin- 
ger, Sergei Lebedew, Heinz Rutishauser. Das Turingjahr 2012 hat den Meinungsstreit erneut entfacht, vor allem zwischen amerikanischen und britischen Fachleuten.

Der Ausdruck Speicherprogramm ist vergleichsweise jung (vgl. Kasten).

\section{Wann taucht der Begriff Speicherprogramm erstmals auf?}

Der Begriff „stored program“ (Speicherprogramm) war in den 1930er und 1940er Jahren noch nicht gebräuchlich. Er taucht möglicherweise erstmals in einem Bericht vom 17. Mai 1949 mit der Überschrift „A calculator using electrostatic storage and a stored program“ (Ein Rechner mit elektrostatischem Speicher und einem gespeicherten Programm) von Nathaniel Rochester auf, und zwar im Zusammenhang mit dem elektronischen Rechenlocher IBM 604 (IBM corporate archives, Somers, New York) (siehe Thomas Haigh; Mark Priestley; Crispin Rope: Eniac in action, MIT press, Cambridge, Massachusetts, London 2016, Seiten 239-240).

Charles Babbage befasste sich im Rahmen seiner analytischen Maschine in den 1830er Jahren am Rande mit nichtstarren Abläufen. Seine unfertige Maschine nutzte kein intern abgelegtes Programm. Als Alan Turing 1936 seine Abhandlung über die (gedankliche) universelle Rechenmaschine verfasste, gab es noch keine Computer im heutigen Sinn. Computer waren damals im englischsprachigen Raum Menschen, die mit mechanischen Tischrechenmaschinen Berechnungen durchführten („human computers with desk calculators").

In die engere Wahl für die Entstehung des Speicherprogramms kommen Alan Turing, Konrad Zuse, Presper Eckert, John Mauchly sowie John von Neumann. Burks und Goldstine hatten an den Vorhaben in Philadelphia und Princeton mitgewirkt und waren anschließend von Neumanns Mitarbeiter. Sie stellten keine (ausschließlichen) Prioritätsansprüche. Clippinger und Lebedew traten erst später auf. Kurt Gödel kommt als Vorläufer in Betracht.

In seiner Einleitung zum Kapitel „Stored program electronic computers“ schrieb Brian Randell:

„Whether or not Babbage had in essence conceived of stored programs there is absolutely no evidence to suggest that this aspect of his work had any influence on later pioneers. In fact the idea of a stored program has little attraction when a machine has only a slow mechanical internal memory. Thus it is not surprising that Zuse, whose 1936 paper, reprinted earlier, contains a comparatively clear reference to the possibility of a stored program, does not seem to have pursued the idea any further. Turing's 1936 paper can perhaps be regarded as implying the stored program concept, and there has recently been some speculation [...] as to whether, through his wartime contacts with von Neumann and his association with the secret British code-breaking machines, he might have played some part in the development of the practical stored program concept. Should this in fact turn out to be the case, his paper, which is usually regarded as being of „merely theoretical“ importance, will be seen to have been considerably undervalued. However at present it still seems reasonable to assume that the concept originated with the Eniac group, in 1944 or 1945. (The earliest known document [...] by Turing on electronic computers, his proposal for the ACE computer [...] at the National Physical Laboratory, the pilot version of which was completed in 1951, was written in 1945 but refers to von Neuman's draft report on 
Edvac, which is discussed below).“ (siehe Brian Randell (Hg.): The origins of digital computers, Springer-Verlag, Berlin, Heidelberg usw., 3. Auflage 1982, Seite 376).

Ob Babbage das Speicherprogramm im Kern ausgedacht hat oder nicht: es gibt keinerlei Belege dafür, dass dieser Gesichtspunkt seiner Arbeit irgendeinen Einfluss auf spätere Pioniere hatte. Der Gedanke zu einem gespeicherten Programm ist ja wenig verlockend, wenn eine Maschine bloß einen langsamen mechanischen Innenspeicher hat. Daher überrascht es nicht, dass Zuse offenbar die Idee nicht weiter verfolgt hat. Sein weiter vorn abgedruckter Aufsatz von 1936 enthält nämlich einen vergleichsweise klaren Hinweis auf die Möglichkeit eines Speicherprogramms [Patentanmeldung vom 11. April 1936, auszugsweise auf den Seiten 163-170 auf Englisch wiedergegeben]. Man kann vielleicht davon ausgehen, dass Turings Abhandlung von 1936 den Begriff des gespeicherten Programms einschließt.

Vor kurzem wurde vermutet, dass er - aufgrund seiner Kontakte während des Kriegs mit von Neumann und seiner Beziehung zu den geheimen britischen Entzifferungsmaschinen - möglicherweise an der Entwicklung des praktischen Speicherprogrammkonzepts beteiligt war. Träfe das zu, würde man seine Abhandlung in erheblichem Maß unterschätzen. Ihr wird in der Regel nur eine „theoretische“ Bedeutung zugemessen. Zurzeit nimmt man jedoch immer noch an, dass das Konzept 1944 oder 1945 in der Eniac-Gruppe entstand. (Das früheste bekannte Schriftstück von Turing über Elektronenrechner, sein Vorschlag zum Bau des Ace-Computers für das National physical laboratory, wurde 1945 verfasst. Das Versuchsmodell war 1951 fertig gestellt. Das Dokument verweist auf von Neumanns Edvac-Bericht, der unten besprochen wird).

Randell fährt fort:

„The draft report makes no mention of the consequences, from the point of view of either logical design or of programming, of the decision to store instructions in the internal memory. (Indeed in the report it states that stored instructions and data are to be distinguished, and provisions are made for modifying only the address field of an instruction.)" (siehe Brian Randell (Hg.): The origins of digital computers, Springer-Verlag, Berlin, Heidelberg usw., 3. Auflage 1982, Seiten 377-378).

Der Edvac-Bericht erwähnt die Auswirkungen der internen Befehlsspeicherung auf den logischen Entwurf und die Programmierung nicht. (Die Abhandlung legt freilich fest, dass gespeicherte Anweisungen und Daten zu unterscheiden sind. Es werden Vorkehrungen getroffen, damit nur der Adressteil eines Befehls geändert wird).

Ganzhorn und Walter halten fest:

„Hierin [Edvac-Bericht] forderte er [von Neumann] erstmalig, neben den Zahlenwerten auch das Programm mit Operationsbefehlen und Adressen intern als Information zu speichern.“ (siehe Karl Ganzhorn; Wolfgang Walter: Die geschichtliche Entwicklung der Datenverarbeitung, IBM Deutschland, Stuttgart 1975, Seite 53). 
Der amerikanische Zeitzeuge und Rechnerpionier Harry Huskey berichtet über seine Erfahrungen mit Eniac und Edvac:

„Who was responsible for the concept of the stored-program computer? [...]. Storing instructions like data in the delay lines was the only way that the instructions would be available at the required speed. I think Eckert deserves credit for the stored-program concept.“ (siehe Brian Jack Copeland (Hg.): Alan Turing’s electronic brain, Oxford university press, Oxford 2012, Seite 283).

Von wem stammt der Begriff des speicherprogrammierten Rechners? Nur wenn man die Anweisungen gleich wie die Daten im Quecksilberspeicher aufbewahrt, stehen die Anweisungen rechtzeitig zur Verfügung. Ich glaube, dass wir das Konzept des gespeicherten Programms Eckert verdanken.

Huskey war vom Edvac-Bericht nicht angetan:

„The first draft of a report on the Edvac was of little help to those of us working on the project, because von Neumann approached the topic from the more theoretical point of view. His report was of little value to the computer designer.“ (siehe Brian Jack Copeland (Hg.): Alan Turing's electronic brain, Oxford university press, Oxford 2012, Seite 283).

Der Edvac-Bericht war für die am Vorhaben Beteiligten wenig hilfreich, denn von Neumann behandelte den Gegenstand aus ziemlich theoretischer Sicht. Seine Abhandlung war für den Rechnerbauer wenig nutzbringend.

Der britische Informatikhistoriker Martin Campbell-Kelly stellt fest:

„If one examines the Ace and the Edvac reports side by side, it is plain that much of Turing's notation as well as some aspects of the design of the Ace are derived from the Edvac. [...]. The use of „logical elements“ is derivative, and some of Turing's diagrams are almost identical to von Neumann's. Likewise, the addressable memory of fixed-length binary numbers had no equivalent in the Turing machine." (siehe Brian Jack Copeland (Hg.): Alan Turing's electronic brain, Oxford university press, Oxford 2012, Seite 157).

Nimmt man die beiden Berichte zu Ace und Edvac näher unter die Lupe, so wird klar, dass Turing manche Bezeichnungen wie auch einige Entwurfsideen vom Edvac übernommen hat. [...]. Das gilt auch für die Verwendung von logischen Bausteinen. Mehrere Schaubilder stimmen mit den vonneumannschen Diagrammen weitgehend überein. Der ansprechbare Speicher mit Binärzahlen fester Länge kommt in der Turingmaschine nicht vor.

Anweisungen waren im Edvac nacheinander abgelegt. Im Unterschied dazu konnten sie im Ace-Rechner beliebig angeordnet werden, weil jeder Befehl den nächsten bestimmte.

Philadelphia als Ursprungsort des Speicherprogramms?

Priestley sieht den Ursprung des Speicherprogramms in den USA: 
„The stored-program concept was evolved by the Eniac group in collaboration with the mathematician John von Neumann, who joined them on a consultancy basis in 1944, and was first described in a proposal describing the Eniac's successor, known as the Edvac." (siehe Mark Priestley: A science of operations, London 2011, Seiten 123-124).

Das Speicherprogrammkonzept wurde von der Eniac-Gruppe in Zusammenarbeit mit dem Mathematiker John von Neumann entwickelt. 1944 schloss er sich ihr als Berater an. Die Idee wurde erstmals in einem Bericht erläutert, der den Eniac-Nachfolger Edvac beschrieb.

„This decision to have a single uniform memory is the innovation that makes the draft report the canonical source of the stored-program idea. Again, although von Neumann did not comment on this, the design is reminiscent of Turing's universal machine, which used its single tape to store both the information required for, and that generated in the course of, a computation." (siehe Mark Priestley: A science of operations, Springer-Verlag, London 2011, Seiten 134-135).

Die Entscheidung für einen einzigen einheitlichen Speicher macht den Edvac-Bericht zur maßgebenden Quelle für den Gedanken des Speicherprogramms. Obwohl sich von Neumann dazu nicht äußerte, erinnert dieser Entwurf an die universelle Turingmaschine. Diese verwendet bei einer Berechnung ihr einziges Band für die Speicherung sowohl der Ausgangsdaten wie auch der Ergebnisse.

\section{Hinweis}

Speicherplatz war damals knapp und teuer. Ein einziger Speicher für Anweisungen und Daten erhöhte die Flexibilität.

\section{Haigh, Priestley und Rope erkären:}

„The fourth objective, the simpler and faster setting up of problems, was eventually met by storing program information and data in the same high-speed memory. It is not clear if the team had this method in mind when setting the goal, or whether the idea predated von Neumann's involvement.“ (siehe Thomas Haigh; Mark Priestley; Crispin Rope: Eniac in action, MIT press, Cambridge, Massachusetts, London 2016, Seite 135).

Das vierte Ziel, nämlich die einfachere und schnellere Programmierung von Aufgaben, ließ sich schließlich erreichen, indem man Anweisungen und Daten im gleichen Hochgeschwindigkeitsspeicher ablegte. Es ist offen, ob die Arbeitsgruppe bei der Planung an diese Lösung dachte oder ob man schon vor von Neumanns Beteiligung auf diesen Gedanken kam.

„The „stored program concept“ is almost universally agreed to have been present in von Neumann's „First Draft of a Report on the Edvac“ [...]. Authors have disputed whether the First Draft was the first or the most influential statement of the concept. Some favor either Alan Turing or J. Presper Eckert and John Mauchly as its true originator or originators.“ (siehe Thomas Haigh; Mark Priestley; Crispin Rope: Eniac in action, MIT press, Cambridge, Massachusetts, London 2016, Seite 231) 
Es wird allgemein anerkannt, dass die Idee des Speicherprogramms in von Neumanns „First Draft of a Report on the Edvac“ enthalten ist [...]. Umstritten bleibt, ob dies die erste oder einflussreichste Darstellung dieses Sachverhalts ist. Einige Fachleute betrachten entweder Alan Turing oder Presper Eckert und John Mauchly als Urheber.

Universelle Turingmaschine ist kein Bauplan für speicherprogrammierte Rechner

Der israelische Informatikhistoriker Leo Corry kommt in seinem Aufsatz „Turing's pre-war analog computers: The fatherhood of the modern computer revisited“ (Communications of the ACM, Band 60, 2017, Heft 8, Seite 50) zu drei Kernaussagen:

„There is no straightforward, let alone deterministic, historical path leading from Turing's 1936 ideas on the Universal Machine to the first stored-program electronic computers of the mid1940s.“

„Turing's own pre-war ideas on the Universal Machine were not intended as a possible blueprint for the actual construction of physical automatic calculating machines.“

„Turing's personal interaction with von Neumann while at Princeton had little impact, if at all, on the later involvement of both men on the design and construction of the early stored-program computers, beginning in the mid-1940s.“

Es gibt keinen geraden, geschweige denn vorbestimmten historischen Weg, der von Turings Gedanken von 1936 über die universelle Maschine zu den ersten, Mitte der 1940er Jahre entstandenen speicherprogrammierten Elektronenrechnern führt.

Turings Vorkriegsgedanken über die universelle Maschine waren nicht gedacht als mögliche Vorlage für den tatsächlichen Bau physischer Rechenautomaten.

Turings persönliche Beziehung zu John von Neumann während seines Aufenthalts in Princeton hatte, wenn überhaupt, nur einen geringen Einfluss auf die spätere Beteiligung beider Männer am Entwurf und Bau der frühen speicherprogrammierten Rechner Mitte der 1940er Jahre.

Sowohl Einstein wie auch Gödel (vgl. Abb. 1.2) waren in Princeton tätig. 


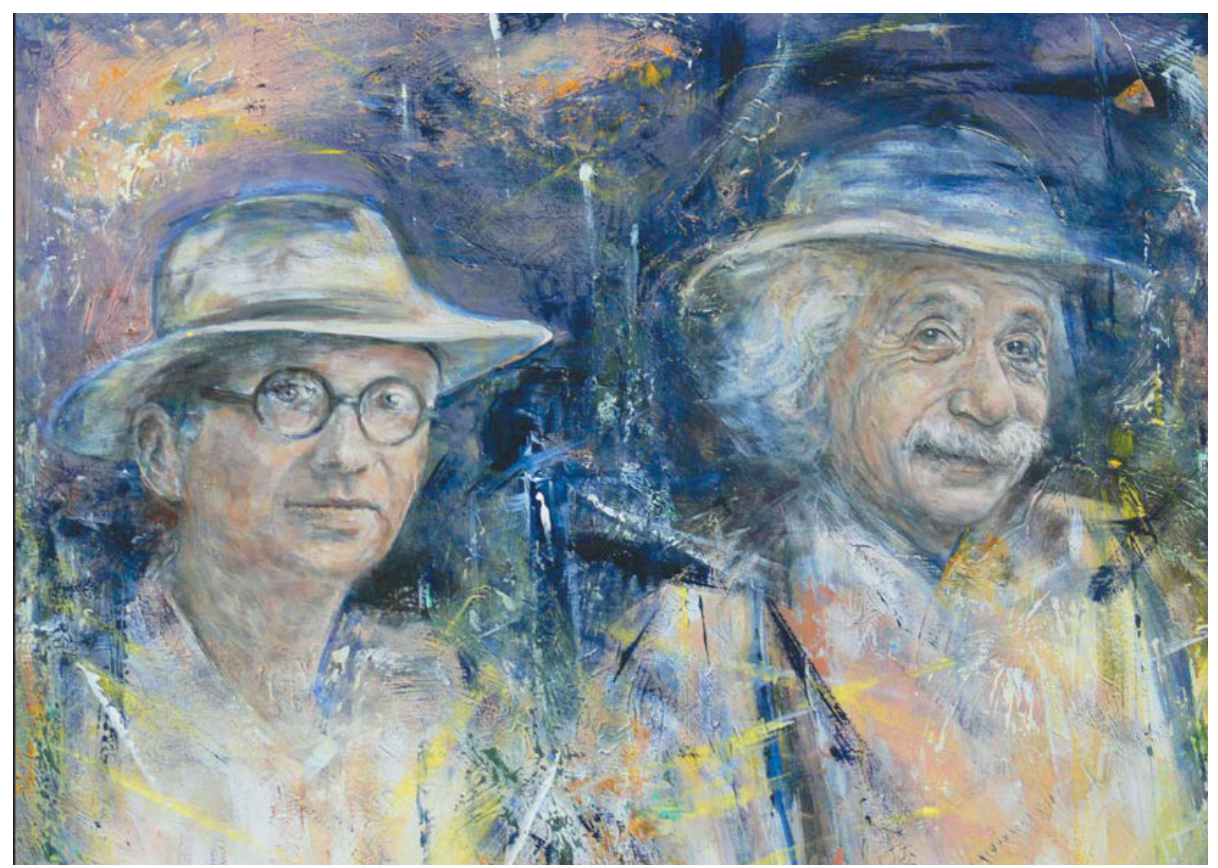

Abb. 1.2: Gödel und Einstein. Princeton war eine Zufluchtsstätte sowohl für Albert Einstein als auch für Kurt Gödel (@ Ingrid Zámečníková, Bratislava).

\subsubsection{Kurt Gödel als Stammvater des Speicherprogramms?}

Vardi, ehemals langjähriger Chefredakteur der Communications of the ACM, geht davon aus, dass das Speicherprogramm - die Gleichbehandlung von Programm und Daten - im Kern auf Kurt Gödel (1931) zurückzuführen ist (siehe Moshe Vardi: Who begat computing?, in: Communications of the ACM, Band 56, 2013, Heft 1, Seite 5).

Die Verschlüsselung von Anweisungen in Form von Zahlen ist ein altes Verfahren. Nach dem amerikanischen Informatikhistoriker Aspray kam Turing zweifellos dank Gödels Unvollständigkeitssatz auf diesen Gedanken.

„Turing's ACE report provided the first complete design of a stored program computer architecture, for Turing allowed instructions to be encoded as numbers and thereby to be stored in the memory just like other data.“ (siehe William Aspray: From mathematical constructivity to computer science: Alan Turing, John von Neumann, and the origins of computer science in mathematical logic, University of Wisconsin-Madison 1980, Seiten 191-192).

Mit seiner Abhandlung zum Ace-Rechner bot Turing den ersten vollständigen Entwurf für speicherprogrammierte Rechner an, denn er ließ es zu, Befehle als Zahlen zu verschlüsseln. Damit konnten sie gleich wie andere Daten im Speicher abgelegt werden. 
„Turing also provided ACE with the capability of program modification. He allowed for the modification of addresses of instructions as the machine executed. He also allowed for the manipulation of instructions as if they were numbers." (siehe William Aspray: From mathematical constructivity to computer science: Alan Turing, John von Neumann, and the origins of computer science in mathematical logic, University of Wisconsin-Madison 1980, Seite 193).

Turing sah für den Ace-Rechner auch die Fähigkeit zur Programmänderung vor. Befehlsadressen lassen sich während der Abarbeitung anpassen. Anweisungen können gleich wie Zahlen verändert werden.

Bei von Neumann konnten nur Adressen geändert werden. Bei Turing waren bedingte Verzweigungen einfacher.

\subsubsection{Zuses Ansätze zum gespeicherten Programm}

Konrad Zuse hatte sich schon früh Gedanken zum Speicherprogramm gemacht, wie aus einer Patentanmeldung vom 11. April 1936 und aus seinen Lebenserinnerungen hervorgeht:

„Auch der Rechenplan lässt sich speichern, wobei die Befehle im Takt der Rechnung den Steuervorrichtungen zugeführt werden. Die Rechenpläne lassen sich entsprechend in fester Form speichern, falls die Maschine oft dieselbe Rechnung ausführen soll.“ (Patentanmeldung vom 11. April 1936: Verfahren zur selbsttätigen Durchführung von Rechnungen mit Hilfe von Rechenmaschinen).

„Das Prinzip der Programmspeicherung war mir ebenfalls bekannt. Allerdings glaubte ich, dass es sich dabei nicht um eine anmeldungsfähige Erfindung handele; denn konstruktiv werden die gleichen Elemente wie für die Zahlenspeicherung verwendet.“ (siehe Konrad Zuse: Der Computer - Mein Lebenswerk, Springer-Verlag, Berlin, Heidelberg, 5., unveränderte Auflage 2010, Seite 97).

„Während des Krieges wäre es freilich ohnehin kaum möglich gewesen, leistungsfähige Geräte mit Speicherprogrammen zu bauen. Wie in der Anlage 4 des wissenschaftlichen Anhangs gezeigt, wäre es auch wenig sinnvoll gewesen, im Rahmen der elektromechanischen Technik Geräte nach solchen Prinzipien zu konstruieren. Doch fand ich neben der praktischen Arbeit an der Z4 noch Zeit, auf dem Papier Geräte mit Programmspeicherung und Adressumrechnung zu entwerfen. Ich arbeitete die Patentzeichnungen für ein solches Gerät aus, für das außerdem assoziative Speicher vorgesehen waren.“ (siehe Konrad Zuse: Der Computer - Mein Lebenswerk, Springer-Verlag, Berlin, Heidelberg, 5., unveränderte Auflage 2010, Seite 78).

Bei den frühen Zusemaschinen waren Daten- und Programmspeicher (Befehlsspeicher) getrennt. Die Hauptspeicher der ersten Rechenautomaten von Zuse, Aiken und Eckert/Mauchly waren allgemein sehr klein.

Es folgen einige Stellungnahmen zu Zuses Vorstellungen zur Programmspeicherung. Sie wurden in zwei deutschen Dissertationen veröffentlicht. 
„Er [Zuse] hatte bereits 1936 die Möglichkeit vorgesehen, das Programm im Speicher genau so wie die Zahlen zu speichern, da es ja ebenfalls in Ja-Nein-Werte zu zerlegen war. Die sechzehn Worte, die der mechanische Speicher der Z 4 bei Kriegsende enthielt, machte die Speicherung eines größeren Programms unmöglich. Zuse arbeitete den Plan der Programmspeicherung und Adressenrechnung ebenso wie die Möglichkeit des „assoziativen“ Speichers auf dem Papier für eine geplante Patentanmeldung aus.“ (siehe Hartmut Petzold: Rechnende Maschinen, VDI-Verlag, Düsseldorf 1985, Seite 332).

„Im gleichen Jahr [1945] arbeitete Zuse auf dem Papier verschiedene weit über seine gebauten Maschinen hinausreichende Entwürfe und Pläne für Rechner mit Programmspeicherung und Adressenumrechnung aus. Der Entwurf für eine entsprechende Patentschrift enthielt auch den Plan für einen assoziativen Speicher.“ (siehe Hartmut Petzold: Rechnende Maschinen, VDI-Verlag, Düsseldorf 1985, Seite 325).

„Zuse hatte während der letzten Kriegsmonate mit dem Entwurf des Plankalküls eine theoretische Systematik entwickelt, mit der eine erst auf dem Papier konzipierte, sehr leistungsfähige, mit Sprungbefehlen, gespeicherten Programmen und assoziativen Speichern versehene Maschine programmiert werden konnte.“ (siehe Hartmut Petzold: Rechnende Maschinen, VDIVerlag, Düsseldorf 1985, Seite 480).

„Weitgehend unbekannt und international kaum akzeptiert ist, daß Zuse auch die Möglichkeit der Programmspeicherung sowie die Möglichkeit des Einsatzes bedingter Befehle frühzeitig erkannte.“ (siehe Rolf Zellmer: Die Entstehung der deutschen Computerindustrie, Dissertation, Universität Köln 1990, Seite 57).

Die ersten englischsprachigen Veröffentlichungen zur Zusemaschine tauchen nach bisherigem Wissen erst 1947 auf. Im Ausland wurde der deutsche Wegbereiter in den ersten Nachkriegsjahren kaum zur Kenntnis genommen.

\subsubsection{Mechanik bremst Elektronik}

Beim amerikanischen Röhrenrechner Eniac wurden die Daten mit elektronischer Geschwindigkeit übertragen und verarbeitet. Die Programme musste man aber mechanisch über Steckverbindungen und Drehschalter eingeben, was den Rechenbetrieb lähmte. Die Steuerung des Relaisrechners Harvard mark1/IBM ASCC erfolgte über Lochstreifen. In diesem Fall war der Geschwindigkeitsunterschied weniger ausgeprägt, weil ausschließlich mechanische Geräte eingesetzt wurden.

Nur wenn die Anweisungen in einem sehr schnellen Speicher zur Verfügung stehen, lässt sich die hohe Geschwindigkeit von Elektronenrechnern ausschöpfen. Diese Einsicht war nahe liegend und schlug sich im Von-Neumann-Bericht nieder. Für die Umsetzung bedurfte es jedoch leistungsfähiger Trägermedien. Der Mangel an Speicherplatz blieb lange Zeit ein Dauerproblem. Wenn Daten und Programme im gleichen Speicher gehalten wurden, ließ sich der knappe, kostspielige Platz besser ausnutzen (einfachere Aufteilung). Sind die Anweisungen in einem (elektronischen) 
Schnellzugriffsspeicher aufgehoben, lassen sie sich wie Daten ändern, und zwar während der Abarbeitung des Programms.

\subsubsection{Durchbruch des Speicherprogramms dank von Neumann}

Es ist offensichtlich, dass der einflussreiche John von Neumann vom Institute for advanced study (Princeton) mit seinen Abhandlungen aus den Jahren 1945 und 1946 der Einführung des Speicherprogramms zum Durchbruch verholfen hat. Ort der Handlung war die Moore school of electrical engineering der Universität von Pennsylvania in Philadelphia, wo das Ungetüm Eniac fertig gestellt wurde. Die Programmierung dieser von John Mauchly und Presper Eckert gebauten Riesenanlage über Steckkabel und Schalter war mühsam. Ein wirksameres Vorgehen drängte sich auf.

Heinz Rutishauser, der Erfinder der automatischen Programmierung und maßgeblicher Vater der Programmiersprache Algol, stellte am 29. November 1952 in seiner Antrittsvorlesung an der ETH Zürich fest, dass die Programmspeicherung um 1947 eingeführt wurde:

\footnotetext{
„Durch die Einführung der Entscheidungsbefehle und der Unterprogramme wurde der Wirkungsbereich der programmgesteuerten Rechenmaschinen wesentlich erweitert. Dagegen befriedigten die Lochstreifen als Programmträger bald nicht mehr, da bei schnellen Maschinen das Abtasten der Befehle der Rechengeschwindigkeit nicht mehr folgen konnte. Zum Teil aus diesem, zum Teil aus anderen Gründen ist man ungefähr im Jahre 1947 noch einen Schritt weitergegangen. Da die während der Rechnung gebrauchten Zahlen in der Maschine gespeichert werden, kann man ebenso gut auch das ganze Rechenprogramm mit all seinen Unterplänen in der Maschine speichern und durch Zahlen darstellen. Da also die einzelnen Befehle in der Maschine wie Zahlen behandelt werden, haben wir sogar die Möglichkeit, das Programm während der Rechnung noch abzuändern, wovon man in der Tat gerne Gebrauch macht.“ (siehe Hanna Rutishauser; Walter Gander: Programmieren, welche Bürde!, in: Informatik-Spektrum, Band 38, 2015, Seite 153).
}

\subsubsection{Turing, von Neumann oder Eckert/Mauchly?}

Hat der damals wenig bekannte Alan Turing von der Universität Cambridge in seiner bahnbrechenden Arbeit zur universellen Rechenmaschine von 1936 den Grundstein für das zukunftsträchtige Vielzweckgerät gelegt?

Nehmen wir an, dass Turing der Begründer der Programmspeicherung war. Weshalb wurden dann seine Erkenntnisse für die im zweiten Weltkrieg gebauten britischen und amerikanischen Relais- und Röhrengeräte nicht übernommen? Wie groß war sein Einfluss auf von Neumann und die englischen Konstrukteure Thomas Flowers, Frederic Williams, Thomas Kilburn, Maurice Wilkes und Andrew Booth?

Der Anstoß für die Verwirklichung des Speicherprogramms bei den englischen Nachkriegsrechnern (Universitäten Manchester, Cambridge, London) ging offenbar 
nicht von Turing aus, sondern kam aus Philadelphia (Vorlesungsreihe 1946) und Princeton (Gastaufenthalte europäischer Forscher). Hat Turing die Bekanntgabe seiner Errungenschaften vernachlässigt, oder wurde ihre Bedeutung nicht erkannt? Weshalb hat von Neumann Turings Verdienste in seinen Schriften nicht (angemessen) gewürdigt?

\section{Von Neumann oder Eckert/Mauchly?}

1945 begann ein erbitterter Zwist zwischen Presper Eckert und John Mauchly (Universität von Pennsylvania in Philadelphia) einerseits und John von Neumann (Institute for advanced study, Princeton) andererseits. Die betroffenen Wegbereiter (Presper Eckert, John Mauchly) und manche Zeitgenossen haben Stellung zum Werden des Speicherprogramms genommen, manchmal allerdings erst deutlich später: Alice Burks, Arthur Burks, Herman Goldstine aus dem „Lager“ von Neumanns, ferner amerikanische und britische Fachleute: Harry Huskey, Nicholas Metropolis und Maurice Wilkes. Aus den deutschsprachigen Ländern meldeten sich Friedrich Bauer, Wilfried de Beauclair, Fritz-Rudolf Güntsch, Ambros Speiser, Heinz Zemanek und Konrad Zuse zu Wort. Im Mittelpunkt der Erörterungen stand jeweils die Frage: Wem steht das Erstrecht zu, von Neumann oder Eckert/Mauchly? Turing wurde dabei üblicherweise nicht genannt. John von Neumann hat zu den Anfeindungen, soweit bekannt, stets geschwiegen.

Auch namhafte Technikhistorikerinnen und -historiker haben sich mit dem Streit befasst, z.B.: William Aspray, Paul Ceruzzi, Nancy Stern, Michael Williams. Die Meinungen sind gegensätzlich. Die einen gehen davon aus, dass sich von Neumann mit fremden Federn geschmückt hat. Die anderen halten ihn für den geistigen Vater der gespeicherten Programms.

\section{Von Neumann oder Turing?}

Seit einiger Zeit geht es bei der Auseinandersetzung zwischen englischsprachigen Technikhistorikern nun vorwiegend um das Erstrecht von Alan Turing und John von Neumann. Konrad Zuse wird dabei selten erwähnt. In seinem Vorschlag zum Bau eines speicherprogrammierten Rechners (Ace) von 1945 zitiert Turing von Neumann, von Neumann führt Turing in seinem Bericht zum Rechnerbau (Edvac) hingegen nicht an. Britische Geschichtsschreiber setzen sich z.T. für Turing ein, amerikanische wehren sich bevorzugt für von Neumann.

In diesem Zusammenhang gibt Vardi zu bedenken:

[...] ,we should not confuse a mathematical idea with an engineering design. It was the Edvac report of 1945 that offered the first explicit exposition of the stored-program computer." (siehe Moshe Vardi: Who begat computing?, in: Communications of the ACM, Band 56, 2013, Heft 1, Seite 5).

Wir sollten einen mathematischen Gedanken nicht mit einem technischen Vorhaben verwechseln. Der Edvac-Bericht hat 1945 erstmals den speicherprogrammierten Rechner ausdrücklich beschrieben. 


\section{Eine Frage der Definition?}

Teresa Numerico unterscheidet drei Bedeutungen des Begriffs „Speicherprogramm“ (siehe Brian Jack Copeland (Hg.): Alan Turing's electronic brain, Oxford university press, Oxford 2012, Seite 183):

- Anweisungen lassen sich im Speicher als Zahlen verschlüsseln. Diese Vorgehensweise beruht unmittelbar auf der in Gödels Logik verwendeten Arithmetisierungstechnik. Das Speicherprogramm war in diesem Sinn in der universellen Turingmaschine von 1936 vorhanden.

- Anweisungen und Daten werden gemeinsam gespeichert, wobei die gleichen Symbolarten verwendet werden. Dieser Gedanke stammt von der universellen Turingmaschine.

- Anweisungen, die als Zahlen dargestellt sind, können verändert werden. Das führt zu veränderlichen Programmen.

Numerico fügt hinzu, dass laut Edvac-Bericht nur der Adressteil einer Anweisung geändert werden konnte. Von Neumann habe erst später die Idee übernommen, Anweisungen gleich wie Daten zu verändern.

\subsubsection{Schlussfolgerungen}

Die Streitfrage zur Herkunft des Speicherprogramms dürfte sich mangels ausreichender Belege nicht mehr mit Sicherheit klären lassen. Viele Zeitgenossen und die frühen Informatikpioniere haben sich dazu gegensätzlich geäußert. Das Verdienst wurde meist von Neumann oder Eckert zugeschrieben, Turing hingegen kaum berücksichtigt. Alan Turing und John von Neumann haben anscheinend keine Stellung zu dieser Zwietracht genommen. Der Durchbruch der Speicherprogrammierung ist zweifellos der internationalen Ausstrahlung von Neumanns zu verdanken.

Nicht auszuschließen ist, dass mehrere Personen unabhängig voneinander auf den Gedanken des Speicherprogramms kamen, wie das bei vielen Erfindungen geschah. Ob und wie weit sich Turing, von Neumann und Eckert/Mauchly gegenseitig beeinflusst haben, lässt sich nur schwer feststellen.

Das Speicherprogramm hat mehrere Väter (vgl. Kasten).

\section{Mehrere Schöpfer des Speicherprogramms}

Eine mögliche Antwort auf die langjährige Streitfrage:

- Alan Turing ist 1936 in Cambridge aufgrund theoretischer Überlegungen auf den Gedanken des Speicherprogramms gekommen. Seine Erkenntnisse wurden aber weder in Großbritannien noch in Nordamerika verstanden bzw. zur Kenntnis genommen. Er hatte wohl die umfassendste Vorstellung einer Universalmaschine.

- Der Konstrukteur Konrad Zuse dachte ebenfalls 1936 in Berlin an die Möglichkeit der Programmspeicherung, konnte sie jedoch damals nicht in die Praxis umsetzen. Es gab noch keine leistungsfähigen Hauptspeicher. Seine Einsichten blieben weitgehend unbekannt. 
- John von Neumann entwickelte 1945 in Princeton in Zusammenarbeit mit Presper Eckert und John Mauchly (Philadelphia) aufgrund praktischer Erfahrungen mit dem Elektronenrechner Eniac die Idee des gespeicherten Programms.

Turing, Zuse und von Neumann gelangten unabhängig voneinander und aus unterschiedlichen Gründen zu ähnlichen Ergebnissen.

\section{Maßgebliche Darstellungen zur Programmspeicherung}

Hier einige Hinweise auf ausgewählte Schriften zum Thema Speicherprogramm:

- Alan Turing: On computable numbers, with an application to the Entscheidungsproblem (1936, universelle Turingmaschine) sowie The automatic computing engine (1945, Beschreibung eines speicherprogrammierten elektronischen Digitalrechners),

- John von Neumann: First draft of a report on the Edvac (1945, Vorstellung eines speicherprogrammierten elektronischen Digitalrechners),

- Nancy Stern: From Eniac to Univac (1981, Stellungnahme zugunsten von Eckert und Mauchly),

- Alice Burks: Who invented the computer? (2003, Stellungnahme zugunsten von Neumanns).

Für weitere Angaben zu diesem Zwist vgl.

Herbert Bruderer: Konrad Zuse und die Schweiz, de Gruyter Oldenbourg-Verlag, München 2012, Seiten 43-59.

\subsection{Wer hat als Erster die automatische Programmierung ausgedacht?}

Heinz Rutishauser (ETH Zürich) gilt als Erfinder der automatischen Programmierung. Das ist die Grundlage für den Compiler (Programm zur Übersetzung von einer höheren Programmiersprache in die Maschinensprache), siehe Heinz Rutishauser: Automatische Rechenplanfertigung bei programmgesteuerten Rechenmaschinen, Birkhäuser Verlag, Basel 1952 (Habilitationsschrift). Damals sprach man von ,,automatischer Programmierung“, ,automatischer Rechenplanfertigung“ und ,automatischer Formelübersetzung“. Der Ausdruck „automatische Programmierung“ ist missverständlich. Denn nicht die Maschine, sondern der Mensch schrieb die Anweisungen.

Rutishauser ist zudem einer der Väter der Programmiersprache Algol. Beteiligt war u.a. auch Friedrich Bauer (Deutschland). Algol bildete die Grundlage für eine Reihe von „Nachkommen“ (Formelsprachen), z.B. Pascal.

Mit seiner Programmiersprache Plankalkül war Zuse seiner Zeit weit voraus. Weil sie kaum zur Kenntnis genommen wurde, blieb ihr Einfluss freilich gering. Mit Formelübersetzern (Compiler) haben sich auch Grace Hopper (USA, 1952) und Corrado 
Böhm (Italien, 1954) befasst, desgleichen Halcombe Laning und Niel Zierler (USA, 1954).

Eine Vorstufe der Compiler waren die Planfertigungsgeräte für die Z4 von Konrad Zuse (1945, auch Programmator genannt, unvollendet) und Harvard mark 3 von Howard Aiken (1950). Die Verschlüsselung des Befehlsstreifens wurde durch eine Chiffriermaschine besorgt (siehe Heinz Rutishauser; Ambros Speiser; Eduard Stiefel: Programmgesteuerte digitale Rechengeräte (elektronische Rechenmaschinen), Birkhäuser Verlag, Basel 1951, Seiten 10 und 63).

Die Ausdrücke „Rechenplan“ und „Rechenprogramm“ werden hier der Einfachheit halber einander gleichgesetzt, ebenso „Unterrechenplan“, „Unterplan“ und „Unterprogramm“. Nach der folgenden Umschreibung liegt ein Rechenprogramm in einer höheren Programmiersprache, der Rechenplan hingegen in der Maschinensprache vor:

„Zur Abgrenzung der Begriffe „Rechenprogramm“ und „Befehlsreihe“ (letztere auch Rechenplan genannt [...]), sei nochmals hervorgehoben, dass das Rechenprogramm die durch Formeln und Vorschriften ausgedrückte, noch sehr allgemein gehaltene numerische Lösung der gestellten Aufgabe ist, die an sich für jeden Automaten paßt; demgegenüber bezieht sich die Befehlsreihe immer auf eine spezielle Rechenmaschine.“ (siehe Heinz Rutishauser; Ambros Speiser; Eduard Stiefel: Programmgesteuerte digitale Rechengeräte (elektronische Rechenmaschinen), Birkhäuser Verlag, Basel 1951, Seiten 43-44).

Die gleichen Verfasser haben (1951) das Ungleichgewicht zwischen der hohen Rechengeschwindigkeit einerseits und der mangelhaften Betriebssicherheit sowie der zeitraubenden Vorbereitung des Problems bis zur Herstellung des Lochstreifens andererseits beklagt.

„Es kann nicht bestritten werden, daß die programmgesteuerten Rechenmaschinen infolge Versagens ihrer Bauelemente (Relais, Elektronenröhren, Widerstände, Kondensatoren, mechanische Teile usw.) gelegentlich Rechenfehler begehen.“ (siehe Heinz Rutishauser; Ambros Speiser; Eduard Stiefel: Programmgesteuerte digitale Rechengeräte (elektronische Rechenmaschinen), Birkhäuser Verlag, Basel 1951, Seite 63).

„Der Einsatz einer programmgesteuerten Rechenmaschine lohnt sich um so eher, je häufiger jeder Befehl des Rechenplans im Mittel ausgeführt wird, weil dann die relativ hohen Kosten der Vorbereitung weniger ins Gewacht fallen. Tatsächlich ist der Aufwand für die Aufstellung eines Rechenplans wesentlich größer als die einmalige Durchrechnung aller Befehle desselben auf einer Bürorechenmaschine.“ (siehe Heinz Rutishauser; Ambros Speiser; Eduard Stiefel: Programmgesteuerte digitale Rechengeräte (elektronische Rechenmaschinen), Birkhäuser Verlag, Basel 1951, Seite 45). 


\subsection{Wer hat den ersten Übersetzer (Compiler) geschaffen?}

Als erste Programmiersprache wird üblicherweise Konrad Zuses Plankalkül bezeichnet. Untersuchungen zur Entstehung des Übersetzungsprogramms, des Compilers, sind eher selten. Die Anschauungen zu seiner Herkunft gehen weichen voneinander ab. In manchen Schriften wird die Ehre Grace Hopper (USA) zuteil, was aber umstritten ist. Die Antwort auf die Frage der Priorität (Erstrecht, Vorrang) hängt auch in diesem Fall von der Begriffsbestimmung ab.

In der Frühzeit der Informatik sprach man wie erwähnt von automatischer Programmierung und automatischer Rechenplanfertigung. Der Ausdruck „Compiler“ im heutigen Sinn bürgerte sich erst später ein. Zu lesen war von einem Übersetzer, einem „programmierenden Programm“, einem Programm für die Übersetzung von einer Programmiersprache in die Maschinensprache. Die Bedeutung des Übersetzerbegriffs hat sich mit der Zeit gewandelt. Auf einem Symposium zur automatischen Programmierung von Digitalrechnern (Mai 1954) wurde der Ausdruck je nach Vortrag in unterschiedlicher Weise gebraucht.

Manche sogenannte „Compiler“ waren wenig anspruchsvoll. Das trifft nach Donald Knuth auch für Hoppers Ausgestaltung zu. Der amerikanische Technikhistoriker Ceruzzi meint dazu:

\footnotetext{
„The term „compiler“ has come into common use today to mean a program that translates instructions written in a language that human beings are comfortable with, into binary codes that a computer can execute. That meaning is not what Hopper had in mind. For her, a compiler handled subroutines stored in libraries. A compiler method, according to Hopper's definition, was a program that copied the subroutine code into the proper place in the main program where a programmer wanted to use it." (siehe Paul E. Ceruzzi: A history of modern computing, MIT press, Cambridge, Massachusetts, London, 2. Auflage 2003, Seite 85).
}

Unter dem Begriff „Compiler“ versteht man heute in der Regel ein Programm, das Anweisungen, die in einer für den Menschen verständlichen Sprache geschrieben sind, in binäre Zeichenfolgen überträgt. Diese kann ein Digitalrechner ausführen. Hopper verfolgte jedoch einen anderen Zweck. Nach ihrer Umschreibung handhabte ein Compiler in Bibliotheken gespeicherte Unterprogramme. Er kopierte ein Unterprogramm an den Standort im Hauptprogramm, wo ein Programmierer es verwenden wollte.

Solche Unterprogramme berechneten beispielsweise Winkelfunktionen, Logarithmen und die Gleitkommadarstellung.

\section{Corrado Böhm (Italien)}

Die Erfahrungen mit der Zusemaschine Z4 an der ETH Zürich veranlassten den Italiener Corrado Böhm, einen Übersetzer zu entwerfen (Dissertation 1954). 


\section{Alick Glennie (England)}

Die Engländer J. M. Bennett und Alick E. Glennie erwähnen in ihrem Beitrag „Programming for high-speed digital calculating machines“ (1953) einen Autocode. Nach Christopher S. Strachey wurde dieser Compiler ab September 1952 für den Rechner Manchester mark 1 verwendet.

Hopper veröffentlichte ihren Aufsatz vor Glennie, dennoch betrachtet Knuth Glennie als Schöpfer des ersten echten Compilers, der tatsächlich eingebaut und genutzt worden sei (siehe Donald E. Knuth; Luis Trabb Pardo: The early development of programming languages, in: Nicholas Constantine Metropolis; Jack Howlett; GianCarlo Rota (Hg.): A history of computing in the twentieth century, Academic press, New York, London usw. 1980, Seiten 218 ff.).

\section{Grace Hopper (USA)}

Ein erster „Compiler“ namens A-0 von Grace Murray Hopper war im Frühling 1952 für den Univac-Rechner in Betrieb. Er war Thema ihres Vortrags „The education of a computer“ auf der ersten ACM National conference (Pittsburgh 1952). Verbesserte Fassungen waren A-1 (Januar 1953) und A-2 (August 1953), A-2 wurde Ende 1953 ausgeliefert.

\section{Halcombe Laning und Niel Zierler (USA)}

J. Halcombe Laning und Niel Zierler vom Massachusetts Institute of Technology (MIT) verfassten den Bericht „A program for translation of mathematical equations for Whirlwind 1“ (Januar 1954). Laning schrieb im Sommer 1952 einen vorläufigen algebraischen Übersetzer (Formelübersetzer). Bis Mai 1953 hatte er ihn gemeinsam mit Zierler zu einem brauchbaren Verfahren erweitert.

\section{Alexej Ljapunow (Sowjetunion)}

Der erste Programmierkurs „Grundlagen der Programmierung“ an einer sowjetischen Hochschule fand im Studienjahr 1952/1953 an der Staatsuniversität Moskau statt. Alexej A. Ljapunow ging dabei erstmals auf das Problem der automatischen Programmierung ein. S. S. Kamynin und E. Z. Lubimski vom mathematischen Institut der sowjetischen Akademie der Wissenschaften entwickelten ab 1954 auf dem Rechner Strela ein vorläufiges „Programmierprogramm“. 1955 war die endgültige Fassung des Compilers fertig. Andrej Erschow, L. N. Korolew und V. M. Kurotschkin arbeiteten an einem ähnlichen Vorhaben für den Rechner Besm (siehe Andrei P. Ershov, Michael R. Shura-Bura: The early development of programming in the USSR, in: Nicholas Constantine Metropolis; Jack Howlett; Gian-Carlo Rota (Hg.): A history of computing in the twentieth century, Academic press, New York, London usw. 1980, Seiten 155 ff.).

\section{Schlussfolgerungen}

Diese Darlegungen lassen sich wie folgt zusammenfassen: Heinz Rutishauser schlug als Erster die automatische Programmherstellung vor (maschinelle Übersetzung mithilfe des Rechengeräts, 1951/52). Grace Hopper schuf die ersten Dienstprogramme für 
die Verwaltung von Unterprogrammen (1952). Alick Glennie ist Urheber des ersten echten Compilers, der tatsächlich auf einer Rechenmaschine eingesetzt wurde (1952). Mehr zu Rutishauser im Abschnitt 4.9.

\subsection{Frühzeit der Programmierung}

„In 1914, Leonardo Torres y Quevedo used natural language to describe the steps of a short program for his hypothetical automaton. Helmut Schreyer gave an analogous description in 1939 for the machine that he had helped Konrad Zuse to build." (siehe Donald E. Knuth; Luis Trabb Pardo: The early development of programming languages, in: Donald E. Knuth (Hg.): Selected papers on computer languages, Center for the study of language and information, Stanford 2003, Seite 6, und in: Nicholas Constantine Metropolis; Jack Howlett; Gian-Carlo Rota (Hg.): A history of computing in the twentieth century, Academic press, New York, London usw. 1980, Seite 201).

Leonardo Torres Quevedo verwendete 1914 die natürliche Sprache, um die Schritte eines kurzen Programms für seinen hypothetischen (auf einer unbewiesenen Vermutung beruhenden) Automaten zu beschreiben. Helmut Schreyer erarbeitete 1939 eine ähnliche Darstellung für die Zusemaschine, an deren Bau er mitgewirkt hatte. Die modernen Programmiersprachen hatten manche Vorläufer (vgl. Tab. 1.3).

Tab. 1.3: Frühe Entwicklungen zur Programmierung

\begin{tabular}{llll}
\hline $\begin{array}{l}\text { Bemühungen in den USA und in Europa } \\
\text { Sprache }\end{array}$ & Schöpfer & Jahr & Land \\
\hline $\begin{array}{lll}\text { Plankalkül } \\
\text { flow diagrams }\end{array}$ & Konrad Zuse & 1945 & Deutschland \\
& Herman H. Goldstine, & 1946 & USA \\
composition & John von Neumann & & \\
short code & Haskell B. Curry & 1948 & USA \\
& John W. Mauchly, & 1949 & USA \\
intermediate program language & William F. Schmitt & & \\
Klammerausdrücke & Arthur W. Burks & 1950 & USA \\
formules & Heinz Rutishauser & 1951 & Schweiz \\
autocode & Corrado Böhm & 1951 & Italien \\
A-2 & Alick E. Glennie & 1952 & England \\
algebraic interpreter & Grace Murray Hopper & 1953 & USA \\
(Whirlwind translator) & J. Halcombe Laning, & 1953 & USA \\
autocode & Niel Zierler & & \\
PP-2 & Ralph Anthony Brooker & 1954 & England \\
& S. S. Kamynin & 1954 & Russland \\
\hline
\end{tabular}

(C) Bruderer Informatik, CH-9401 Rorschach 2020 
Quelle

Donald E. Knuth; Luis Trabb Pardo: The early development of programming languages, in: Donald E. Knuth ( $\mathrm{Hg}$.): Selected papers on computer languages, Center for the study of language and information, Stanford 2003, Seite 76.

Die Entwicklung mündete schließlich in die Programmiersprachen Fortran (John Backus, 1954 ff.), Algol und die unzähligen Nachfolger.

Für weitere Angaben zur Geschichte der Programmiersprachen vgl.

Jean E. Sammet: Programming languages: History and fundamentals, Prentice-Hall, Inc., Englewood Cliffs, New Jersey 1969,

Richard L. Wexelblat (Hg.): History of programming languages, Academic press, New York, London usw. 1981.

\subsection{Offene Fragen zur Informatikgeschichte}

Zur Frühgeschichte der Rechentechnik gibt es viele ungeklärte Fragen. Oft fehlen ausreichende Belege. Ungewiss sind beispielsweise die Beziehungen zu Vorläufern: Welche Wegbereiter haben John Napier, Jost Bürgi, Wilhelm Schickard, Blaise Pascal, Gottfried Wilhelm Leibniz, Jacques Vaucanson, Pierre Jaquet-Droz, Charles Babbage, Herman Hollerith, Leonardo Torres Quevedo, Alan Turing und Konrad Zuse gekannt?

Es folgen einige ausgewählte Fragen:

- Hat John Mauchly beim Bau des Röhrenrechners Eniac das Urheberrecht von John Atanasoff verletzt?

Im langwierigen Patentprozess wurde Atanasoff als Erfinder des digitalen elektronischen Rechenautomaten (ABC) bestimmt. Das Bundesgerichtsurteil (1973) ist jedoch nach wie vor umstritten.

- Wurde John von Neumann von Alan Turings Abhandlung über die universelle Turingmaschine (1936) beeinflusst?

Warum fehlen in von Neumanns Bericht (1945) nähere Quellenangaben? Hat von Neumann das Urheberrecht von Alan Turing, Presper Eckert und John Mauchly verletzt?

- Wem ist die Idee des Speicherprogramms zu verdanken?

Am häufigsten werden Alan Turing und John von Neumann erwähnt. Zu nennen sind auch Konrad Zuse, Presper Eckert und John Mauchly. Unklar ist, ob von Neumann die Gedanken zum Speicherprogramm von Turing oder anderen Fachleuten übernommen oder unabhängig hatte.

- Auf wen geht die Trennung von Steuerwerk (Leitwerk), Rechenwerk, Speicherwerk sowie Eingabe- und Ausgabeeinheit zurück?

Damit haben sich vor John von Neumann schon Charles Babbage und Konrad Zuse befasst. 
- Hat Grace Hopper den Compiler (Übersetzer) erfunden?

Dieses Verdienst wird meist Hopper (1952) zugeschrieben, es kommt aber eher Alick Glennie (1952) zu. Im Spiel ist auch der Name von Heinz Rutishauser, der wohl als Erster die automatische Programmierung (1951/52) vorschlug.

- Wer ist der Vater des Computers?

Diese Ehre wird verschiedenen Bahnbrechern zuteil: Howard Aiken, John Atanasoff, Charles Babbage, Presper Eckert, Thomas Flowers, John Mauchly, George Stibitz, Leonardo Torres Quevedo, Alan Turing, John von Neumann, Konrad Zuse. Es gibt offensichtlich mehrere Erfinder.

- Wer hat das erste Rechenprogramm geschrieben?

Als erste Programmiererin gilt Ada Lovelace mit ihrem Aufsatz (1843) über die analytische Maschine von Charles Babbage. Der erste Programmierer war aber wohl Babbage.

- Von wem stammt die erste Programmiersprache?

Allgemein wird der Plankalkül (1945/46) von Konrad Zuse als erste Programmiersprache oder als erster Vorläufer betrachtet.

- Wer hat das erste Schachprogramm geschrieben?

Gedanken zu Schachprogrammen haben sich schon Alan Turing (1941) und Konrad Zuse (Plankalkül 1945/46, logistisches Gerät) gemacht. Dabei wird aber die Schachmaschine von Leonardo Torres Quevedo (1912) übersehen.

- Wer hat die maschinelle (künstliche) Intelligenz begründet?

Babbage, Torres Quevedo, Turing, Zuse?

- Hat der britische Premierminister Winston Churchill nach dem zweiten Weltkrieg die Beseitigung der geheimen Colossus-Rechner angeordnet?

- Wer ist Urheber der Mikroprogrammierung? Charles Babbage, Alan Turing, Maurice Wilkes? Diesen drei Erfindern wird auch das Unterprogramm zugeschrieben.

\subsection{Woher kamen die Baukenntnisse?}

Kurz nach dem zweiten Weltkrieg machten Nachrichten über den bis anhin unbekannten riesigen US-Elektronenrechner Eniac die Runde. Schon vorher waren anscheinend Gerüchte über Geheimdienste nach Europa durchgesickert. Der Mammut erregte Argwohn, machte neugierig. Die Kriegswirren hatten einen erheblichen Nachholbedarf in vielen Bereichen verursacht. Der Informationsfluss war jahrelang überaus spärlich.

Zudem bahnte sich langsam ein Umbruch an. Die Elektronik bedrohte die Mechanik, die Digitaltechnik bedrängte die Analogtechnik. Der Wettbewerb zwischen Analogund Digitalrechnern dauerte noch dreißig Jahre. 


\section{Große Wissenslücken}

Die Anzahl der weltweiten Veröffentlichungen zur analogen und digitalen Rechentechnik von 1930 bis 1945 ist äußerst mager. Zu den aufkommenden programmgesteuerten Rechenmaschinen und den damit verbundenen Wissenszweigen gab es, von seltenen Ausnahmen abgesehen, weder Bücher noch Lehrveranstaltungen. Niemand hatte einen Überblick über den Stand der Forschung. So hielten sich denn manche europäische Wissenschaftler in den Vereinigten Staaten auf, um sich kundig zu machen. Ein Mekka war Princeton, wo u.a. Einstein und von Neumann lehrten. Viele wollten programmierbare Rechner anfertigen, aber es mangelte an grundlegenden Kenntnissen. Aus Gründen der Geheimhaltung blieb der Zugang zu manchen neuen Rechenanlagen gesperrt.

Die ersten bekannten Veröffentlichungen zum Relaisrechner Harvard mark 1/IBM ASCC und zum Röhrenrechner Eniac erschienen 1946. Die Kunde über die deutsche Zuse Z4 verbreitete sich ab 1947 nur langsam, der britische Colossus galt bis 1975 als Staatsgeheimnis (vgl. Bibliografie, Abschnitt „Frühe Veröffentlichungen“). Die vier erwähnten Maschinen hatten eine militärische Vergangenheit. Die beiden amerikanischen Maschinen wurden u.a. für Berechnungen zur Atombombe bzw. zur Wasserstoffbombe eingesetzt. Colossus diente fürs Brechen geheimer Funknachrichten. Und Zuse erhielt Kriegsaufträge.

\subsubsection{Lehrveranstaltungen}

Moore school lectures „Theory and techniques for design of electronic digital computers“(1946)

Von großer Bedeutung war die Lehrveranstaltung an der Universität von Pennsylvania in Philadelphia (vgl. Kasten):

\footnotetext{
Moore school lectures

An dieser wichtigsten Vorlesung zu digitalen Rechenautomaten kurz nach Kriegsende nahmen 28 Personen aus militärischen Einrichtungen, Universitäten, Industrie und Bundesverwaltung teil. Aus England besuchten Maurice Wilkes von der Universität Cambridge, Schöpfer des Rechners Edsac, und David Rees von der Universität Manchester (Manchester baby) den Anlass, ferner Douglas Hartree (als Vortragender). Aus den USA hatten sich u.a. Robert Everett vom MIT (Miterbauer des Whirlwind) und Claude Shannon von den Bell Labs eingeschrieben.

Die Vortragsliste umfasst die Namen fast aller damaligen Pioniere der Rechentechnik: Howard Aiken (Harvard mark 1/IBM ASCC), Arthur Burks (Eniac/IAS-Maschine), Presper Eckert (Eniac), Herman Goldstine (IAS-Maschine), Douglas Hartree (Integrieranlage), John Mauchly (Eniac), Jan Rajchman (Selectronröhre), Kite Sharpless (Eniac/Edvac), George Stibitz (Bell-Rechner), John von Neumann (IAS-Maschine), Samuel Williams (Bell-Rechner) (siehe Martin Campbell-Kelly; Michael Roy Williams (Hg.): The Moore school lectures, MIT press, Cambridge, Massachusetts, London/ Tomash publishers, Los Angeles, San Francisco 1985, Seiten XV-XVII).
} 
Nicht aufgeführt sind John Atanasoff (ABC) und Clair Lake (Harvard mark 1/IBM ASCC). Atanasoff war zu diesem Zeitpunkt in einem andern Bereich tätig. Die Harvard-Universität und IBM gingen nach einer Auseinandersetzung um Harvard mark 1/IBM ASCC getrennte Wege.

Es fehlen ferner die Europäer Thomas Flowers (Colossus, 1943), Alan Turing (Turingmaschine, 1936) und Konrad Zuse $(Z 4,1941)$. Colossus war geheim, die Z4 in einer Notunterkunft im Allgäu unterbracht. In Princeton (John von Neumann) und in New York (Bell Telephone Laboratories) kannte man Turing persönlich.

\section{Vortragsreihe in London}

In England bemühte sich das National physical laboratory (Teddington), das neue Wissen um die zukunftsträchtigen Digitalmaschinen weiterzugeben. James Wilkinson und Alan Turing hielten vom 12. Dezember 1946 bis 13. Februar 1947 in London eine Reihe von neun Vorträgen über den Entwurf des Elektronenrechners Ace (siehe Brian Jack Copeland (Hg.): Alan Turing's electronic brain, Oxford university press, Oxford 2012, Seiten 459-527). Daran nahm Thomas Kilburn teil, der mit Frederic Williams den Röhrenrechner der Universität Manchester schuf.

Arthur Porter erwähnt in seinen Lebenserinnerungen einen zehn Vorträge umfassenden Kurs über die Rechnerentwicklung, den Turing nach dem Krieg in den Labors der Post office research station in Dollis Hill durchgeführt hat. Nur fünf Personen waren dabei (siehe Arthur Porter: So many hills to climb, Beckham publications, Silver Spring, Maryland, 2004, Seiten 157-158).

\subsubsection{Veröffentlichungen}

Erst mit den folgenden Schriften sprang der zündende Funke für die weltweite Aufnahme des Rechnerbaus über (vgl. Kasten):

\section{Rechnerbau}

- John von Neumann: First draft of a report on the Edvac (1945) und

- Arthur Burks; Herman Goldstine; John von Neumann: Preliminary discussion of the logical design of an electronic computing instrument (1946).

Diese einflussreichen Arbeiten beschreiben den Aufbau von speicherprogrammierten Elektronenrechnern, den Von-Neumann-Maschinen. Ihre Grundzüge sind auch heute noch gültig.

Der Edvac-Bericht von 1945 trägt nur den Namen des Mathematikers John von Neumann. Die Streitfrage, wer was zu dieser Schrift beigetragen hat, dauert bis heute an. An den vorbereitenden Gesprächen wirkten u.a. John Mauchly und Presper Eckert mit.

Zwei grundlegende Beiträge stammen von Alan Turing (vgl. Kasten): 


\section{Universalmaschine}

- Alan Turing: On computable numbers, with an application to the Entscheidungsproblem (1936),

- Alan Turing: Proposals for development in the mathematics division of an automatic computing engine (1946).

Die Maschinenbauer haben diese beiden (nicht allgemein zugänglichen) Schriften offenbar kaum zur Kenntnis genommen. Unklar ist, was für Auswirkungen Turings Aufsatz von 1936 in Bletchley Park hatte.

Turing hatte seine Arbeit zur universellen Turingmaschine 1936/37 veröffentlicht. Dieses mathematische Gedankenmodell blieb aber zunächst ohne unmittelbar sichtbare Folgen. Turing fuhr im September 1936 für seine Doktorarbeit bei Alonzo Church nach Princeton.

\section{Überblick über den Stand der Dinge}

Anfang der 1950er Jahre erlaubten vor allem zwei Veröffentlichungen eine Übersicht über die neue Rechentechnik (vgl. Kasten):

\section{Gesamtdarstellungen}

- Engineering research associates, Inc.: High-speed computing devices (1950) und

- Heinz Rutishauser; Ambros P. Speiser; Eduard Stiefel: Programmgesteuerte digitale Rechengeräte (elektronische Rechenmaschinen) (1951).

\section{Programmierung}

Wegweisend für die Herstellung von Rechenplänen waren damals die folgenden Werke (vgl. Kasten):

\section{Programmherstellung}

- Herman Goldstine; John von Neumann: Planning and coding of problems for an electronic computing instrument (1947),

- Maurice Wilkes; David Wheeler; Stanley Gill: The preparation of programs for an electronic digital computer, with special reference to the Edsac and the use of a library of subroutines (1951),

- Heinz Rutishauser: Automatische Rechenplanfertigung bei programmgesteuerten Rechenmaschinen (1952).

Martin Campbell-Kelly hebt die Bedeutung von „Planning and coding of problems for an electronic computing instrument“ von Herman Goldstine und John von Neumann hervor:

„The Planning and coding reports were the key documents used by every group building a computer in the late 1940s and early 1950s.“ (siehe Martin Campbell-Kelly: From theory to practice: The invention of programming, 1947-51, in: Cliff B. Jones; John L. Lloyd (Hg.): Dependable and historic computing, Springer-Verlag, Heidelberg usw. 2011, Seiten 26-28). 
Die Abhandlung „Planning and coding“ war die Schlüsseldokumente, die von [fast] allen Gruppen benutzt wurden, die in den späten 1940er und den frühen 1950er Jahren einen Rechner bauten.

Campbell-Kelly beruft sich dabei auf eine Aussage von Donald Knuth und Luis Trabb Pardo: The early development of programming languages, in: Nicholas Constantine Metropolis; Jack Howlett; Gian-Carlo Rota (Hg.): A history of computing in the twentieth century, Academic press, New York, London usw. 1980, Seite 208). Nach Knuth und Trabb Pardo bildete der Bericht weltweit die Grundlagen der Programmtechnik.

Weitere Marksteine waren das Lehrbuch „The preparation of programs for an electronic digital computer, with special reference to the Edsac and the use of a library of subroutines“ von Maurice Wilkes, David Wheeler und Stanley Gill sowie Heinz Rutishausers Werk „Automatische Rechenplanfertigung bei programmgesteuerten Rechenmaschinen“.

\subsubsection{Bau der ersten Rechenmaschinen}

In der zweiten Hälfte der 1930er Jahre arbeiteten George Stibitz, Konrad Zuse und Howard Aiken an Relaisrechnern, und John Atanasoff baute einen Röhrenrechner. Zwei dieser Maschinen waren festprogrammiert, zwei lochstreifengesteuert, keine hat ein Speicherprogramm.

Die Zeit für die interne Programmspeicherung war offenbar noch nicht reif. Dafür kommen verschiedene Gründe in Frage: Man wusste nichts von Turings Vorschlägen oder hatte ihre Bedeutung nicht erkannt; man kam gar nicht auf die Idee des Speicherprogramms, oder es haperte bei der Umsetzung (Speichermangel). Auch der (unter hohem Zeitdruck entwickelte) elektronische Spezialrechner Colossus ließ sich nur extern über Steckkabel steuern. Alan Turing war durch seine Tätigkeit in Bletchley Park mit dem Colossus vertraut. Newman hatte seinerzeit Turings Arbeit zur Universalmaschine an der Universität Cambridge betreut.

Nicht sein Landsmann Alan Turing, sondern von Neumanns Bericht und die Lehrveranstaltung in Philadelphia hatten Maurice Wilkes aus Cambridge zur Entwicklung eines speicherprogrammierten Rechners veranlasst.

An der Universität Manchester begann der Bau eines Digitalrechners ebenfalls erst in der Nachkriegszeit. Nachdem Turing das National physical laboratory verlassen hatte, war er an dieser Hochschule tätig, wo auch sein ehemaliger Lehrer Max Newman lehrte. 


\subsubsection{Einführung in die Rechentechnik und Bestandsaufnahme (Überblick)}

Eduard Stiefel von der ETH Zürich und seine beiden Assistenten Heinz Rutishauser und Ambros Speiser hatten ab 1948 Studienaufenthalte in den USA, England und Deutschland gemacht. 1948 war Stiefel 39, Rutishauser war 30 und Speiser 26 Jahre alt. Ihre Erfahrungen gaben sie in einer bedeutsamen Schrift weiter, vgl. Heinz Rutishauser, Ambros Speiser, Eduard Stiefel: Programmgesteuerte digitale Rechengeräte (elektronische Rechenmaschinen), Birkhäuser Verlag, Basel 1951. Die Teile 1 und 2 erschienen bereits 1950 in der Zeitschrift für angewandte Mathematik und Physik, die Teile 3 und 4 folgten 1951.

Das Werk vermittelt - wahrscheinlich erstmals im deutschsprachigen Raum grundlegende Kenntnisse zum neuen Fachgebiet. Wie aus der Abhandlung hervorgeht, waren der Dreiergruppe folgende Rechner bekannt, die entweder fertig gestellt oder noch im Bau waren: Ace, ARC, Bark, mehrere Bell-Rechner, Binac, Edsac, Edvac, Eniac, drei Harvard-Rechner, IAS, IBM SSEC, Manchester baby, Seac, Univac, Z4. Sie erfuhren aber offensichtlich nichts von ABC, Colossus, Csirac, Mesm und Whirlwind. Ihre Zusammenstellung wurde angeblich auch ins Russische übersetzt.

In ihrer Arbeit geht das Dreigespann nicht auf das Zerwürfnis um den 1945 verteilten Edvac-Bericht (siehe John von Neumann: First draft of a report on the Edvac, in: William Aspray; Arthur Walter Burks (Hg.): Papers of John von Neumann on computing and computer theory, MIT press, Cambridge, Massachusetts, London 1987, Seiten 17-82) ein. Die Schrift fehlt im Literaturverzeichnis. Sie erwähnen aber eine 1947 erschienene, 42-seitige Abhandlung (vgl. Arthur Burks; Herman Goldstine; John von Neumann: Preliminary discussions of an electronic computing instrument, Institute for advanced study, Princeton, 2. Auflage 1947) sowie die wichtigen Werke aus den Jahren 1947/48 (vgl. Herman Goldstine; John von Neumann: Planning and coding for an electronic computing instrument, Band 1: 69 Seiten; Band 2: 68 Seiten; Band 3: 23 Seiten). Diese im Institute for advanced study in Princeton erstellten Berichte waren (damals) „nicht allgemein zugänglich“, eine Aussage, die auch für „Theory and techniques for design of electronic digital computers (Lectures given at the Moore school, July 8 to August 31, 1946)“ zutrifft. Die vier hektografierten Teile im Gesamtumfang von etwa 600 Seiten kamen 1946 bei der Moore school of electrical engineering der Universität von Pennslyvania in Philadelphia heraus.

Es fällt auf, dass Turings Aufsatz über die universelle Turingmaschine (1936) im Schriftenverzeichnis des Zürcher Trios nicht aufgeführt ist. Alan Turing wird (gemeinsam mit James Wilkinson) auf Seite 11 der Broschüre als Erbauer einer Maschine des National physical laboratory genannt. Diese Automatic calculating engine (Ace) ist in der „Übersicht über die im Betrieb oder im Bau befindlichen Rechenautomaten (Stand Dezember 1949)“ auf Seite 98 aufgeführt. Die Arbeit geht zwar auf die Speicherprogrammierung ein, Turing und von Neumann werden aber nicht erwähnt (siehe Heinz Rutishauser; Ambros Speiser; Eduard Stiefel: Programmgesteuerte digitale Rechenge- 
räte (elektronische Rechenmaschinen), Birkhäuser Verlag, Basel 1951, Seiten 19 und 53). Offenbar war Turings wegweisender Aufsatz damals kaum bekannt.

Im Werk von Rutishauser, Speiser und Stiefel werden mehrere Beiträge aus den Jahren 1947 bis 1950 angeführt, die in der Zeitschrift Mathematical tables and other aids to computation (MTAC) veröffentlicht wurden, so auch „The Zuse computer“ von Roger Johnson (1947). Die ETH Zürich hatte aber erst 1949 von der Zuse Z4 erfahren. Hingewiesen wird ferner auf ein technisches Sonderheft des „Wirtschaftspiegel“ vom März 1948: „Beschreibung des Rechengerätes von Zuse.“ (siehe Heinz Rutishauser; Ambros Speiser; Eduard Stiefel: Programmgesteuerte digitale Rechengeräte (elektronische Rechenmaschinen), Birkhäuser Verlag, Basel 1951, Seiten 101 bzw. 102). Diese Aufsätze waren wohl erst später zugänglich.

\subsection{Frühe Relais- und Röhrenrechner und ihre Nachfolger}

Im Folgenden wird versucht, ausgewählte Entwicklungslinien der ersten mechanischen, elektromechanischen und elektronischen Computer aus den Vereinigten Staaten, England und Deutschland darzustellen (vgl. Kasten). Die Zeitangaben sind selbst in den Originalschriften teilweise widersprüchlich.

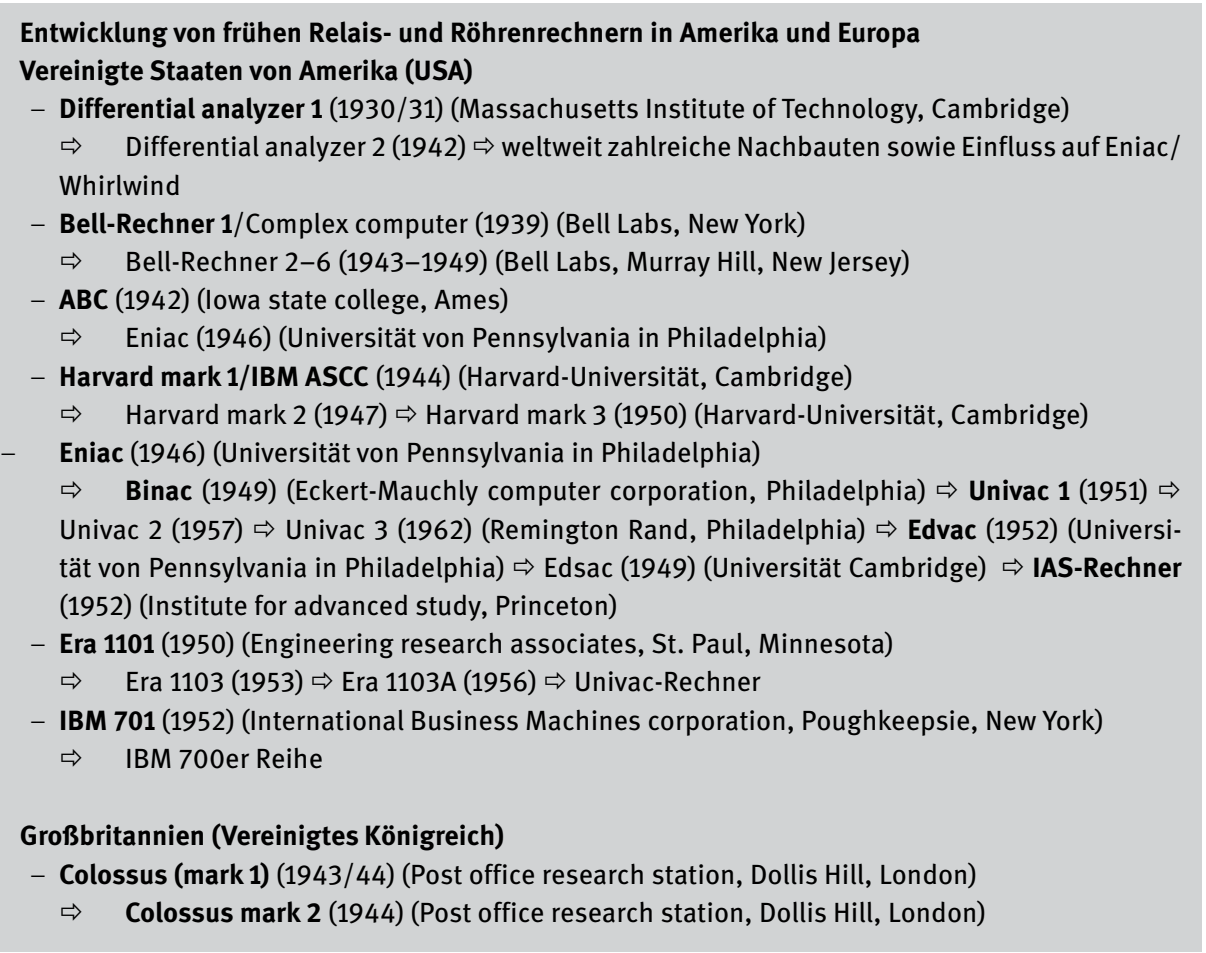


- SSEM (1948) (Universität Manchester)

$\Rightarrow \quad$ Manchester mark 1 (1949) $\Rightarrow$ Ferranti mark 1 (1951) $\Rightarrow$ Ferranti mark $1^{\star}(1953) \Rightarrow$ Ferranti mercury (1957) $\Rightarrow$ Ferranti-Reihe mit Pegasus, Perseus u.a. (Ferranti Ltd., Manchester)

- Edsac 1 (1949) (Universität Cambridge)

$\Rightarrow \quad$ Edsac 2 (1958) (Universität Cambridge) $\Rightarrow$ Leo 1 (1951) (John Lyons \& Co. Ltd., London) $\Rightarrow$ Leo 2 (1957), ferner Leo 3 (1962) (Leo computers Ltd., London)

- Pilot Ace (1950) (National physical laboratory, Teddington)

$\Rightarrow \quad$ Deuce 1 (1955) (English electric company Ltd., Stafford) $\Rightarrow$ Deuce 2 bzw. 2A (1955/57), ferner Mosaic $\Rightarrow$ Ace (1958) (National physical laboratory, Teddington), Mosaic und Bendix

- ARC 2 (1947) (Birkbeck college, Universität London) $\Rightarrow \quad \mathrm{SEC}(1950) \Rightarrow$ Apec (1952) $\Rightarrow$ Hec 1 (1951) $\Rightarrow$ Hec 2M/BTM 1200 (1955) $\Rightarrow$ Hec 4/BTM 1201 (1956) (British tabulating machine Co., Letchworth)

\section{Deutschland}

- Z3 (1941) (Konrad Zuse, Berlin)

$\Rightarrow \quad$ Z4 (1945) $\Rightarrow$ Z5 (1952/53) (Zuse KG, Neukirchen, später Bad Hersfeld).

\section{Hinweise}

Der eindrückliche, aber schwerfällige, stecktafelgesteuerte Großrechner Eniac ohne Speicherprogramm war kein zukunftsweisendes Vorbild, sondern vielmehr eine Sackgasse. Die „Nachfolger“ weichen in ihrem Aufbau stark von ihrem Vorgänger ab. Eniacs Mängel spornten aber zur Suche nach besseren Lösungen an. Der IAS-Rechner (Princetonmaschine) war Ausgangspunkt mancher in- und ausländischer Nachbauten. In einigen Fällen waren die Nachahmer schneller als ihre Vorbilder (z.B. war Edsac vor Edvac fertig). ABC beeinflusste offenbar den Bau des Riesenrechners Eniac. Die Maschine Era 1101 hieß ursprünglich Atlas 1 (1950). Für Deuce 2 wird als Baujahr ebenfalls 1958 erwähnt, Leo 3 wird auch mit 1963 datiert.

\subsection{Beweggründe für den Rechnerbau}

Welches waren die Beweggründe für den Bau von mathematischen Maschinen? Ein erheblicher Rechenbedarf ist schon früh in den Bereichen Sternkunde, Seefahrt und Vermessungswesen festzustellen. Später kommen das Versicherungswesen, die Nachrichtentechnik, die Ermittlung von Geschoßbahnen und das Knacken von Geheimmeldungen hinzu. Die Nachfrage war also ziviler wie auch militärischer Art. Auch die Wissenschaft (z.B. Mathematik, Physik), die Wirtschaft (Handel, Banken, Steuerwesen) und die Statistik (Volkszählung) beflügelten zunehmend den Maschinen- und Instrumentenbau sowie die Uhrmacherkunst. Jahrhundertelang reichten aber vergleichsweise kleine Rechengeräte aus. Sie mussten von Hand betrieben werden, etwa mit Hilfe einer Kurbel. Elektrischer Strom stand noch nicht zur Verfügung. Charles Babbage hatte für seine analytische Rechenmaschine sogar an die Dampfkraft gedacht. Hauptsächliche Wurzeln der Informatik sind die numerische Mathematik und das Ingenieurwesen. 
Die wichtigste Triebfeder war wohl das Grundbedürfnis, sich vom mühevollen Rechnen zu befreien. Die Maschinen trugen überdies dazu bei, dass bisher ausgeschlossene zeitraubende Fragestellungen angepackt werden konnten. Die Beschäftigung mit dem maschinellen Rechnen erlaubte es zudem, neue wissenschaftliche Erkenntnisse zu gewinnen und neuartige Rechenverfahren auszuprobieren. Die Vermarktung von mathematischen Maschinen und Werkzeugen versprach finanziell einträgliche Geschäfte. Der Besitz moderner Computer steigerte auch die Macht.

\section{Der erste Großrechner}

Viele anspruchsvolle mathematische Aufgabenstellungen ließen sich wegen des ungeheuren Rechenaufwands mit herkömmlichen Rechenschiebern und mechanischen Tischrechenmaschinen nicht lösen. So schuf Vannevar Bush am Massachusetts Institute of Technology (Cambridge) den ersten Großrechner, eine mächtige analoge Integrieranlage (1930/31). Sie diente als Vorlage für viele Nachbauten rund um die Erde, z.B. durch Douglas Hartree von der Universität Manchester.

Nachholbedarf in Europa

Ab Mitte der 1940er Jahre erschienen in der Presse Berichte über leistungsfähige programmierbare digitale Relais- und Röhrenrechner, die an der Harvard-Universität (Harvard mark 1/IBM ASCC, 1944) und der Universität von Pennsylvania in Philadelphia (Eniac, 1946) in Betrieb standen. Um den Anschluss nicht zu verpassen, begannen europäische Forschungseinrichtungen mit dem Eigenbau von solchen (allerdings weniger kostspieligen) Rechenanlagen. Vor allem in Großbritannien kam es zu einer Aufholjagd. Es entbrannte ein Wettstreit um den ersten speicherprogrammierten Elektronenrechner. 1948 kamen der IBM SSEC (USA) und das Manchester baby (England) zur Welt. Programmgesteuerte elektronische Rechenautomaten (Ferranti mark und Univac) wurden erst seit 1951auf dem Markt angeboten.

\section{Elektronikkenntnisse}

Manche Wegbereiter, z.B. Presper Eckert, Maurice Wilkes und Frederic Williams, hatten im zweiten Weltkrieg Erfahrungen mit der Radartechnik gemacht und sich so Kenntnisse der Elektronik angeeignet. Dieses Wissen war auch für die Entwicklung von Quecksilber- und elektrostatischen Speichern hilfreich.

\section{Beweggründe ausgewählter Pioniere}

Es folgen einige Beispiele, welche die unterschiedlichen Beweggründe für den Bau von Rechengeräten zeigen sollen:

\section{Howard Aiken}

Der Physiker Aiken war 1938 auf der Suche nach einem geeigneten Hilfsmittel, um wissenschaftliche Berechnungen für seine Doktorarbeit durchzuführen. 


\section{Jakob Amsler}

Um die anspruchsvolle Berechnung von Flächen zu erleichtern, schuf der Mathematiker Amsler 1854 das analoge Polarplanimeter.

\section{John Atanasoff}

Der elektronische Spezialrechner ABC (1942) des Physikers Atanasoff war für die Lösung von Gleichungssystemen bestimmt.

\section{Charles Babbage}

Fehlerhafte mathematische Tafelwerke sollen den Mathematiker Babbage um 1822 zum Entwurf einer Differenzenmaschine angespornt haben. Nach ihrem Misserfolg machte er sich Gedanken zu einem programmgesteuerten Vielzweckgerät, der analytischen Maschine (1834).

\section{Vannevar Bush}

Für die Lösung von umfangreichen Differenzialgleichungen konstruierte der Ingenieur Bush eine mechanische Integrieranlage (1930/31).

\section{Presper Eckert und John Mauchly}

Der Physiker Mauchly und der Ingenieur Eckert wollten eine digitale Integrieranlage schaffen. Eniac (1946) entstand im Auftrag des US-Heers ursprünglich als Spezialmaschine für ballistische Berechnungen. In der Absicht, leistungsfähige Elektronenrechner zu entwickeln und zu verkaufen, gründeten die beiden Forscher ein eigenes Rechenbauunternehmen. Es wurde später von Remington Rand übernommen. Die Univac-Maschinen wurden weltweit mit Erfolg vermarktet. Mauchly schied später aus.

\section{Thomas Flowers}

Um die deutschen Geheimmeldungen zu entziffern, schuf der Ingenieur Flowers 1943 in wenigen Monaten den Röhrenrechner Colossus, der in Bletchley Park gegen die Lorenzmaschine eingesetzt wurde.

\section{Curt Herzstark}

Die Nachfrage nach einer leichten, handlichen mechanischen Taschenrechenmaschine veranlasste den Ingenieur Herzstark zur Fertigung der Curta (1948-1971).

Herman Hollerith

Die langwierige Auswertung der amerikanischen Volkszählung von 1880 bildete für den Ingenieur Hollerith den Anreiz zur Entwicklung von Lochkartenmaschinen. Zehn Jahre später bestanden sie ihre Feuertaufe bei der nächsten Volkszählung (1890).

\section{Gottfried Wilhelm Leibniz}

Der Universalgelehrte Leibniz erfand das Sprossenrad und auch die Staffelwalze. Neben der dezimalen Vierspeziesmaschine (1673) entwarf er eine binäre „Kugelmaschine“ und eine Verschlüsselungsmaschine. Er erleichterte der Nachwelt die Rechenarbeit erheblich. 


\section{Max Newman}

Nach den Erfahrungen mit dem elektronischen Spezialrechner Colossus in Bletchley Park (1945) war es ein Anliegen des Mathematikers Newman, einen elektronischen Digitalrechner auf die Beine zu stellen und seine Leistungsfähigkeit zu nutzen. Das Vorhaben wurde von Frederic Williams und Thomas Kilburn 1948 in die Tat umgesetzt.

William Oughtred

Um die Multiplikation und die Division zu vereinfachen, erfand der Mathematiker Oughtred um 1622 den logarithmischen Rechenstab.

\section{Blaise Pascal}

Der Mathematiker Pascal baute für seinen Vater, der sich mit Steuerabrechnungen abplagen musste, zahlreiche Zweispeziesmaschinen (Addierer/Subtrahierer) (ab 1642).

\section{Wilhelm Schickard}

Der vielseitige Gelehrte Schickard wollte seinen Freund Johannes Kepler bei der Berechnung von astronomischen Tabellen unterstützen (1623).

\section{Jean-Baptiste Schwilgué}

Der Bau der astronomischen Uhr des Straßburger Münsters setzte umfangreiche Berechnungen voraus. Für die Fertigung der Zahnräder entwickelte der Uhrmacher Schwilgué einen „Prozessrechner“ (um 1830).

\section{George Stibitz}

Für die Nachrichtentechnik mussten die Bell Labs mit Tischrechenmaschinen aufwendige Berechnungen (vor allem Multiplikation und Division) komplexer Zahlen durchführen. Der Mathematiker Stibitz fand eine Lösung mit einem Relaisrechner (1939).

\section{Charles-Xavier Thomas}

Der Versicherungskaufmann und Versicherungsunternehmer Thomas wollte mit seinem Arithmometer (1820), einer mechanischen Vierspezies-Staffelwalzenmaschine, die mühselige Rechnerei erleichtern.

\section{Leonardo Torres Quevedo}

Ziel des spanischen Ingenieurs Torres Quevedo war u.a. die Verwirklichung von Babbages Traum. Zunächst konstruierte er eine algebraische Maschine (1893), dann einen Schachautomaten (1912) und schließlich einen elektromechanischen Rechner, der mit einer Schreibmaschine gekoppelt war (1920).

\section{Alan Turing}

David Hilberts Entscheidungsproblem regte den Mathematiker Turing an, ein mathematisches Gedankenmodell einer universellen Rechenmaschine zu schaffen (1936). Der Wunsch, eine praktisch brauchbare speicherprogrammierte Maschine herzustellen, war naheliegend, insbesondere nach den Erfahrungen mit dem Röhrenrechner 
Colossus in Bletchley Park. Turing entwarf den Elektronenrechner (Ace). Er wechselte aber schon vor seiner Fertigstellung (1950) an die Universität Manchester, weil es bei der Umsetzung zu erheblichen Verzögerungen kam.

\section{John von Neumann}

Die Berechnungen für den Bau der Atombombe waren äußerst zeitraubend. Die Beschäftigung mit dem schwerfälligen Röhrenrechner Eniac veranlasste den Mathematiker von Neumann zum Entwurf einer Arbeit über speicherprogrammierte Maschinen (1945) und zur Fertigung der elektronischen Princetonmaschine (1952).

\section{Maurice Wilkes}

Die Abhandlung über den Von-Neumann-Rechner und der Besuch der Vortragsreihe an der Universität von Pennsylvania in Philadelphia gaben für den Mathematiker Wilkes den Ausschlag für die Fertigung des Röhrenrechners Edsac (1949). Er erhielt von der Universität Cambridge den Auftrag, das mathematische Labor mit einem Rechendienst auszustatten. Schon früher hatte er die hauseigene analoge Integrieranlage für Berechnungen verwendet.

\section{Konrad Zuse}

Der Bauingenieur Zuse wollte die mühseligen statischen Berechnungen loswerden und suchte dazu einen elektromechanischen Gehilfen. Er erkannte bald, dass sich Digitalrechner für vielfältige Zwecke nutzbar machen lassen. Ergebnis war der Relaisrechner Z3 (1941).

\section{Programmiermaschine}

Das beschwerliche Programmieren brachte den Mathematiker Heinz Rutishauser auf den Gedanken, für das Übersetzen von Anweisungen in die Maschinensprache den Computer einzusetzen (1951).

\section{Automaten für Fürstenhöfe}

Mit der Entwicklung „programmierbarer“ Schreibautomaten befassten sich die Uhrmacher Friedrich Knaus (allesschreibende Wundermaschine, 1760) und Pierre JaquetDroz (Schriftsteller, 1772). Solche Kunstwerke wurden besonders an den Fürstenhäusern vorgeführt. Leonardo da Vinci entwarf einen mechanischen Ritter (1495), einen mechanischen Löwen (1515) und einen selbstfahrenden Wagen (1478). Herons Automatentheater (1. Jh.) diente ebenfalls der Unterhaltung.

\subsection{Wer war an der Entwicklung des Computers beteiligt?}

Unzählige Forscher und manche Programmiererinnen haben an der Entwicklung der programmgesteuerten Rechenautomaten mitgewirkt. Die Frage, wer den Computer erfunden hat, lässt sich daher nicht eindeutig beantworten. 


\subsubsection{Charles Babbage}

Der englische Gelehrte Charles Babbage hat einen Spezialrechner - die Differenzenmaschine - und einen Universalrechner - die analytische Maschine - entworfen. „Analytisch“ bedeutet in diesem Zusammenhang programmgesteuert.

Schon Johann Helfrich Müller hatte sich mit der Differenzenmaschine befasst. Mit Hilfe von Unterschieden sollten mathematische Tafeln berechnet werden. Babbages Geräte blieben unvollendet. Seine Erkenntnisse wurden jedoch von den Schweden Pehr Georg Scheutz und Edvard Raphael Scheutz aufgegriffen.

Für die analytische Maschine war - nach dem Vorbild des Jacquard-Webstuhls - eine Lenkung durch ein äußeres Programm vorgesehen. Die Lochkarten- und Lochbandsteuerung wurde allerdings nicht von Joseph-Marie Jacquard, sondern von seinen französischen Landsleuten Basile Bouchon, Jean-Baptiste Falcon und Jacques Vaucanson ersonnen.

Die analytische Maschine, die Babbage ab 1834 entwickelte, wies bereits entscheidende Merkmale moderner Rechenautomaten auf: Steuerwerk, Rechenwerk, Speicher, Programmsteuerung. Sein Vorhaben war eine bahnbrechende Konstruktion. Bis zur Verwirklichung sollten noch 100 Jahre vergehen. Weil die Maschinen nie (fertig) gebaut wurden, kann man Charles Babbage kaum als den Erfinder des Computers bezeichnen, wohl aber als Vorläufer.

\subsubsection{Alan Turing}

Der englische Logiker Alan Turing hat 1936 in einem Aufsatz zur Berechenbarkeit ein wegweisendes mathematisches Modell, die Turingmaschine, vorgestellt. $\mathrm{Zu}$ seiner Zeit waren Computer noch (rechnende) Menschen. Seine Abhandlung beschreibt ein theoretisches, gedankliches Gerät. Es besteht u.a. aus einem unendlich langen Band und lässt sich deshalb in dieser Form nicht umsetzen. Die Handhabung seines Modells ist beschwerlich.

Turing hat im zweiten Weltkrieg zusammen mit Gordon Welchman einen elektromechanischen Relaisrechner gebaut, der in Anlehnung an eine polnische Vorgängermaschine „Bombe“ genannt wurde. Er diente für das Knacken der Funksprüche, die mit Unterstützung der deutschen Verschlüsselungsmaschine Enigma erzeugt wurden.

Von der Turingmaschine bis zu einem praktisch brauchbaren Digitalrechner war es noch ein weiter Weg. Turing schlug 1945 in einem Bericht den Bau des Elektronenrechners Ace (Automatic computing engine) vor. Seine Vorstellungen, die von der üblichen Bauweise von Neumanns abweichen, gelten als elegant und schlank, haben sich aber nicht durchgesetzt. 1950 lief eine veränderte, abgespeckte Ausführung erstmals, Turing war allerdings daran nicht mehr beteiligt. An der Universität Manchester 
war bereits zwei Jahre vorher ein ähnlicher speicherprogrammierter Röhrenrechner zur Welt gekommen.

Weil die universelle Turingmaschine nur eine Papiermaschine ist und sich im Alltag nicht einsetzen lässt, kann man Alan Turing wohl nicht als den Schöpfer des heutigen Digitalrechners betrachten. Zudem müsste man die fast gleichzeitig entstandenen Arbeiten von Alonzo Church und Emil Leon Post in die Überlegungen mit einbeziehen. Ihre Ansätze gelten als gleichwertig.

Es ist also umstritten, ob Alan Turing den Computer erfunden hat:

„Turing did not invent the computer, nor did his 1936 paper lead to the invention of the computer.“ (siehe Edgar Graham Daylight: Turing tales, Lonely Scholar, Geel (Belgien), 2016, Seite 187).

Turing hat den Computer nicht erfunden, seine Abhandlung von 1936 hat auch nicht zur Erfindung des Computers geführt.

Dieser Frage wird im folgenden Aufsatz ausführlich nachgegangen:

Thomas Haigh: Historical reflections. Actually, Turing did not invent the computer, in: Communi-

cations of the ACM, Band 57, 2014, Heft 1, Seiten 36-41.

\subsubsection{John von Neumann}

Der ungarisch-amerikanische Mathematiker John von Neumann hat 1945 grundlegende Einsichten über die Gestaltung von Elektronenrechnern veröffentlicht. Es ist freilich bis heute heftig umstritten, wer als erster den Einfall des Speicherprogramms (Aufbewahren der Daten sowie der Anweisungen im gleichen inneren Hauptspeicher) hatte: Alan Turing, Konrad Zuse, Presper Eckert, John Mauchly, John von Neumann oder andere. Auch die Trennung zwischen mehreren Baueinheiten - Rechenwerk, Steuerwerk, Speicherwerk, Eingabe- und Ausgabegerät - war nicht neu. Solche Gedanken hatten beispielsweise schon Charles Babbage und Konrad Zuse.

Von Neumann hat die Entwicklungsgeschichte des Computers maßgeblich mitgeprägt, etwa 1946 durch eine maßgebliche Abhandlung (vgl. Arthur Walter Burks; Herman Goldstine; John von Neumann: Preliminary discussion of the logical design of an electronic computing instrument, The Institute for advanced study, Princeton, 2. Auflage 1947). Der IAS-Rechner (Institute for advanced study) war zwar vergleichsweise spät fertig, bewirkte aber manche Nachbauten. Von Neumann ist allerdings nicht der Vater der programmgesteuerten Rechenmaschine. Denn schon vor seiner Einflussnahme gab es mehrere betriebsfähige Relais- und Röhrenrechner: Bells Complex computer, Zuse Z3, ABC (Atanasoff-Berry computer), Colossus, Harvard mark 1 /IBM ASCC, Eniac. 


\subsubsection{Konrad Zuse}

Der deutsche Bauingenieur Konrad Zuse brachte 1941 seinen Relaisrechner Z3 (damals noch V3 genannt, V = Versuchsmodell) zum Laufen. Er gilt als erster „frei“ programmierbarer, programmgesteuerter Digitalrechner, arbeitete mit dem Zweiersystem und mit Gleitkommadarstellung. Das Relaisgerät war jedoch nicht speicherprogrammiert und kannte zudem keine bedingten Sprünge. Die Z3 war wie der - ebenfalls elektromechanische - Harvard mark 1/IBM ASCC ein Universalrechner, im Unterschied zu den frühen elektronischen Spezialrechnern ABC und Colossus.

Im Gegensatz zur unvollendeten analytischen Maschine von Babbage und zu Turings mathematischem Gedankenmodell war die Zusemaschine praktisch nutzbar. Sie wurde über Lochstreifen, also durch ein äußeres Programm, gesteuert. Konrad Zuse ist daher einer der Erfinder der programmgesteuerten Rechenmaschine. Seine Patentanmeldung wurde „mangels Erfindungshöhe“ abgelehnt.

\subsubsection{Weitere mögliche Erfinder}

An der Schaffung des mechanischen und elektronischen Digitalrechners waren u.a. auch Howard Aiken, John Atanasoff, Thomas Flowers und George Stibitz beteiligt. Hinzu kommen Presper Eckert und John Mauchly, deren Patent nachträglich aufgehoben wurde.

\subsubsection{Wer hat welche Rechenmaschine erfunden?}

Mit der folgenden Zusammenstellung (vgl. Tab. 1.4) wird versucht, einen Überblick über die Erfinder bedeutender Rechenmaschinen zu vermitteln. Es wird unterschieden zwischen den Pionieren, welche die Geräte als erste ausgedacht bzw. als erste gebaut haben. Als wirkliche Erfinder kommen am ehesten Personen in Frage, die beide Eigenschaften erfüllen. Die Übersicht erhebt keinen Anspruch auf Vollständigkeit. Turing und von Neumann haben je einen frühen speicherprogrammierten Rechner entworfen und (mit)gebaut (Pilot Ace bzw. Princetonmaschine). 
Tab. 1.4: Viele Pioniere haben zur Erfindung von Rechenmaschinen beigetragen

\begin{tabular}{|c|c|c|c|}
\hline Kennzeichen & $\begin{array}{l}\text { Wer hat die } \\
\text { Rechenmaschine } \\
\text { erdacht? }\end{array}$ & $\begin{array}{l}\text { Wer hat die } \\
\text { Rechenmaschine erst- } \\
\text { mals gebaut? }\end{array}$ & $\begin{array}{l}\text { Wer hat die } \\
\text { Rechenmaschine } \\
\text { erfunden } \\
\text { (erdacht und gebaut)? }\end{array}$ \\
\hline $\begin{array}{l}\text { Analogrechner } \\
\text { (Spezialmaschine) }\end{array}$ & & & $\begin{array}{l}\text { unbekannter Grieche } \\
\text { (Räderwerk } \\
\text { von Antikythera) } \\
\text { Jean-Baptiste Schwilgué } \\
\text { (Kirchenrechner) }\end{array}$ \\
\hline $\begin{array}{l}\text { Analogrechner } \\
\text { (Integrieranlage) }\end{array}$ & $\begin{array}{l}\text { William Thomson } \\
\text { (mechanisch) }\end{array}$ & & $\begin{array}{l}\text { Vannevar Bush } \\
\text { (mechanisch), } \\
\text { Helmut Hoelzer } \\
\text { (elektronisch), } \\
\text { George A. Philbrick } \\
\text { (elektronisch) }\end{array}$ \\
\hline $\begin{array}{l}\text { Digitalrechner, } \\
\text { festprogrammiert }\end{array}$ & & & $\begin{array}{l}\text { Wilhelm Schickard } \\
\text { (mechanisch, } \\
\text { Mehrspeziesmaschine), } \\
\text { Blaise Pascal } \\
\text { (mechanisch, } \\
\text { Zweispeziesmaschine), } \\
\text { Gottfried Wilhelm Leibniz } \\
\text { (mechanisch, } \\
\text { Vierspeziesmaschine), } \\
\text { Charles-Xavier Thomas } \\
\text { (mechanisch, } \\
\text { Vierspeziesmaschine), } \\
\text { Curt Herzstark } \\
\text { (mechanisch, } \\
\text { Vierspezies- } \\
\text { Taschenrechenmaschine), } \\
\text { George Stibitz } \\
\text { (elektromechanisch), } \\
\text { John Atanasoff } \\
\text { (elektronisch) }\end{array}$ \\
\hline $\begin{array}{l}\text { Digitalrechner, } \\
\text { stecktafelgesteuert }\end{array}$ & & & $\begin{array}{l}\text { Herman Hollerith } \\
\text { (Lochkartenmaschine), } \\
\text { Thomas Flowers } \\
\text { (elektronisch, } \\
\text { Spezialrechner), } \\
\text { John Mauchly/ } \\
\text { Presper Eckert } \\
\text { (elektronisch, } \\
\text { Universalrechner) }\end{array}$ \\
\hline
\end{tabular}




\begin{tabular}{llll}
\hline Wer hat die Rechenmaschine erfunden? & & \\
\hline Kennzeichen & $\begin{array}{l}\text { Wer hat die } \\
\text { Rechenmaschine } \\
\text { erdacht? }\end{array}$ & $\begin{array}{l}\text { Wer hat die } \\
\text { Rechenmaschine erst- } \\
\text { mals gebaut? }\end{array}$ & $\begin{array}{l}\text { Wer hat die } \\
\text { Rechenmaschine } \\
\text { erfunden } \\
\text { (erdacht und gebaut)? }\end{array}$ \\
\hline $\begin{array}{l}\text { Digitalrechner, } \\
\text { programmgesteuert }\end{array}$ & $\begin{array}{l}\text { Charles Babbage } \\
\text { (mechanisch) }\end{array}$ & & $\begin{array}{l}\text { Konrad Zuse } \\
\text { (elektromechanisch), } \\
\text { Howard Aiken }\end{array}$ \\
\hline $\begin{array}{l}\text { Digitalrechner, } \\
\text { speicher- } \\
\text { programmiert }\end{array}$ & $\begin{array}{l}\text { Alan Turing } \\
\text { (mechanisch und } \\
\text { elektronisch), } \\
\text { John von Neumann } \\
\text { (elektronisch) }\end{array}$ & $\begin{array}{l}\text { (elektromechanisch) } \\
\text { elektronisch), } \\
\text { Frederic Williams } \\
\text { (elektronisch), }\end{array}$ & $\begin{array}{l}\text { John Mauchly/ } \\
\text { Presper Eckert } \\
\text { (elektronisch, } \\
\text { Universalrechner) }\end{array}$ \\
\hline
\end{tabular}

(C) Bruderer Informatik, CH-9401 Rorschach 2020

\section{Anmerkungen}

In Spanien wird auch Leonardo Torres Quevedo als Erfinder des Computers gehandelt. Ob die Turingmaschine speicherprogrammiert ist, ist umstritten.

\subsection{Wo befindet sich die Wiege des Computers?}

Der heutige Digitalrechner kam in der ersten Hälfte der 1940er Jahre unabhängig in drei verschiedenen Ländern zur Welt: Deutschland, England und USA. In Berlin war der Computer das Werk einer Einzelperson, anderswo waren Hochschulen, staatliche Betriebe oder die Industrie beteiligt. Der deutsche Erfinder war aus politischen Gründen weitgehend von der Außenwelt abgeschnitten. Die Briten arbeiteten unter größter Geheimhaltung, ging es doch um das Knacken verschlüsselter Funksprüche. Innerhalb der Vereinigten Staaten gab es hingegen teilweise einen Meinungsaustausch. Der heutige Digitalrechner hatte viele Geburtshelfer (vgl. Tab. 1.5).

Tab. 1.5: Wurzeln des heutigen Computers im 19. und 20. Jahrhundert

\begin{tabular}{llll}
\hline Mitfinder des Computers & & & \\
Name & Land & Jahr & Maschine \\
\hline Charles Babbage & England & 1834 & analytische Maschine (unvollendet) \\
Leonardo Torres Quevedo & Spanien & 1920 & analytische Maschine (Versuchsgerät) \\
George Stibitz & USA & 1939 & Complex computer \\
Konrad Zuse & Deutschland & 1941 & Z3
\end{tabular}




\begin{tabular}{llll}
\hline Mitfinder des Computers & & & \\
Name & Land & Jahr & Maschine \\
\hline John Atanasoff & USA & 1942 & Atanasoff-Berry-Rechner \\
Thomas Flowers & England & 1943 & Colossus 1 \\
Howard Aiken & USA & 1944 & Harvard mark 1/IBM ASCC \\
\hline
\end{tabular}

(C) Bruderer Informatik, $\mathrm{CH}-9401$ Rorschach 2020

\section{Anmerkung}

Der Computer ist eine von vielen Erfindungen, die unabhängig an mehreren Orten gemacht wurden.

Der Computer kam in drei Ländern zur Welt (vgl. Tab. 1.6).

Tab. 1.6: Herkunft des Computers

\begin{tabular}{llll}
\hline \multicolumn{4}{ll}{ Wiege des programmgesteuerten Digitalrechners } \\
Land & Name & Jahr & Maschine \\
\hline Deutschland & Konrad Zuse & 1941 & Zuse Z3 \\
England & Thomas Flowers & 1943 & Colossus 1 \\
USA & George Stibitz & 1939 & Complex computer \\
& John Atanasoff & 1942 & Atanasoff-Berry-Rechner \\
& Clifford Berry & & \\
& Howard Aiken & 1944 & Harvard mark 1/IBM ASCC \\
& Clair Lake & & \\
\hline
\end{tabular}

(C) Bruderer Informatik, CH-9401 Rorschach 2020

\section{Anmerkungen}

Der Computer soll - wenn auch deutlich später (1950) - unabhängig auch in der ehemaligen Sowjetunion entstanden sein: Mesm von Sergei Lebedew.

Die ersten nordamerikanischen Entwicklungszentren für programmgesteuerte Digitalrechner waren das Iowa state college, Ames (heute Staatsuniversität), die Bell Telephone Laboratories (damals in New York City) sowie die Harvard-Universität (Cambridge, Massachusetts) und die Universität von Pennsylvania in Philadelphia, ferner das Massachusetts Institute of Technology in Cambridge, das Institute for advanced study, Princeton, sowie die Columbia-Universität, New York. Manche Maschinen trugen die Bezeichnung „mark“, Kürzel Mk., was „Modell“ bedeutet.

$\mathrm{Zu}$ den Wegbereitern des heutigen Digitalrechners gehören Turing und von Neumann (vgl. Tab. 1.7). 
Tab. 1.7: Schöpfer der theoretischen Voraussetzungen für den Computer

\begin{tabular}{llll}
\hline \multicolumn{4}{l}{ Wer hat die theoretischen Grundlagen geschaffen? } \\
Name & Land & Jahr & Thema \\
\hline Alan Turing & England & 1936 & universelle Turingmaschine \\
John von Neumann & USA & 1945 & Von-Neumann-Rechner \\
\hline
\end{tabular}

(C) Bruderer Informatik, CH-9401 Rorschach 2020

\section{Anmerkungen}

Neben Turing und von Neumann gibt es viele weitere Forscher, welche die theoretischen Voraussetzungen für die modernen Rechenautomaten geschaffen haben. So hat sich auch Zuse mit solchen Fragen befasst (Dualsystem, Gleitkomma, logistisches Gerät). Die Wurzeln der Von-Neumann-Architektur reichen bis ins 19. Jahrhundert (Charles Babbage) zurück.

Wichtige Grundzüge der heutigen Digitalrechner werden in den folgenden Abhandlungen vorgestellt:

- Alan Mathison Turing (Universität Cambridge):

On computable numbers, with an application to the Entscheidungsproblem (Veröffentlichung am 30. November/23. Dezember 1936),

Vorstellung der universellen Turingmaschine;

- John von Neumann (Institute for advanced study, Princeton):

First draft of a report on the Edvac

(Verbreitung am 30. Juni 1945),

Vorstellung des speicherprogrammierten Universalrechners.

Mit der Entstehung des Computers werden viele weitere Namen in Verbindung gebracht (vgl. Tab. 1.8). Hier handelt es sich jedoch nicht um Ersterfinder.

Tab. 1.8: Konstrukteure von Röhrenrechnern

\begin{tabular}{lll}
\hline \multicolumn{2}{l}{ Erbauer von Elektronenrechnern } & \\
Name & Jahr & Maschine \\
\hline John Presper Eckert & 1946 & Eniac \\
Thomas Kilburn & 1948 & Manchester baby \\
John William Mauchly & 1946 & Eniac \\
Maurice Vincent Wilkes & 1949 & Edsac \\
Frederic Calland Williams & 1948 & Manchester baby \\
\hline
\end{tabular}

(C) Bruderer Informatik, CH-9401 Rorschach 2020 


\subsection{Welcher Zeitpunkt ist bei einer Erfindung maßgebend?}

Welcher Zeitpunkt ist richtig? Diese Frage stellt sich beim Verfassen von Zeittafeln und der Ermittlung von Rangfolgen. Die verfügbaren Daten sind häufig widersprüchlich, ungenau und unvollständig. Die Angaben lassen sich daher nur schwer vergleichen. Was ist bei der Erfindung einer Rechenmaschine entscheidend:

- der Erstlauf, der Beginn des Versuchsbetriebs oder die Aufnahme des Dauerbetriebs,

- die erste private oder öffentliche Vorführung (des Versuchsmodells oder der praktisch brauchbaren Anlage),

- die Produktankündigung in den Medien,

- die erste Vorführung auf einer Fachmesse,

- die Lieferung der ersten Maschine an die Kundschaft,

- die Einrichtung der Anlage beim Nutzer,

- die Inbetriebnahme des Geräts,

- die Einweihung/Enthüllung des Computers?

Die Beobachtungen machen deutlich, dass die Erfinder und Hersteller aus Wettbewerbsgründen dazu neigen, für ein Gerät den Termin des Erstlaufs zu nennen, unabhängig vom Reifegrad der Maschine. Manchmal dauert es noch mehrere Jahre, bis die Anlage im Alltag verwendbar ist. Zudem werden Automaten oft schrittweise in Betrieb genommen.

\subsection{Wer gewann den Wettlauf?}

Superlative sind in der Praxis allgegenwärtig und beliebt, in der Geschichtswissenschaft jedoch heikel. Im Alltag zählen vor allem Höchst- und Bestleistungen sowie Ersterfindungen. Bewertungen und Ranglisten können je nach den angewandten Maßstäben und Auswahlkriterien stark voneinander abweichen.

\section{Auswahlkriterien}

Es gibt mehrere „erste“ Maschinen. Die Antwort nach dem Ursprung des Computers hängt davon ab, was man unter einer solchen Rechenmaschine versteht und welcher Entwicklungszeitpunkt zugrunde gelegt wird. Was für Geräte sollen in die Beurteilung mit einbezogen werden:

- nur Digital- oder auch Analogrechner,

- nur elektronische oder auch elektromechanische oder gar mechanische Geräte,

- nur speicherprogrammierte, programmgesteuerte oder auch lochstreifen-, lochkarten- und stecktafelgesteuerte oder fest verdrahtete Maschinen,

- nur Universal- oder auch Spezialmaschinen (Mehrzweck- oder Einzweckgeräte),

- nur ausgereifte, ausgewachsene Rechner oder auch Versuchsmodelle, 
- nur voll und dauerhaft funktionstüchtige oder auch bloß vorübergehend oder lediglich teilweise betriebsfähige Automaten,

- nur öffentlich zugängliche, zivile oder auch geheime militärische Vorhaben?

Die Frage nach dem Erstling lässt sich nur bedingt beantworten, sie ist teilweise dem Ermessen anheimgestellt (vgl. Kasten). Die Ergebnisse sind, wie in der Geschichtsschreibung gang und gäbe, häufig patriotisch beeinflusst.

\section{Wer war zuerst?}

Es gibt viele digitale Erstrechner. Die Relaisrechner sind (elektro)mechanisch, die Röhrenrechner elektronisch. Auf die Röhrenrechner folgten die (elektronischen) Transistorrechner. Heute werden alle diese Maschinen üblicherweise mit Computer bezeichnet. Beispiele:

- erster (fest programmierter) arbeitsfähiger spezieller Relaisrechner mit Fernzugriff: Complex computer (1939),

- erster arbeitsfähiger programmgesteuerter binärer Relaisrechner mit Gleitpunktrechnung: Zuse Z3 (1941),

- erster (fest programmierter) binärer spezieller Röhrenrechner: ABC (1942),

- erster programmierbarer amerikanischer Relaisrechner: Bell-Rechner 2 (1943),

- erster großer, praktisch nutzbarer spezieller Röhrenrechner: Colossus 1 (1943),

- erster serienmäßig gefertigter spezieller Röhrenrechner: Colossus 2 (1944),

- erster arbeitsfähiger universeller Relaisrechner der USA: Harvard mark 1/IBM ASCC (1943/44),

- erster käuflicher programmgesteuerter Relaisrechner: Zuse Z4 (1945),

- erster arbeitsfähiger universeller Röhrenrechner: Eniac (1946),

- erster ansatzweise speicherprogrammierter Relais-Röhren-Mischrechner: IBM SSEC (1948),

- erster experimenteller speicherprogrammierter Röhrenrechner: Manchester baby (1948),

- erster praktisch nutzbarer speicherprogrammierter Röhrenrechner: Edsac 1 (1949),

- erster käuflicher speicherprogrammierter Röhrenrechner: Binac (1949),

- erster speicherprogrammierter Röhrenrechner der USA: Binac (1949),

- erster serienmäßig gefertigter käuflicher Röhrenrechner: Ferranti mark 1 (1951),

- erster serienmäßig gefertigter kaufmännischer Röhrenrechner der USA: Univac 1 (1951),

- erster in mehreren Exemplaren gefertigter wissenschaftlicher Röhrenrechner der USA: Era 1101 (ursprünglich Atlas 1, Vertrieb als Era 1101 ab 1951),

- erster Röhrenrechner mit Echtzeitbetrieb: Whirlwind (1951), 
- erster serienmäßig gefertigter wissenschaftlicher Röhrenrechner von IBM: IBM 701 (1952),

- erster massenhaft gefertigter speicherprogrammierter Röhrenrechner: IBM 650 (1953).

\subsubsection{Wettlauf um die erste speicherprogrammierte Rechenanlage}

Es ist offensichtlich, dass nicht Turings Abhandlung von 1936, sondern von Neumanns Edvac-Bericht (1945) und die Vortragsreihe der Universität von Pennsylvania in Philadelphia (1946) allgemein den Anstoß zur Herstellung speicherprogrammierter Maschinen gaben. Beim nun einsetzenden Wettlauf hatten englische Forschungsstätten, die Universitäten Manchester und Cambridge, die Nase vorn. Ihre Vorhaben waren bescheidener als die der Amerikaner. Hilfreich waren wohl auch die Erfahrungen mit dem (geheimen) Colossus, dessen Existenz 1945 in Manchester bekannt war (siehe David Anderson: Contested histories: De-mythologising the early history of modern British computing, in: Arthur Tatnall (Hg.): History of computing. Learning from the past, Springer, Berlin 2010, Seiten 58-67). Den Anstoß zu dem weltweiten Bau moderner Elektronenrechner gaben amerikanische Meisterleistungen: Eniac, Edvac, IAS-Maschine (Philadelphia und Princeton).

Ab Anfang der 1940er Jahre entstanden die ersten Digitalrechner (vgl. Tab. 1.9).

Tab. 1.9: Entwicklung der ersten digitalen Rechenautomaten 1940-1946 (Auswahl)

\begin{tabular}{|c|c|c|c|c|c|c|c|c|}
\hline Land & $1939 / 40$ & 1941 & 1942 & 1943 & 1944 & 1945 & 1946 & Bemerkungen \\
\hline USA & $\begin{array}{l}\text { Bell- } \\
\text { Rechner } 1\end{array}$ & & & & & & & $\begin{array}{l}\text { fest- } \\
\text { programmierter } \\
\text { Relaisrechner }\end{array}$ \\
\hline $\begin{array}{l}\text { Deutsch- } \\
\text { land }\end{array}$ & & $\begin{array}{l}\text { Zuse } \\
\text { Z3 }\end{array}$ & & & & & & $\begin{array}{l}\text { lochstreifen- } \\
\text { gesteuerter } \\
\text { Relaisrechner }\end{array}$ \\
\hline USA & & & $A B C$ & & & & & $\begin{array}{l}\text { fest- } \\
\text { programmierter } \\
\text { Röhrenrechner }\end{array}$ \\
\hline England & & & & Colossus 1 & & & & $\begin{array}{l}\text { stecktafel- } \\
\text { gesteuerter } \\
\text { Röhrenrechner }\end{array}$ \\
\hline USA & & & & & $\begin{array}{l}\text { Harvard } \\
\text { mark } 1\end{array}$ & & & $\begin{array}{l}\text { lochstreifen- } \\
\text { gesteuerter } \\
\text { Relaisrechner }\end{array}$ \\
\hline
\end{tabular}


Deutsch-

land

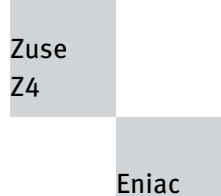

lochstreifengesteuerter Relaisrechner stecktafelgesteuerter Röhrenrechner

(c) Bruderer Informatik, CH-9401 Rorschach 2020

\section{Anmerkungen}

Der erste Bell-Rechner war Ende 1939 fertig und wurde Anfang 1940 in Betrieb genommen. In dieser Übersicht fehlen weitere Bell-Rechner (2-5 A, 1943-1946). Harvard mark 1 war bereits 1943 vollendet, kam aber erst 1944 nach Cambridge. ABC ist ein Kürzel für Atanasoff-Berry-Computer. In der Nachkriegszeit nahm die Anzahl der Computer deutlich zu.

Nach dem Krieg beschleunigte sich die Entwicklung (vgl. Tab. 1.10).

Tab. 1.10: Entwicklung der ersten digitalen Rechenautomaten 1947-1953 (Auswahl, Teil 1)

\begin{tabular}{|c|c|c|c|c|c|c|c|c|}
\hline \multicolumn{9}{|c|}{ Frühe digitale Relais- und Röhrenrechner: 1947-1953 (Auswahl, Teil 1) } \\
\hline Land & 1947 & 1948 & 1949 & 1950 & 1951 & 1952 & 1953 & Bemerkungen \\
\hline England & ARC 2 & & & & & & & $\begin{array}{l}\text { lochstreifen- } \\
\text { gesteuerter } \\
\text { Relaisrechner }\end{array}$ \\
\hline USA & & IBM SSEC & & & & & & $\begin{array}{l}\text { lochstreifen- } \\
\text { gesteuerter } \\
\text { Mischrechner }\end{array}$ \\
\hline England & & SSEM & & & & & & $\begin{array}{l}\text { speicher- } \\
\text { programmierter } \\
\text { Röhrenrechner }\end{array}$ \\
\hline USA & & & Binac & & & & & $\begin{array}{l}\text { speicher- } \\
\text { programmierter } \\
\text { Röhrenrechner }\end{array}$ \\
\hline Australien & & & Csirac & & & & & $\begin{array}{l}\text { speicher- } \\
\text { programmierter } \\
\text { Röhrenrechner }\end{array}$ \\
\hline England & & & Edsac & & & & & $\begin{array}{l}\text { speicher- } \\
\text { programmierter } \\
\text { Röhrenrechner }\end{array}$ \\
\hline Schweden & & & & Bark & & & & $\begin{array}{l}\text { stecktafel- } \\
\text { gesteuerter } \\
\text { Relaisrechner }\end{array}$ \\
\hline
\end{tabular}




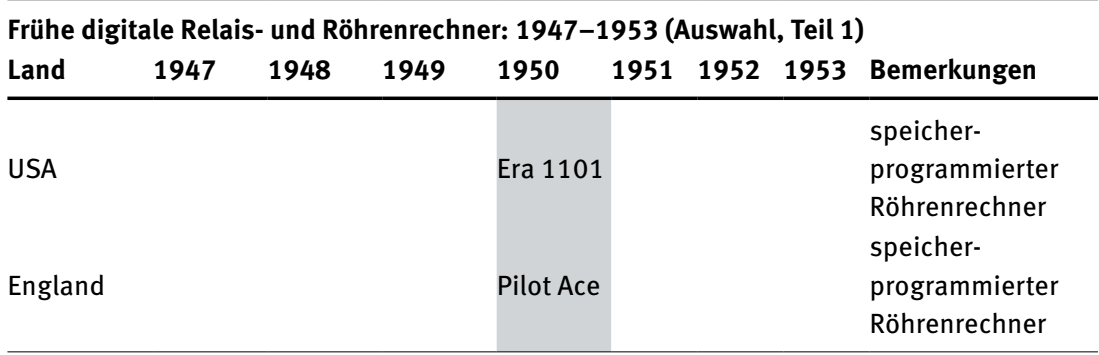

(c) Bruderer Informatik, CH-9401 Rorschach 2020

In den 1950er Jahren gaben die USA den Ton an (vgl. Tab. 1.11).

Tab. 1.11: Entwicklung der ersten digitalen Rechenautomaten 1947-1953 (Auswahl, Teil 2)

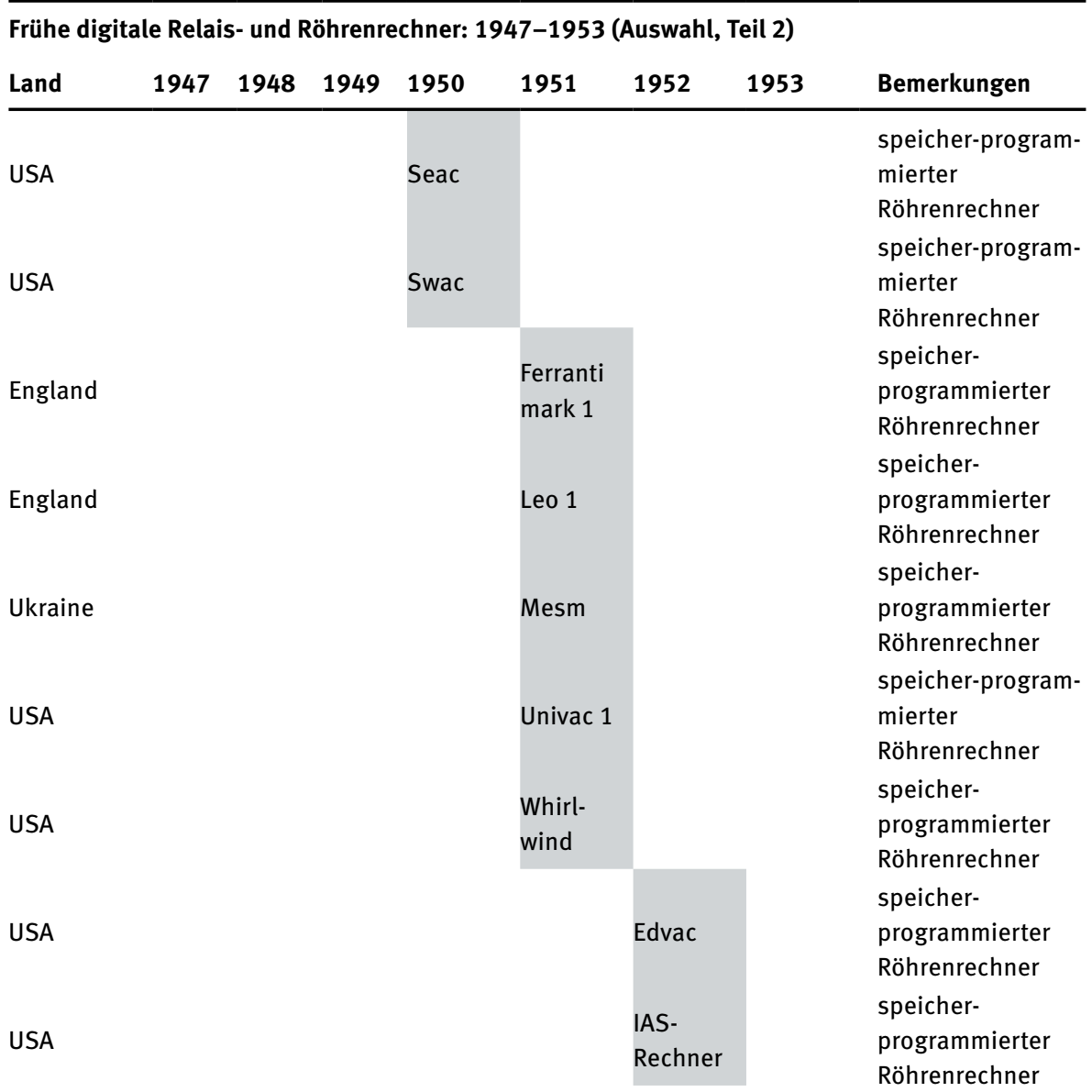




\begin{tabular}{|c|c|c|c|c|c|c|c|c|}
\hline Land & 1947 & 1948 & 1949 & 1950 & 1951 & 1952 & 1953 & Bemerkungen \\
\hline USA & & & & & & IBM 701 & & $\begin{array}{l}\text { speicher- } \\
\text { programmierter } \\
\text { Röhrenrechner }\end{array}$ \\
\hline USA & & & & & & & IBM 650 & $\begin{array}{l}\text { speicher- } \\
\text { programmierter } \\
\text { Röhrenrechner }\end{array}$ \\
\hline
\end{tabular}

(C) Bruderer Informatik, CH-9401 Rorschach 2020

Anmerkungen

SSEM ist das Manchester baby. IBM SSEC ist ein Mischrechner aus Relais und Röhren. In dieser Übersicht fehlen Harvard mark 2 (1947, Zwillingsmaschine), mark 3 (1950) und mark 4 (1952) sowie die Bell-Rechner 5B (1947) und 6 (1949). ARC steht für automatic relay calculator, Era für Engineering research associates.

\subsection{Welches ist der erste speicherprogrammierte Rechner?}

Die Antwort auf die Frage nach der ersten speicherprogrammierten Rechenanlage fällt meist national gefärbt aus. Das überrascht nicht, denn speicherprogrammierte Rechner gelten als Universalrechner, als moderne Computer schlechthin. Dem Hersteller der ersten speicherprogrammierten Maschine kommt daher eine besondere Bedeutung $\mathrm{zu}$, in der Technikgeschichte wie in der Werbung. In England hat man sich offenbar auf ein eigenartiges salomonisches „Doppelpaket“ mit Manchester und Cambridge geeinigt, in den USA weist man auf Maschinen aus New York und Philadelphia hin.

Britische Technikhistoriker betonen, dass das Manchester baby (Manchester, Juni 1948) die erste speicherprogrammierte Versuchsmaschine und Edsac (Cambridge, Mai 1949) der erste praktisch brauchbare speicherprogrammierte Rechner war.

Das Manchester baby (vgl. Abb. 1.3) gilt als erster echter speicherprogrammierter Rechner. Es war keine ausgereifte Maschine. Zielsetzung war angeblich in erster Linie die Erprobung der neuen Williams-Kilburn-Speicherröhre. Der „Säugling“ wurde zum Manchester mark und zum Ferranti mark 1 weiter entwickelt. Dieser wissenschaftlich ausgerichtete Digitalrechner wurde ab 1951 vertrieben.

Amerikaner bestehen hingegen darauf, dass der Mischrechner IBM SSEC (Endicott bei New York) gewisse Anweisungen in seinem Schnellspeicher speichern und ändern konnte. Mit dem lochstreifengesteuerten Zwitter IBM SSEC (Januar 1948) gab es schon vor dem Manchester baby ein speicherprogrammiertes Gerät, wenn auch nur ansatzweise. Der Großrechner hatte einen kleinen elektronischen und einen größeren Relaisspeicher. 
Allgemein wird der Vorrang den englischen Rechnern zugestanden, das ist jedoch bis heute umstritten. Randell äußert sich in seiner Einleitung zum Kapitel "Stored program electronic computers" wie folgt:

„[...] the IBM SSEC, which first worked in 1947, did have the ability to modify and then execute instructions held in its eight-word memory, but this was hardly a stored program computer in the normal sense of the phrase, being basically a tape-controlled machine in the tradition of the Harvard mark I or the Bell Laboratories model V.“ (siehe Brian Randell (Hg.): The origins of digital computers, Springer-Verlag, Berlin, Heidelberg usw., 3. Auflage 1982, Seite 379).

IBM SSEC lief erstmals 1947. Der Rechner war in der Lage, Befehle, die in seinem 8-Wort-Hauptspeicher abgelegt waren, zu verändern und dann auszuführen. Das war aber kaum ein speicherprogrammierter Digitalrechner im üblichen Sinn. Denn es handelt sich in erster Linie um eine lochstreifengesteuerte Maschine nach dem Muster des Harvard mark 1 oder des Bell-Rechners 5.

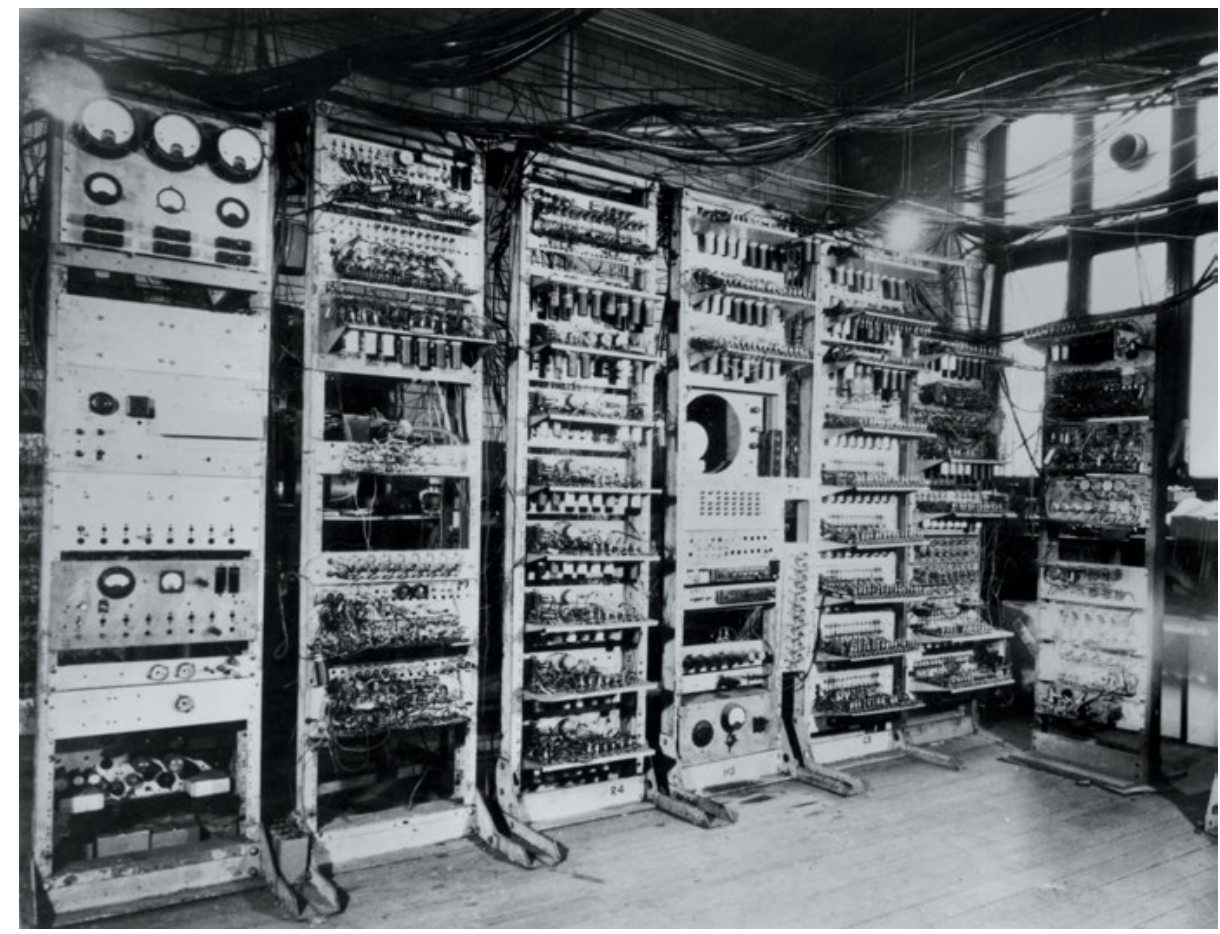

Abb. 1.3: Manchester mark 1 (1948). Diese zeitgenössische Aufnahme zeigt den (laut britischen Angaben) ersten vollelektronischen speicherprogrammierten Rechner in Betrieb. Er wurde unter der Leitung von Max Newman an der Universität Manchester gebaut, unterstützt durch einen Zuschuss der Royal society. Aufgrund des Erfolgs beauftragte die Regierung die Waffen- und Elektronikfabrik Ferranti Ltd. (Manchester) mit der Fertigung der Maschine. 1951 wurde der erste Ferranti mark im Handel angeboten (@ Science Museum, London/Science \& society picture library). 


\title{
Hinweis
}

Üblicherweise unterscheidet man zwischen dem Manchester baby (1948), dem speicherprogrammierten Erstrechner, und seiner Weiterentwicklung zum Manchester mark 1 (1949). Hier liegt also ein Widerspruch vor.

Der Zeitzeuge Goldstine, ein enger Mitarbeiter von John von Neumann, berichtet:

\begin{abstract}
„During 1947 von Neumann realized that the lack of a centralized control organ for the Eniac was not an incurable deficiency. He suggested that the whole machine could be programmed into a somewhat primitive stored program computer. He turned the task over to Adele Goldstine, who worked out such a system and passed it along to Richard Clippinger, who was then the head of the Computing Laboratory at the Ballistic Research Laboratories and is also a mathematician of note. He and his associates made certain emendations and put the final touches on the idea, and on 16 September 1948 the new system ran on the Eniac. Although it slowed down the machine's operation, it speeded up the programmer's task enormously. Indeed, the change was so profound that the old method was never used again." (siehe Herman Heine Goldstine: The computer from Pascal to von Neumann, Princeton university press, Princeton, New Jersey 1993, Seite 233).
\end{abstract}

1947 erkannte von Neumann, dass das Fehlen eines zentralen Steuerwerks für Eniac kein unbehebbarer Mangel war. Er wies darauf hin, dass sich die ganze Maschine in einen ziemlich einfachen speicherprogrammierten Rechner umwandeln lasse. Er übertrug die Aufgabe an Adele Goldstine [Goldstines Frau]. Sie entwarf eine entsprechende Lösung und leitete sie an Richard Frederick Clippinger weiter, den damaligen Vorstand des Rechenzentrums der Ballistic research laboratories. Dieser war auch ein namhafter Mathematiker. Er und seine Mitarbeiter verbesserten den Vorschlag. Am 16. September 1948 lief das neue Verfahren auf Eniac. Obwohl es den Betrieb der Maschine verlangsamte, beschleunigte es das Programmieren stark. Die Veränderung war so bedeutend, dass die alte Methode nie wieder verwendet wurde.

Eniac ist kein echter speicherprogrammierter Rechner (vgl. Kasten).

Enicac hatte eine starre Speicherprogrammierung mit Funktionstafeln

Eniac war ursprünglich (1946) eine Spezialmaschine für ballistische Berechnungen und wurde von außen über Steckverbindungen und Schrittschalter gesteuert. Auch nach der Umgestaltung blieb die Speicherprogrammierung der Maschine starr. Die Abläufe ließen sich ab 1948 manuell (extern) über Funktionstafeln einstellen. Der Elektronenrechner hatte einen mit Schaltern gesetzten (nicht veränderbaren) Nurlesespeicher (Festspeicher).

Der krampfhafte Versuch dreier Technikhistoriker, Eniac zum ersten Rechner mit Speicherprogramm zu küren, vermag nicht zu überzeugen (siehe Thomas Haigh; Mark Priestley; Crispin Rope: Eniac in action, MIT press, Cambridge, Massachusetts, London 2016).

\section{Hinweis}

Wie dem Werk von Haigh, Priestley und Rope (Seiten 164, 194 und 244) zu entnehmen ist, ist das von Goldstine genannte Datum 16. September 1948 irrtümlich. Am 12. April 1948 fand die erste Vorführung mit neuer Kodiertechnik statt. Der Nutzbetrieb begann am 28. April 1948. 


\section{Zusammenfassung}

Als erster vollwertiger speicherprogrammierter Rechenautomat gilt Edsac (Mai 1949) (vgl. Abb. 1.4- 1.5). Nachfolger war Edsac 2. Edsac wurde für kaufmännische Bedürfnisse ausgestaltet und im Handel unter der Marke Leo angeboten.

Der erste echte, speicherprogrammierte amerikanische Rechner war Binac (August 1949), eine Einzelanfertigung (Zwillingsmaschine). Seac (1950) wird als erster speicherprogrammierter US-Rechner in regelmäßigem Betrieb bezeichnet. Der erste marktfähige und in höheren Stückzahlen gefertigte amerikanische Universalrechner hieß Univac 1 (1951). IBM 701 (1952) wird als erster (echter) speicherprogrammierter IBM-Rechner betrachtet. Das Manchester baby, IBM SSEC und Eniac zählen als eingeschränkt speicherprogrammierte Rechner.

\section{Anmerkungen}

Als „Universalrechner“ werden auch Automaten mit externer Programmsteuerung wie die Zuse Z4 betrachtet. Und selbst gewisse Integrieranlagen, bei denen die Lösung von Differenzialgleichungen im Vordergrund steht, schmücken sich zur Abgrenzung von Spezialgeräten mit dem Kennzeichen „universell“. Der britische Spezialrechner Colossus (1943) war zwar programmgesteuert, aber nicht speicherprogrammiert.

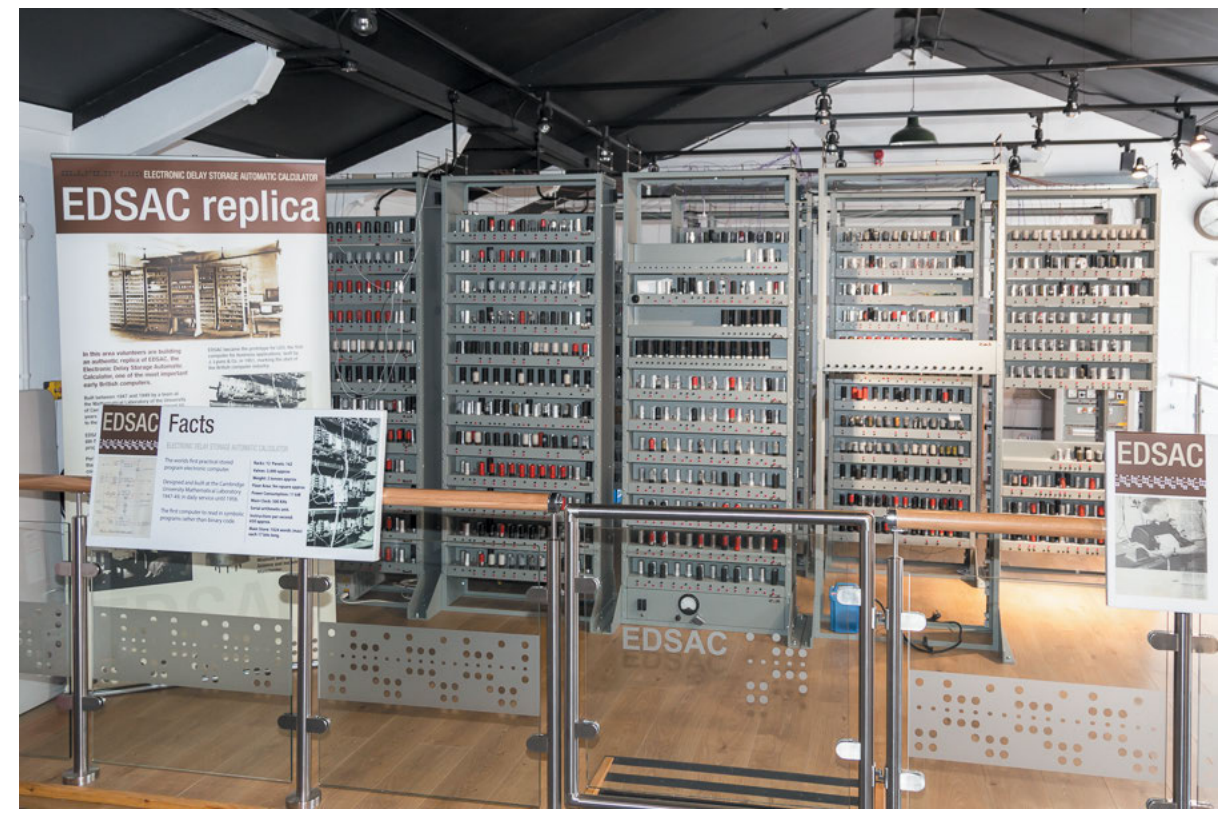

Abb. 1.4: Röhrenrechner Edsac (A). Unter der Leitung von Maurice Wilkes wurde in der Universität Cambridge der speicherprogrammierte Elektronenrechner Edsac 1 entwickelt. Er ist dank eines Nachbaus wieder auferstanden (C) The National Museum of Computing, Bletchley Park). 


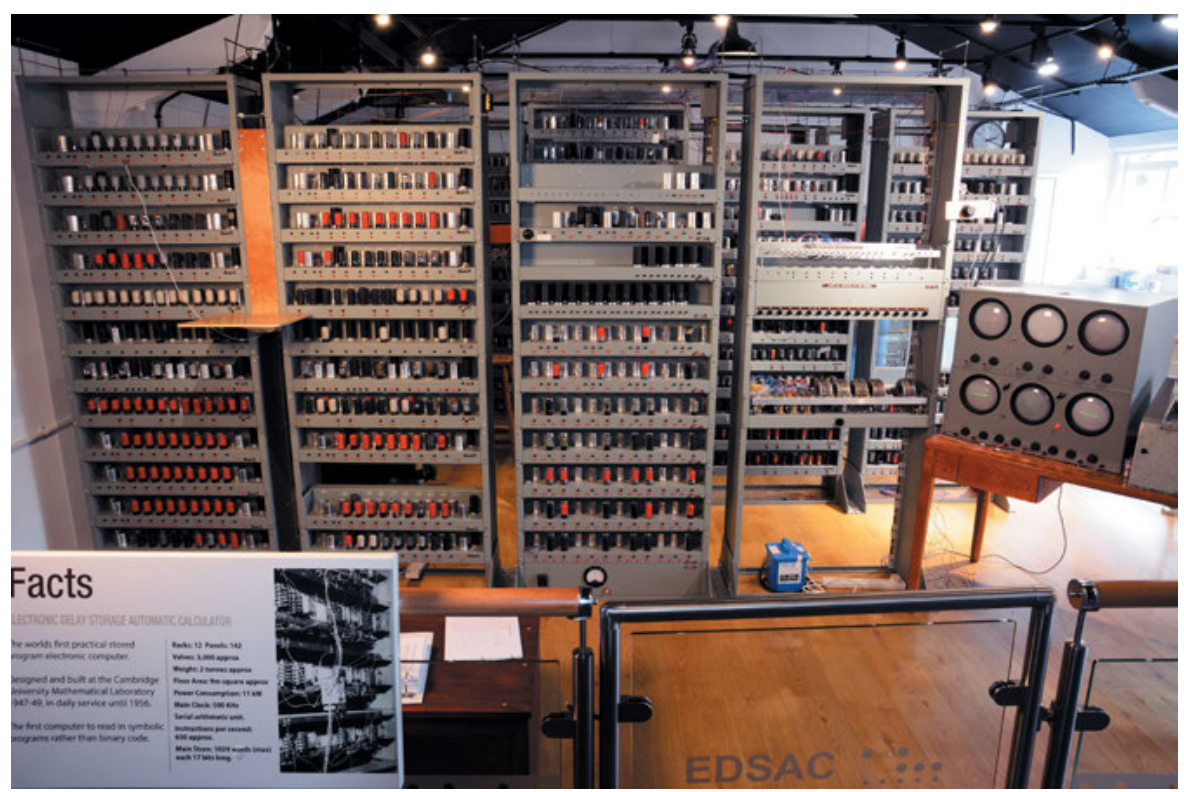

Abb. 1.5: Röhrenrechner Edsac (B). Edsac 1 gilt als erste wirklich praxistaugliche Maschine mit Speicherprogramm. Auf der Grundlage dieses Rechners entstanden die marktfähigen Bürorechner Leo (C The National Museum of Computing, Bletchley Park). Rechner mit Speicherprogramm tauchen zuerst in England und den USA auf (vgl. Tab. 1.12).

Tab. 1.12: Entstehung der Digitalrechner mit gespeichertem Programm

\begin{tabular}{lll}
\hline \multicolumn{3}{l}{ Frühe speicherprogrammierte Rechner } \\
Jahr & Rechner & Ort \\
\hline 1948 & IBM SSEC & IBM, New York \\
1948 & Manchester baby & Universität Manchester \\
1948 & Eniac & Universität von Pennsylvania in Philadelphia \\
1949 & Edsac & Universität Cambridge \\
1949 & Binac & Eckert-Mauchly, Philadelphia \\
1949 & Csirac & Csiro, Sydney \\
1950 & Pilot Ace & National physical laboratory, Teddington \\
1950 & Seac & Bureau of standards Ost, Washington, D.C. \\
1950 & Era 1101 & Engineering research associates, St. Paul \\
1950 & Mesm & Institut für Elektrotechnik, Kiew \\
\hline C Bruderer Informatik, CH-9401 & Rorschach 2020 \\
\hline
\end{tabular}




\subsection{Wer hatte wieviel Einfluss auf die Rechnerentwicklung?}

Auf dem steinigen Weg zum heutigen Computer haben unzählige Tüftler, Erfinder, Forscher und Kaufleute mitgewirkt. Beteiligt waren auch Frauen: Ada Lovelace, Grace Hopper, die Programmierinnen des Rechenriesen Eniac und die Mitarbeiterinnen im britischen Geheimdienstzentrum Bletchley Park.

Ohne die vielen grundlegenden theoretischen Arbeiten und die zeitraubende praktische Umsetzung wäre die Entwicklung undenkbar. Im Folgenden werden die Meisterwerke ausgewählter Pionierinnen und Pioniere der Frühzeit gestreift. Zu ergänzen sind die Leistungen von George Boole (boolesche Algebra), Claude Shannon (Informationstheorie) und vieler anderer. Erwähnt werden Vorreiter aus Deutschland, England, Frankreich, Österreich, Schweiz, Spanien, Ukraine, Russland, USA.

Europäische Forscher besuchten meist US-amerikanische Einrichtungen, etwa in Princeton, Cambridge (Massachusetts) und Philadelphia, sie hielten sich vergleichsweise selten in England auf.

\subsubsection{Institute for advanced study, ein Besuchermagnet}

Das Institute for advanced study in Princeton, wo John von Neumann lehrte, übte eine große Anziehungskraft aus. Es war ein Mekka für künftige Rechnerbauer.

Goldstine erwähnt in seinem Buch zur Informatikgeschichte (siehe Herman Goldstine: The computer from Pascal to von Neumann, Princeton university press, Princeton, New Jersey 1993, Seiten 217, 247, 249-250, 292, 306, 349-350, 353, 355) unzählige europäische „Wallfahrer“, die mit dem Rechnerbau in Beziehung stehen. Sie weilten vorwiegend in Princeton (Institute for advanced study, ferner Radio Corporation of America), aber auch in Cambridge, Massachusetts (Harvard-Universität, MIT), und in Philadelphia (Moore school). Die Jahrzahl gibt (soweit verfügbar) den Beginn des Aufenthalts wieder:

- Deutschland: Heinz Billing,

- England: Andrew Booth (1946), Kathleen Booth (1946), Leslie Comrie (1945), Douglas Hartree (1945), Max Newman (1946), David Rees (1946), Alan Turing (1936), Maurice Wilkes (1946), John Womerlsey (1945),

- Frankreich: Louis Couffignal (1946),

- Schweden: Stig Ekelöf (1946), Carl Erik Fröberg (1947), Göran Kjellberg (1947), Gösta Neovius (1947), Erik Stemme,

- Schweiz: Hans Mähly, Ambros Speiser (1948).

Julian Bigelow, Chefingenieur der Princetonmaschine, zählt für die Zeit des Baus der Princetonmaschine u.a. auf: Andrew Booth, Kathleen Booth (beide Birkbeck college, London), Ambros Speiser (ETH Zürich), Adriaan van Wijngaarden (Mathematisch centrum, Amsterdam), Maurice Wilkes (Universität Cambridge) (siehe Julian Bigelow: 
Computer development at the Institute for advanced study, in: Nicholas Constantine Metropolis; Jack Howlett; Gian-Carlo Rota (Hg.): A history of computing in the twentieth century, Academic press, New York, London usw. 1980, Seite 310).

Robert Piloty (Technische Hochschule München) besuchte vom Mai bis Oktober 1948 die Sommerschule des Massachusetts Institute of Technology. Dabei sah er auch die (später geheime) Großrechenanlage Whirlwind, deren Entwicklung erst begonnen hatte. Er konnte zudem den Von-Neumann-Bericht beschaffen, der die Grundlage für die Anfertigung der programmgesteuerten elektronischen Rechenanlage München (Perm) bildete (siehe Hartmut Petzold: Rechnende Maschinen, VDI-Verlag, Düsseldorf 1985, Seite 389).

Marcel Linsman und William Pouliart aus Belgien waren an der Fertigung von Harvard mark 3 beteiligt (siehe Marie d'Udekem-Gevers: A little-known chapter in the history of computing in Belgium: The machine mathématique IRSIA-FNRS, in: Kai Kimppa; Diane Whitehouse; Tiina Kuusela; Jackie Phahlamohlaka (Hg.): ICT and society, Springer, Heidelberg, New York usw. 2014, Seite 147).

„In passing it should be said that, despite the relatively late completion of the Princeton project, there is little doubt that John von Neumann himself was the most influential of all the early computer pioneers." (siehe Simon Lavington: Early British computers, Manchester university press, Manchester 1980, Seite 25).

Nebenbei soll bemerkt werden, dass John von Neumann gewiss der einflussreichste aller frühen Computerpioniere war, obwohl die Princetonmaschine vergleichsweise spät fertig gestellt wurde.

Mächtige analoge Integrieranlagen erleichterten das Rechnen (vgl. Abb. 1.6) 


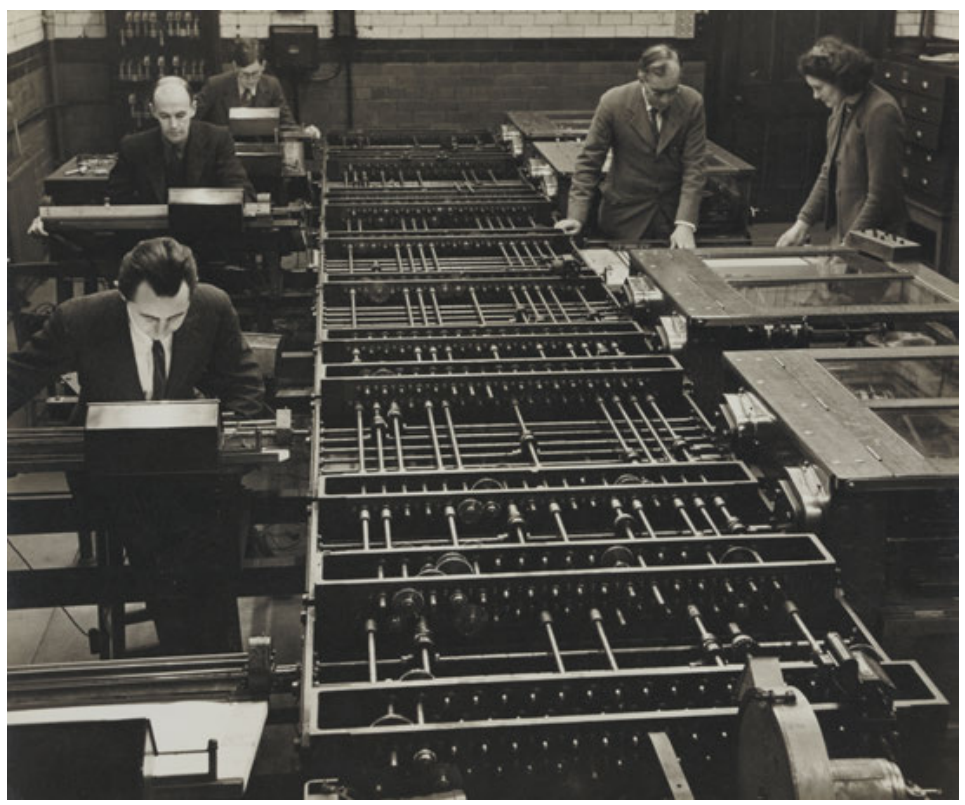

Abb. 1.6: Integrieranlage aus Manchester (1934/35). Vannevar Bushs großer Analogrechner (MIT, Cambridge, 1930/31) regte den britischen Pionier Douglas Hartree zum Nachbau an (C The British Council/Universtität Manchester).

Der riesige Röhrenrechner Eniac (vgl. Abb.1.7-1.8) hat weltweit eine große Beachtung gefunden.

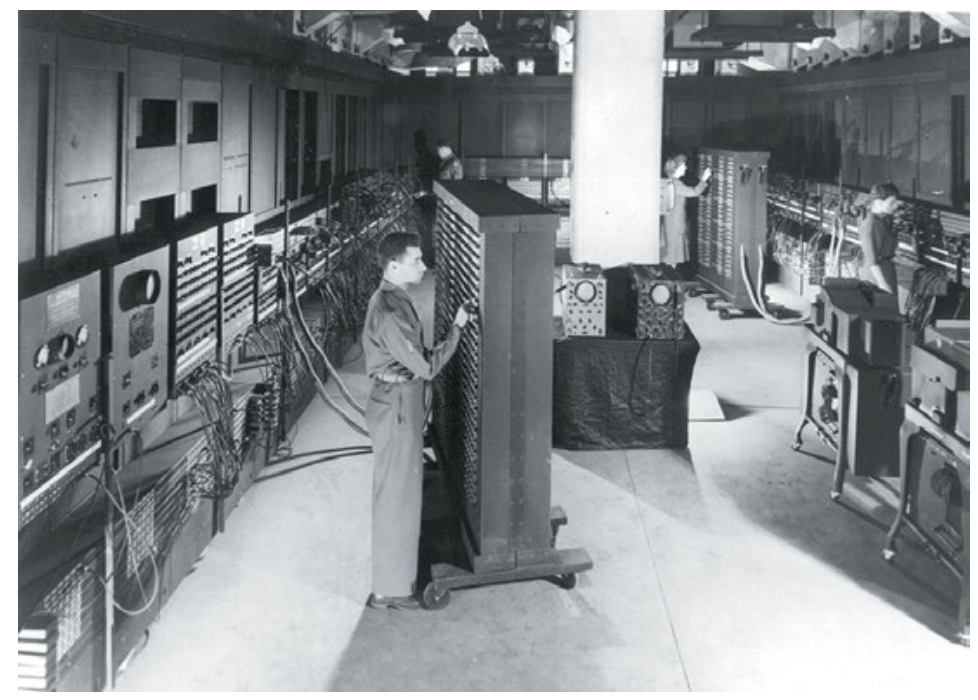

Abb. 1.7: Eniac (1). Der an der Universität von Pennsylvania in Philadelphia gebaute Röhrenrechner wurde über Steckkabel programmiert (@ United States Army). 


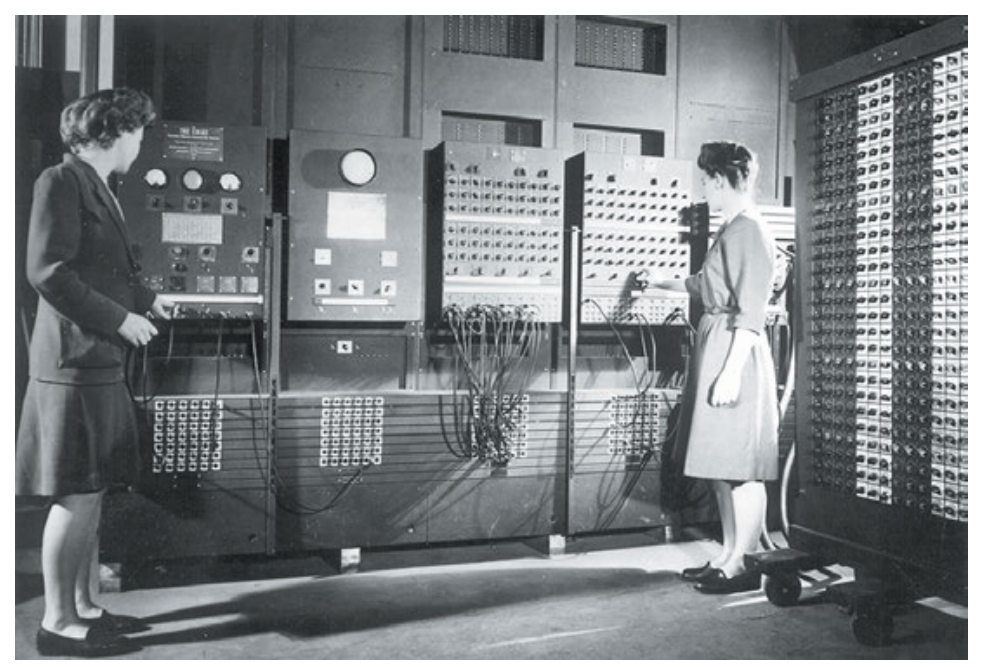

Abb. 1.8: Eniac (2). Auf dieser Aufnahme sehen Sie zwei Programmiererinnen vor dem Riesenrechner (um 1946) (C) United States Army).

\subsubsection{Wer war tonangebend?}

Es folgen in alfabetischer Reihenfolge einige ausgewählte Hauptdarsteller.

Howard Aiken

Howard Aiken gehört zu den bekanntesten frühen Informatikpionieren. Sein Vorbild war Charles Babbage. Das programmgesteuerte elektromechanische Gerät Harvard mark 1/IBM ASCC (1944) entstand gemeinsam mit IBM. Anschließend trennten sich die Wege, denn Aiken hatte die Verdienste von IBM missachtet. Es wurden drei Nachfolgemaschinen hergestellt. Die Relaisrechner hatten den Ruf, zuverlässig zu sein, waren technisch aber bald veraltet. Bei allen vier Harvard-Maschinen bestand eine Trennung von Programm- und Datenspeicher. Eine Mitarbeiterin des Rechenzentrums war Grace Hopper, die sich (später) mit der Entwicklung von „Übersetzern“ (Compiler) und Programmiersprachen einen Namen gemacht hat. Die Harvard-Universität in Cambridge veranstaltete schon in den 1940er Jahren Tagungen zur Rechentechnik. Zu nennen ist auch die Aiken-Verschlüsselung.

\section{John Atanasoff}

Bis zum Patentstreit Honeywell gegen Sperry Rand wusste man wenig von John Atanasoff und dem Atanasoff-Berry-Computer (Iowa State College, Ames, 1942). Seine wegen des zweiten Weltkriegs abgebrochene Arbeit hatte laut dem bis heute umstrittenen, 1973 verkündeten Bundesgerichtsurteil einen so starken Einfluss auf den Bau der Röhrenmaschine Eniac, dass das Patent von Mauchly und Eckert aufgehoben wurde. Mauchly hatte nach mehreren Besuchen bei Atanasoff offenbar ohne Erlaub- 
nis Erkenntnisse genutzt, die bei der Konstruktion des Elektronenrechners ABC gewonnen worden waren.

\section{Charles Babbage}

Der an der englischen Universität Cambridge tätige Charles Babbage war ein berühmter Mathematiker. Seine Differenzenmaschine blieb zwar unvollendet, hatte aber mehrere Nachbauten zur Folge, beispielsweise in Schweden. Die von Ada Lovelace beschriebene, 1834 begonnene analytische Maschine war ihrer Zeit um volle 100 Jahre voraus. Lovelace hatte einen in einer Genfer Zeitschrift erschienenen Aufsatz von Luigi Federico Menabrea ins Englische übersetzt und stark erweitert. Babbages programmgesteuerter Digitalrechner wurde nie gebaut und geriet in Vergessenheit. Dem Erfinder blieb eine Anerkennung für seine zukunftsträchtige Arbeit versagt. Heute gilt die programmgesteuerte analytische Maschine als bedeutende Vorläuferin unserer Elektronenrechner.

\section{Vannevar Bush}

1930/31 war Vannevar Bushs erste mechanische Integrieranlage fertig gestellt, 1942 folgte die zweite, eine elektromechanische Maschine. Der Rockefeller differential analyzer (RDA) wurde im zweiten Weltkrieg für das Manhattan-Projekt (Atombombe) sowie für die Radar- und Ballistikforschung verwendet. Das große analoge Vielzweckgerät des Massachusetts Institute of Technology (Cambridge) wurde vielerorts nachgebaut, u.a. in England (Manchester, Cambridge), Norwegen (Oslo) und auch in Philadelphia. Elektronische Analogrechner waren bis $\mathrm{zu}$ ihrer Verdrängung durch digitale programmgesteuerte Rechenautomaten weit verbreitet. 1945 schlug Bush das Memexsystem (webähnliches Verweissystem auf Mikrofilm) vor.

\section{Presper Eckert}

Der im zweiten Weltkrieg an der Universität von Pennsylvania in Philadelphia gebaute Röhrenrechner Eniac (1946) verblüffte die Fachwelt durch seine riesigen Ausmaße. Die Programmierung über Steckkabel und Schalter war hingegen schwerfällig. Nach einer Auseinandersetzung mit von Neumann verließen John Mauchly und Presper Eckert die Moore school of electrical engineering und gründeten ein eigenes Unternehmen. Ihre Erzeugnisse wurden schließlich als Univac-Rechner weltweit vertrieben. Eckert verbesserte die aus der Radartechnik stammenden, mit Quecksilber gefüllten Elektronenröhren. Sie waren wie die Williamsröhren häufig verwendete Speicherbausteine.

\section{Thomas Flowers}

Der 1943 von Thomas Flowers entwickelte britische Elektronenrechner Colossus, mit dem die Funksprüche der deutschen Lorenz-Schlüsselmaschine (SZ42) geknackt wurden, war bis 1975 hoch geheim. Die an der Londoner Post office research station gefertigte stecktafelgesteuerte Röhrenmaschine blieb (angeblich) lange Zeit unbeachtet. Max Newman hat jedoch laut David Anderson den Vorstand der Fakultät für Elektrotechnik der Universität Manchester (Willis Jackson) über die Existenz des 
Colossus ins Bild gesetzt und ihm in Bletchley Park im Sommer 1945 mehrere Maschinen gezeigt (siehe David Anderson: Contested histories: De-mythologising the early history of modern British computing, in: Arthur Tatnall (Hg.): History of computing. Learning from the past, Springer, Berlin 2010, Seiten 58-67).

\section{Douglas Hartree}

$\mathrm{Zu}$ den besten Kennern der analogen und digitalen Rechnerwelt gehörte Douglas Hartree. 1933/34 baute er mit Arthur Porter an der Universität Manchester die erste britische Integrieranlage (aus Meccano-Bauteilen). Sein Vorbild war der Analogrechner von Vannevar Bush vom MIT, Cambridge (1930/31). Hartree sorgte im Auftrag der britischen Regierung für die wissenschaftliche Verbindung zwischen den USA und Großbritannien. Schon 1946 verbreitete er die Kunde über den im zweiten Weltkrieg entwickelten Mammutrechner Eniac. Wahrscheinlich hatte er Maurice Wilkes (Universität Cambridge) und David Rees (Universität Manchester) eine Einladung zum Besuch der Lehrveranstaltung an der Moore school in Philadelphia vermittelt, wo Hartree auch einen Vortrag hielt. Er hatte Wilkes sein persönliches Exemplar des VonNeumann-Berichts (Edvac-Bericht) ausgeliehen.

\section{Curt Herzstark}

Die winzige mechanische Taschenrechenmaschine von Curt Herzstark, die Curta, die von 1948 bis 1971 in Liechtenstein in Serie gebaut wurde, gilt immer noch als technisches Wunderwerk. Die Universität Birmingham hatte 1953 einen Matrixrechner mit 12 Curtas konstruiert. Die aufkeimende Elektronik löste die Mechanik allerdings rasch $\mathrm{ab}$.

\section{Helmut Hoelzer}

Helmut Hoelzer gilt in Deutschland als Erbauer des ersten elektronischen Analogrechners (1941). Im Ausland weiß man aber wenig über seine Errungenschaften.

\section{Herman Hollerith}

Die Lochkartenmaschinen von Herman Hollerith bestanden ihre erste große Bewährungsprobe bei der 11. amerikanischen Volkszählung von 1890. Ein Mitbewerber war James Powers. IBM und Remington Rand teilten sich später den Markt auf. Die Lochkartenanlagen waren weltweit in hohen Stückzahlen jahrzehntelang lang in Gebrauch.

\section{Grace Hopper}

Grace Hopper arbeitete mit dem Relaisrechner Harvard mark 1/IBM ASCC und war bei Remington Rand tätig. Sie wird oft als Erfinderin des Übersetzers (Compiler) genannt, was aber wohl unzutreffend ist. Ihr Name ist verbunden mit der Schaffung der Programmiersprache Cobol.

\section{Joseph-Marie Jacquard}

Die Steuerung von Webstühlen durch Lochkarten und Lochstreifen hat die Rechentechnik nachhaltig geprägt. Joseph-Marie Jacquard hatte allerdings mehrere (fran- 
zösische) Vorläufer: Basile Bouchon, Jean-Baptiste Falcon und Jacques Vaucanson. Dank der Lochbänder (aneinandergebundene Lochkarten) ließen sich die Abläufe automatisieren.

Sergei Lebedew (auch Sergej Lebedjew und Sergei Lebedev)

Sergei Lebedew ist der Vater der sowjetischen Informatik. Er stellte u.a. die beiden Röhrenmaschinen Mesm (erster speicherprogrammierter Rechner Kontinentaleuropas) und Besm her und soll unabhängig auf den Gedanken der Speicherprogrammierung gekommen sein.

\section{Gottfried Wilhelm Leibniz}

Gottfried Wilhelm Leibniz führte seine erste mechanische Vierspeziesrechenmaschine (Gerät für alle vier Grundrechenarten) 1673 in London vor. Nach dem Sprossenrad erfand er auch die Staffelwalze. Mit diesem Schaltelement waren ab etwa 1850 unzählige, bis in die 1970er Jahre z.T. in hohen Stückzahlen gefertigte Rechenmaschinen ausgestattet. Mechanische und elektronische Geräte arbeiteten lange Zeit dezimal. Leibniz ist einer der Väter des Dualsystems. Valtat, Couffignal und Zuse hatten es für Rechenmaschinen eingesetzt.

\section{Ada Lovelace (Ada Augusta King)}

Ada Lovelace hat sich mit der Beschreibung der analytischen Rechenmaschine von Charles Babbage verdient gemacht. Sie soll auch Anweisungen zur Berechnung von Bernoullizahlen verfasst haben. Urheber des Programms ist aufgrund von Archivdokumenten jedoch Charles Babbage. Zu ihren Ehren wurde eine Programmiersprache auf den Namen Ada getauft.

\section{John Mauchly}

Der im zweiten Weltkrieg an der Universität von Pennsylvania in Philadelphia gebaute Röhrenrechner Eniac (1946) verblüffte die Fachwelt durch seine riesigen Ausmaße. Die Programmierung über Steckkabel und Schalter war hingegen schwerfällig. Nach einer Auseinandersetzung mit von Neumann verließen John Mauchly und Presper Eckert die Moore school of electrical engineering und gründeten ein eigenes Unternehmen. Ihre Erzeugnisse wurden schließlich als Univac-Rechner weltweit vertrieben.

\section{John Napier}

Die neperschen Rechenstäbchen (Edinburgh, 1617), welche die Multiplikation und die Division (sowie das Ziehen der Quadrat- und Kubikwurzel) erleichtern sollen, wurden in unterschiedlichen Formen (z.B. drehbare Walzen) in Rechenhilfsmitteln von Grillet (Vierspeziesgerät), Hahn (Rechentrommel), Kircher (mathematischer Schrein) (vgl. Abb. 1.9), Leupold (Rechentrommel), Morland (Multiplizier- und Dividiergerät), Petit (Rechentrommel), Schickard (Rechenuhr), Schott (Rechenkasten) u.a. verwendet. Genaille und Lucas boten noch Ende des 19. Jahrhunderts Rechenstäbchen an. Neben den Rechenstäbchen (vgl. Abb. 1.10) hatte Napiers noch ein zweites Rechenhilfsmittel 
hinterlassen, das Promptuarium (vgl. Abb. 1.11). Es geriet offenbar schnell in Vergessenheit. Die Rechenstäbchen waren weit verbreitet.

John Napier und Jost Bürgi haben unabhängig voneinander die Logarithmen entdeckt. Sie bildeten die Voraussetzung für die beliebten Rechenschieber und stellen einen bedeutenden Markstein in der Geschichte der Mathematik dar. Wegen Bürgis Geheimniskrämerei war Napiers Einfluss viel größer.

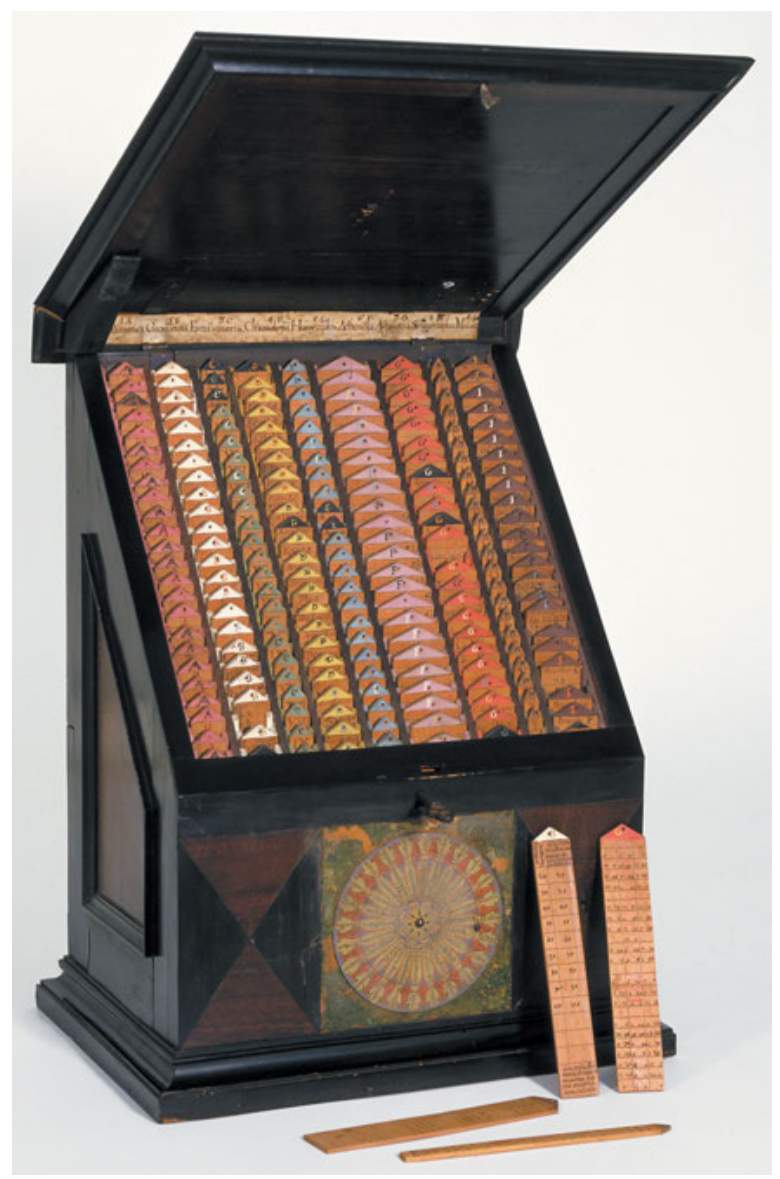

Abb. 1.9: Kirchers mathematischer Schrein. Das tragbare, durch einen Deckel verschließbare Kästchen enthält neun nebeneinander angeordnete senkrechte Fächer. Sie sind jeweils einem Thema gewidmet (z.B. Arithmetik, Geometrie, Astronomie, Astrologie, Zeitrechnung, Sonnenuhren). In jedem Fach befinden sich 24 flache Holzstäbe unterschiedlicher Länge. Auf beiden Seiten sind sie mit Zahlen und Buchstaben beschriftet. Erfinder des Lehrmittels ist der deutsche Universalgelehrte Athanasius Kircher. Sein Schüler Kaspar Schott hat den mathematischen Schrein, das Organum mathematicum, 1688 beschrieben (৫ Museo Galileo, Florenz). 


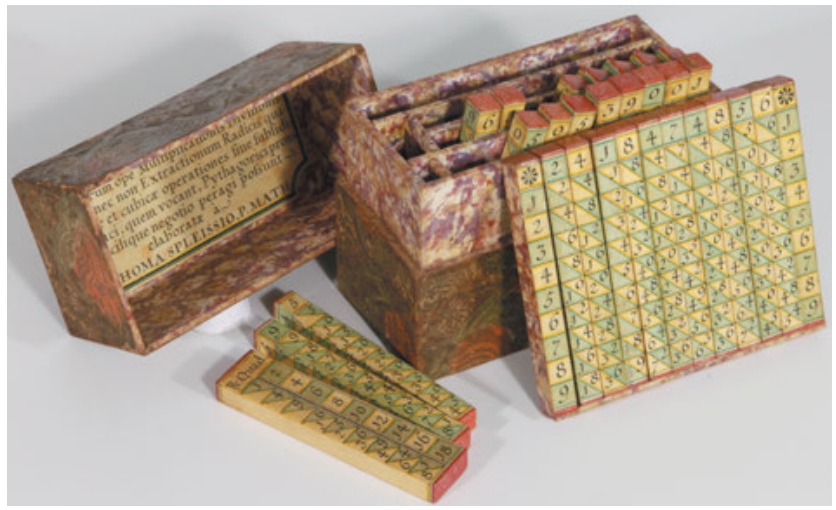

Abb. 1.10: Nepersche Rechenstäbchen. Das vom Schotten John Napier geschaffene digitale Rechenhilfsmittel erleichterte das Vervielfachen und Teilen von Zahlenwerten (C) ETH-Bibliothek Zürich, Sammlung Sternwarte).

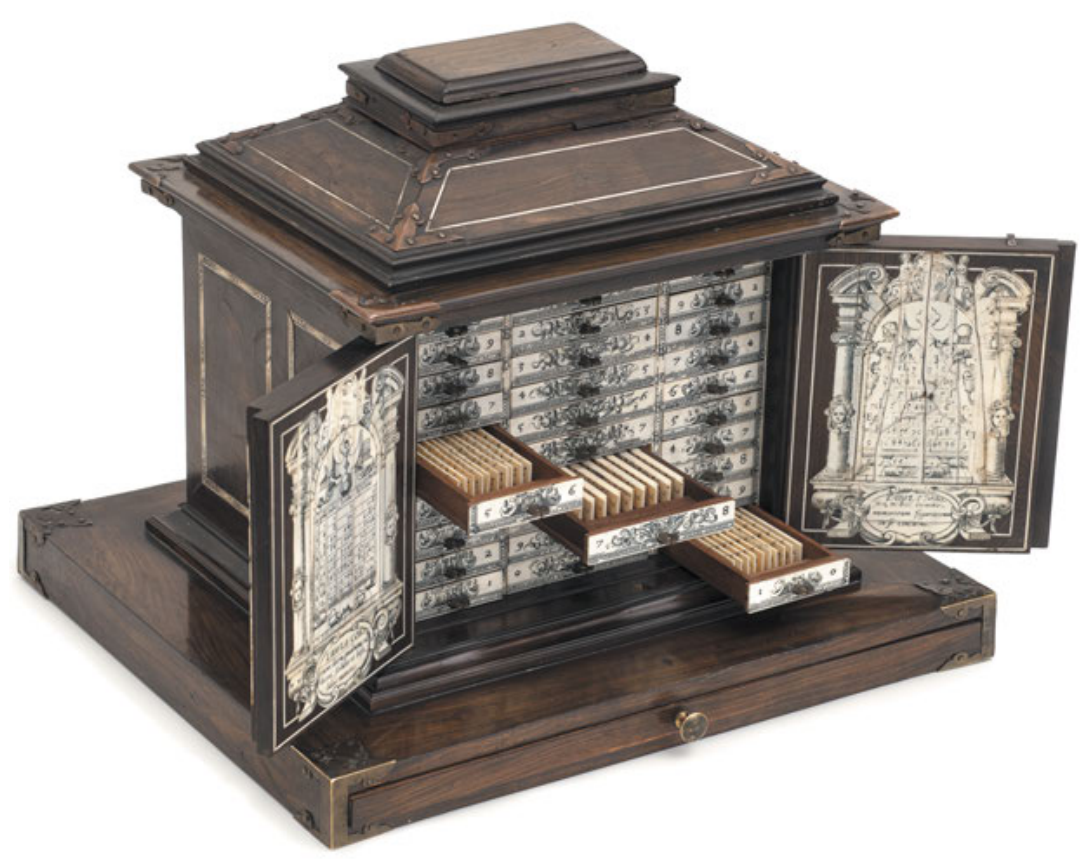

Abb. 1.11: Napiers Rechenschrank. Wer dieses prachtvolle Rechengerät hergestellt hat, ist unbekannt. Erst nach langer Zeit fand man heraus, dass es sich um ein Promptuarium handelt. Die Aufnahme stellt das weltweit wohl schönste überlebende Original dar (C) Museo arqueológico nacional, Madrid). Max Newman

Max Newman hatte an der Universität Cambridge durch eine Vorlesung Alan Turing zu der wegweisenden Arbeit über die Turingmaschine (1936) angeregt und ihre Ver- 
öffentlichung befürwortet. Newman unterstützte überdies Turings Studienaufenthalt bei Alonzo Church in Princeton. Im britischen Geheimdienstzentrum Bletchley Park hatte Newman die Vorgaben für die teils elektromechanische, teils elektronische Schlüsselbrechmaschine Heath Robinson erarbeitet. Die Nachfolgemaschine, der Elektronenrechner Colossus, war hingegen ausschließlich das Werk von Thomas Flowers. Nach dem Krieg wechselte er an die Universität Manchester und schlug den Bau eines Elektronenrechners vor. 1948 kam in Manchester der erste speicherprogrammierte (Versuchs-)Rechner Europas zur Welt.

\section{William Oughtred}

Die Erfindung des Rechenstabs und der Rechenscheibe (1622) wird William Oughtred zugeschrieben. Die analogen Rechenschieber wurden jahrhundertelang in großer Zahl verwendet.

\section{Blaise Pascal}

Die in zahlreichen Exemplaren gefertigte Pascaline (Paris, 1642) (vgl. Abb. 1.12-1.13), eine Zweispeziesmaschine, war wohl die bekannteste der frühen mechanischen Rechenmaschinen. Bis zur Wiederentdeckung der schickardschen Rechenuhr galt Blaise Pascal als (erster) Erfinder der mechanischen Rechenmaschine. Die indirekte Subtraktion mit Ergänzungszahlen wurde auch in späteren Geräten angewandt, etwa der Curta.

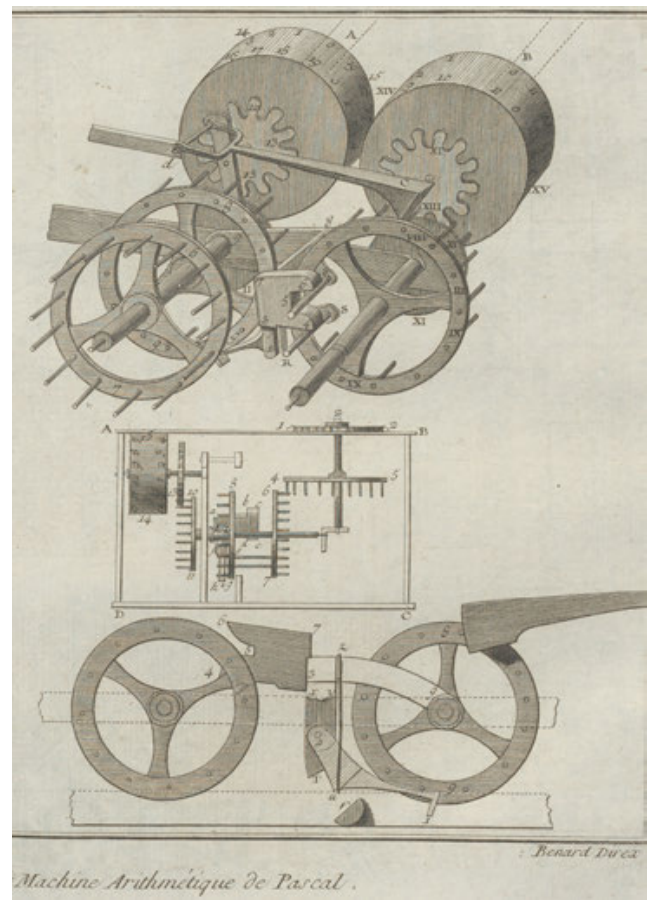

Abb. 1.12: Pascaline (1). Diese Zeichnung gibt einen Einblick in die Arbeitsweise des Addierer-Subtrahierers (aus: Denis Diderot; M. d'Alembert: Encyclopédie, ou dictionnaire raisonné des sciences, des arts et des métiers, Pellet, Genf 1778) (Quelle: ETH-Bibliothek Zürich, Alte und seltene Drucke). 


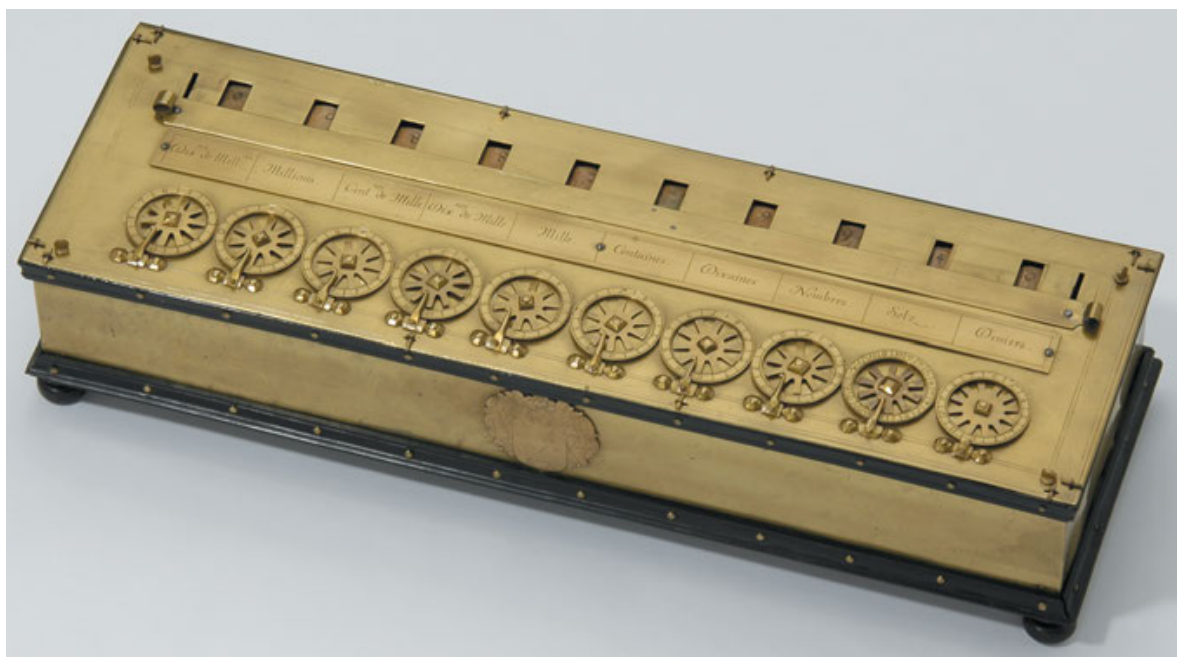

Abb. 1.13: Pascaline (2). Blaise Pascal hat rund 50 Zweispeziesmaschinen (Additions- und Subtraktionsmaschinen) hergestellt. Davon sind mehrere Originale erhalten. Dieses um 1650 gefertigte Exemplar hat ein Gehäuse aus Messingblech, eine hölzerne Bodenplatte mit gedrechselten Füßen und zwei umlaufende, ebenfalls aus braunem Holz bestehende Zierfriesen. Das Einstellwerk (unten) und das Ergebniswerk (oben) weisen je zehn Stellen auf. Die Zahlen werden mit einem Griffel eingegeben, indem man die speichenkranzförmigen Einstellräder im Uhrzeigersinn bis zum Anschlag dreht. Die Ergebnisse erscheinen in den Ablesefenstern. Für die Subtraktion werden Ergänzungszahlen verwendet. Die Pascaline zeichnet sich durch einen automatischen Zehnerübertrag aus (৫) Mathematisch-physikalischer Salon, Dresden).

\section{Heinz Rutishauser}

Heinz Rutishauser gilt als Schöpfer der automatischen Programmierung. Er erkannte als erster, dass man die Rechenmaschine selbst für das (beschwerliche) Programmieren nutzen kann. Konrad Zuse und Howard Aiken hatten für diesen Zweck noch besondere Planfertigungsgeräte vorgesehen. Rutishauser war einer der führenden Mitbegründer der maschinenunabhängigen Programmiersprache Algol, die viele Nachkommen (z.B. Pascal) hatte. Nun war es möglich, Programme auszutauschen.

\section{Wilhelm Schickard}

Die erste mechanische Rechenmaschine, ein Werk von Wilhelm Schickard (Tübingen, 1623), ist nicht überliefert. Sie hat daher keinen nennenswerten Nachhall gefunden. Unterlagen dazu tauchten erst 1957 auf, so dass sie sich rekonstruieren ließ. Die Multiplikation wird mit drehbaren Zylindern vollzogen. In vielen Museen sind Nachbauten ausgestellt.

\section{Jean-Baptiste Schwilgué}

Die 1842 vollende astronomische Uhr des Straßburger Münsters wartet mit einem einzigartigen Kirchenrechner auf. Jean-Baptiste Schwilgués Meisterwerk läuft heute 
noch. Seine 1844 patentierte Tastenaddiermaschine kam erst vor kurzem zum Vorschein, sein „Prozessrechner“ aus den 1830er Jahren wurde erst Ende 2014 aufgespürt.

\section{George Stibitz}

Der elektromechanische Complex computer von George Stibitz (Bell Labs, New York, 1939) hatte fünf Nachfolger. Der Spezialrechner hat die weitere Entwicklung aber kaum nachhaltig geprägt. Zu erwähnen ist hingegen die Stibitz-Verschlüsselung. In die Geschichte eingegangen ist eine Vorführung mit einer Fernsteuerung.

\section{Charles-Xavier Thomas}

Das 1820 patentierte Arithmometer von Charles-Xavier Thomas aus Colmar war die erste und bis in die 1870er Jahre einzige Rechenmaschine in Serienfabrikation. Hergestellt wurde sie in Paris. Später kamen viele Geräte ähnlicher Bauart in den Handel. Die Ausdrücke „Arithmometer“ und „Thomasmaschine“ wurden zum Inbegriff von Staffelwalzenmaschinen und allgemein von mechanischen Rechenmaschinen.

\section{Leonardo Torres Quevedo}

Leonardo Torres Quevedo versuchte schon 1893, mit mechanischen Mitteln schwierige algebraische Gleichungen zu lösen. 1912 baute er den ersten Schachspielautomaten, den er 1914 in Paris vorstellte. Er entwarf eine automatische elektromechanische Rechenmaschine, die 1920 in Paris ausgestellt wurde, und schrieb eine wichtige Abhandlung zur Automation. Torres Quevedo war vor allem in Spanien und Frankreich ein berühmter Gelehrter. Im deutsch- und englischsprachigen Raum ist er heute weitgehend vergessen. Seine Rechengeräte waren allerdings nicht marktreif. Torres Quevedo hat die weitere Entwicklung nicht entscheidend beeinflusst. Er war der Zeit voraus, seine spanischsprachigen Veröffentlichungen sind wenig bekannt.

\section{Alan Turing}

Es ist unbestritten, dass sich Alan Turing im zweiten Weltkrieg unermessliche Verdienste erworben hat. Nach den bedeutenden Vorleistungen der polnischen Schlüsselknacker (Codebrecher) hat er mit Unterstützung von Gordon Welchman eine Bombe genannte elektromechanische Maschine für das Brechen der deutschen Enigmas entwickelt. Es ist ihm und seinen Mitarbeitenden in Bletchley Park überdies gelungen, die unverständlichen Funksprüche der Marine-Enigma zu entziffern. Zudem hat er mit grundlegenden Verfahren (z.B. Banburismus) dazu beigetragen, die Nachrichten u.a. der Lorenzmaschine zu enträtseln. Wegen der Geheimniskrämerei der britischen Regierung erfuhr die Umwelt erst mit jahrzehntelanger Verspätung von diesen herausragenden Leistungen.

Alan Turings theoretische Abhandlung zur universellen Turingmaschine (1936) fand bei ihrer Veröffentlichung hingegen ein geringes Echo. In der theoretischen Informatik hat die Turingmaschine heute zwar eine wegweisende Stellung erlangt, allerdings erst mit einer großen Verspätung. Sie ermöglicht wichtige Aussagen etwa zur Berechenbarkeit. Turings Arbeiten zur künstlichen Intelligenz genießen ebenfalls 
eine hohe Wertschätzung. Der „Nobelpreis“ der Informatik, der Turingpreis, ist nach ihm benannt.

Manche Kryptanalytiker (Codebrecher) aus Bletchley Park wurden als Professoren an britische oder amerikanische Universitäten berufen, Turing musste sich mit einem Lehrauftrag an der Universität Manchester begnügen.

Historikerstreit: Copeland versucht hartnäckig, den Einfluss von Turings berühmter Schrift „On computable numbers“ (1936) auf John von Neumann nachzuweisen. Angeführt werden u.a. Aussagen von Zeitzeugen wie Julian Bigelow (Chefingenieur der Princetonmaschine), Stanley Frankel und Stanislaw Ulam (beide Kernforschungszentrum Los Alamos national laboratory, New Mexico), die allerdings erst Jahrzehnte später gemacht wurden (siehe Brian Jack Copeland (Hg.): The essential Turing, Clarendon press, Oxford 2004, Seiten 21-27, und Brian Jack Copeland (Hg.): Alan Turing's electronic brain, Oxford university press, Oxford 2012, Seiten 114-117). Haigh lehnt dieses Unterfangen jedoch ab (siehe Thomas Haigh: Actually, Turing did not invent the computer, in: Communications of the ACM, Band 57, 2014, Heft 1, Seiten 36-41).

\section{John von Neumann}

John von Neumann hat mit seinen Abhandlungen zum Rechnerbau und zum Speicherprogramm (1945 und 1946) die Entwicklungsgeschichte des Computers entscheidend mitgeprägt. Die in Princeton entwickelte Röhrenmaschine, der IAS-Rechner (Institute for advanced study), war erst 1952 einsatzfähig. Trotzdem wurde der speicherprogrammierte Parallelrechner weltweit vielfach nachgebaut. Den Durchbruch des Speicherprogramms verdanken wir in erster Linie von Neumann.

Turings Schrift zur universellen Turingmaschine erschien 1936/37. Die ersten speicherprogrammierten Rechner wurden jedoch erst 1948 in den USA und in England fertig gestellt. Von Neumann war zweifellos der einflussreichste frühe Informatikpionier. Das ist auf nicht zuletzt auf seine weltweite Ausstrahlung als Mathematiker zurückzuführen.

\section{Maurice Wilkes}

Der von Maurice Wilkes an der Universität Cambridge entwickelte speicherprogrammierte Röhrenrechner Edsac (1949) hatte als Abkömmling u.a. den kaufmännischen Rechner Leo. Wilkes gilt als Vater der Mikroprogrammierung. Diese Errungenschaft soll allerdings Turing im Entwurf zum Röhrenrechner Ace vorweggenommen haben.

\section{Frederic Williams}

Das 1948 an der Universität Manchester geschaffene speicherprogrammierte Manchester baby war Ausgangspunkt für eine erfolgreiche Rechnerreihe des englischen Herstellers Ferranti. Die Maschinen wurden international angeboten. Ferranti mark 1 war 1951 der erste im Handel erhältliche Elektronenrechner Europas. Frederic Williams und Thomas Kilburn haben die (meist verbreitete) elektrostatische Speicherröhre erfunden. 
Konrad Zuse

Obwohl Konrad Zuses Relaisrechner Z3 (Berlin, 1941) sich durch bemerkenswerte Vorzüge (Lochstreifensteuerung, Dualsystem, Gleitkomma) auszeichnete, hat er international wenige Spuren hinterlassen. Das trifft auch auf die (erst spät veröffentlichte) wegweisende Programmiersprache Plankalkül zu. Zuse war wegen der Ereignisse im dritten Reich lange Zeit abgeschottet. Er hat die erste europäische Firma für den Rechnerbau gegründet, die viele Relais-, Röhren- und Transistorrechner angeboten hat.

\subsubsection{War Ada Lovelace wirklich die erste Programmiererin?}

Luigi Federico Menabrea hat in seinem Bericht über die analytische Maschine von Charles Babbage in Tabellenform ein Programm zur Lösung linearer Gleichungssysteme veröffentlicht. Diese Arbeit entstand aufgrund eines Konferenzvortrags von Babbage in Turin (1840) (siehe Luigi Federico Menabrea: Notions sur la machine analytique de $M$. Charles Babbage, in: Bibliothèque universelle de Genève, 1842, neue Serie, Band 41, Seiten 352-376).

Ada Lovelace hat Menabreas Aufsatz ins Englische übersetzt und mit vielen Anmerkungen ergänzt. Sie beschreibt - ebenfalls in tabellarischer Form - ein Programm zur Berechnung von Bernoulli-Zahlen (siehe Ada Augusta Lovelace: Notes by the translator, for L. F. Menabrea, sketch of the analytical engine invented by Charles Babbage, esq., in: Scientific memoirs, Band 3, Richard und John E. Taylor, London 1843, Seiten 666-731).

Zum 200. Geburtstag (2015) von Ada Lovelace gab es zahlreiche Neuerscheinungen.

\section{Ada Lovelace war die erste Programmiererin}

„The most elaborate program developed by Babbage and Lady Lovelace for this machine was a routine for calculating Bernoulli numbers.“ (siehe Donald E. Knuth; Luis Trabb Pardo: The early development of programming languages, in: Donald E. Knuth (Hg.): Selected papers on computer languages, Center for the study of language and information, Stanford 2003, Seite 5).

Das ausgereifteste Programm, das Babbage und Ada Lovelace für die analytische Maschine geschrieben haben, diente zur Berechnung der Bernoullizahlen.

„There is direct documentary evidence that Ada Lovelace created this table (writing it out in pencil).“ (siehe Thomas J. Misa: Charles Babbage, Ada Lovelace, and the Bernoulli numbers, in: Robin Hammerman; Andrew L. Russell (Hg.): Ada's legacy, Association for computing machinery/Morgan \& Claypool publishers, San Rafael, Kalifornien 2016, Seite 15).

Wie schriftliche Belege beweisen, hat Ada Lovelace diese Tafel [Tabelle mit dem Algorithmus für die Bernoullizahlen] erstellt und mit Bleistift aufgezeichnet. 
„Even if Babbage provided Ada with the mathematical expressions for the Bernoulli numbers, and assisted with the derivation of a general formula, the transformation of the general formula into a step-by-step algorithm remains Ada’s achievement, as the letters clearly indicate.“ (siehe

Thomas J. Misa: Charles Babbage, Ada Lovelace, and the Bernoulli numbers, in: Robin Hammerman; Andrew L. Russell (Hg.): Ada's legacy, Association for computing machinery/Morgan \& Claypool publishers, San Rafael, Kalifornien 2016, Seite 26).

Selbst wenn Babbage Ada die mathematischen Ausdrücke für die Bernoullizahlen bereitgestellt und sie bei der Herleitung einer allgemeinen Formel unterstützt hätte, bleibt die Umwandlung dieser Gleichung in eine Schritt-für-Schritt-Rechenvorschrift Adas Leistung. Das geht aus dem Briefwechsel eindeutig hervor.

„For Note G on the Bernoulli numbers, the table-algorithm has ten data variables, three working variables, and four result variables. The computation has just 25 operations, but there are in addition two nested loops: an outer loop consisting of steps 13-23, and two inner loops consisting of steps 13-16 and 17-20. [...]. Nothing like it appeared in Menabrea's original.“ (siehe Thomas J. Misa: Charles Babbage, Ada Lovelace, and the Bernoulli numbers, in: Robin Hammerman; Andrew L. Russell (Hg.): Ada's legacy, Association for computing machinery/Morgan \& Claypool publishers, San Rafael, Kalifornien 2016, Seite 28).

Die Anmerkung G über die Bernoullizahlen enthält eine Rechenvorschrift in Tabellenform. Sie hat zehn Datenvariablen, drei Variablen für die Zwischen- und vier für die Schlussergebnisse. Die Berechnungen umfassen nur 25 Vorgänge. Zusätzlich gibt es aber zwei verschachtelte Schleifen, eine äußere mit den Schritten 13-23 und zwei innere mit den Schritten 13-16 und 17-20. [...]. Nichts dergleichen ist in Menabreas Urtext zu finden.

„At the least, we can grant her primary authorship of the first algorithm intended for a computing machine.“ (siehe Thomas J. Misa: Charles Babbage, Ada Lovelace, and the Bernoulli numbers, in: Robin Hammerman; Andrew L. Russell (Hg.): Ada's legacy, Association for computing machinery/Morgan \& Claypool publishers, San Rafael, Kalifornien 2016, Seiten 29/30).

Wir können Ada mindestens das Erstrecht zugestehen für die Urheberschaft am ersten Programm, das für eine Rechenmaschine geschrieben wurde.

\section{Ada Lovelace war nicht die erste Programmiererin}

„Lovelace is widely celebrated for a variety of reasons. She is variously described as a mathematical genius, as having a critical influence on the invention of the Analytical Engine, of being the first programmer, and of being a prophet of the computer age. The first two of these are unsupported by evidence of any kind and are readily disproved by the simple chronology of events. The third claim to fame (that she was the first programmer) is understandable but wrong. But the tribute of being a visionary of the computer age justifies as fully deserved the tributes paid to her for otherwise mistaken reasons.“ (siehe Doron D. Swade: Pre-electronic computing, in: Cliff B. Jones; John L. Lloyd (Hg.): Dependable and historic computing, Springer-Verlag, Heidelberg usw. 2011, Seiten 75-76). 
Lovelace wird aus mancherlei Gründen weit und breit gefeiert. Sie wird etwa als überaus schöpferische Mathematikerin beschrieben. Ada soll die Erfindung der analytischen Maschine entscheidend beeinflusst haben, die erste Programmiererin und eine Prophetin des Informatikzeitalters sein. Es gibt keinerlei Belege für die ersten beiden Behauptungen, sie lassen sich schon durch die zeitliche Abfolge der Ereignisse ohne weiteres widerlegen. Der dritte Anspruch auf Ruhm (erste Programmiererin) ist verständlich, aber falsch. Der Ruf als Visionärin des Informatikzeitalters rechtfertigt die ihr ansonsten irrtümlich zuteil gewordene Anerkennung jedoch vollauf.

„The notes contain examples of algorithmic stepwise sequences of operations executed by the notional Analytical Engine to find solutions, what we would now call „programs“, though neither Babbage nor Ada used these terms. The most detailed worked example was a „program“ to compute Bernoulli numbers. So the first published example of a „program“ appeared under Ada's name. While it is edifying to describe her as „the first programmer" and therefore the originator of the practices and prodecures of computational solution by machine, it is misleading to do so. Those familiar with the archival sources are clear that the techniques and examples in the paper were those devised by Babbage much earlier and suggested or supplied by him." (siehe Doron D. Swade: Pioneer profile Ada Lovelace, in: Resurrection. The bulletin of the computer conservation society, Winter 2010/2011, Heft 53, Seite 33).

Adas Notizen enthalten Beispiele von algorithmischen Schritt-für-Schritt-Anweisungen, die durch die entworfene, aber nicht gebaute analytische Maschine abgearbeitet wurden. Diese Vorgaben würden wir heute als „Programm“ bezeichnen, obwohl weder Babbage noch Ada diesen Ausdruck verwendet haben. Das am ausführlichsten ausgestaltete Beispiel war ein „Programm“ für die Berechnung von Bernoullizahlen. Das erste Beispiel eines „Programms“ wurde also unter Adas Namen veröffentlicht. Es ist zwar naheliegend, sie als „erste Programmiererin“ und somit als Wegbereiterin für die maschinelle Lösung von Rechenaufgaben zu beschreiben, das ist aber irreführend. Wer mit den Archivquellen vertraut ist, weiß, dass die im Aufsatz erwähnten Techniken und Beispiele viel früher von Babbage ausgedacht wurden. Er hatte sie ihr offensichtlich vorgeschlagen oder zur Verfügung gestellt.

\section{Folgerungen}

Im Streit zwischen Technikern (Doron Swade, England, und auch Allan Bromley, Australien) und Historikern (Thomas Misa, USA) ist wohl den Ingenieuren beizupflichten: Wie aus Archivdokumenten hervorgeht, sind die Programme zur Lösung linearer Gleichungssysteme und zur Berechnung der Bernoullizahlen wahrscheinlich Babbage zuzuschreiben. Es ist deshalb anzunehmen, dass Ada Lovelace zu Unrecht als Urheberin des ersten Programms gefeiert wird. 


\title{
1.22.4 Die Meinungen zu Turings Einfluss auf den Rechnerbau gehen auseinander
}

\author{
Turings Einfluss auf den Rechnerbau wird überschätzt (vgl. Kasten).
}

\section{Wie groß war Turings Einfluss auf die frühen britischen Rechenautomaten?}

Was für Spuren hat Turing hinterlassen?

- Post office research station, Dollis Hill (Nordwest-London)

Anlass für die Herstellung des Röhrenrechners Colossus (1943) waren die mit der deutschen Lorenz-Schlüsselmaschine angefertigten Geheimmeldungen. Verantwortlich war Thomas Flowers. Obwohl der Koloss bis 1975 geheim war, beeinflusste er offenbar die Bemühungen an der Universität Manchester. Alan Turing war an der Entwicklung des Colossus nicht beteiligt.

- National physical laboratory, Teddington (London) Alan Turing entwarf 1945 für John Womersley einen speicherprogrammierten Röhrenrechner namens Ace. Beim Bau kam es allerdings zu Verzögerungen (Pilot Ace, 1950) (vgl. Abb. 1.14). Der ernüchterte Turing wechselte vor dessen Fertigstellung an die Universität Manchester.

- Universität Cambridge

Maurice Wilkes erhielt von Douglas Hartree einen kurzen Einblick in die wegweisende Abhandlung über den Von-Neumann-Rechner (1945). Diese Schrift war im Zusammenhang mit dem Elektronenrechner Eniac entstanden. Ein Besuch einer Vortragsreihe an der Universität von Pennsylvania in Philadelphia (1946) festigte seinen Entschluss zum Rechnerbau. Die speicherprogrammierte Röhrenmaschine Edsac wurde 1949 vollendet.

- Universität Manchester

In Bletchley Park hatte Max Newman die Leistungsfähigkeit digitaler Rechenmaschinen erkannt. Er schlug 1945 der Universität Manchester die Entwicklung eines Elektronenrechners vor und machte auf die Existenz des Colossus aufmerksam. Das von Frederic Williams und Thomas Kilburn gebaute speicherprogrammierte Manchester baby erblickte 1948 das Licht der Welt. Kilburn hatte 1946/47 eine Lehrveranstaltung zum Rechnerentwurf von Wilkinson und Turing besucht. Der Manchester Versuchsrechner lief erstmals im Juni 1948, Alan Turing kam erst im September 1948 an die Universität Manchester. Zu diesem Zeitpunkt war das Vorhaben schon weit fortgeschritten.

\section{Erläuterungen}

Die bahnbrechende Arbeit über die (universelle) Turingmaschine wurde 1936/37 veröffentlicht. Von diesem theoretischen Modell bis zu Turings Entwurf des Röhrenrechners Ace (1945) vergingen viele Jahre. Der stecktafelgesteuerte Colossus (1943) war nicht speicherprogrammiert. Die Bedeutung der zukunftsträchtigen Digitalrechner wurde Wilkes anscheinend erst über den Umweg über die USA bewusst. Bei Ace steht ein unmittelbarer Einfluss Turings fest. In Manchester, wo er die Vorgaben für die Ein- und Ausgabe festlegte und das Programmierhandbuch schrieb, ist seine Handschrift weniger deutlich. Die in Cambridge und Manchester gebauten speicherprogrammierten Maschinen entsprechen der Von-Neumann-Bauweise. 


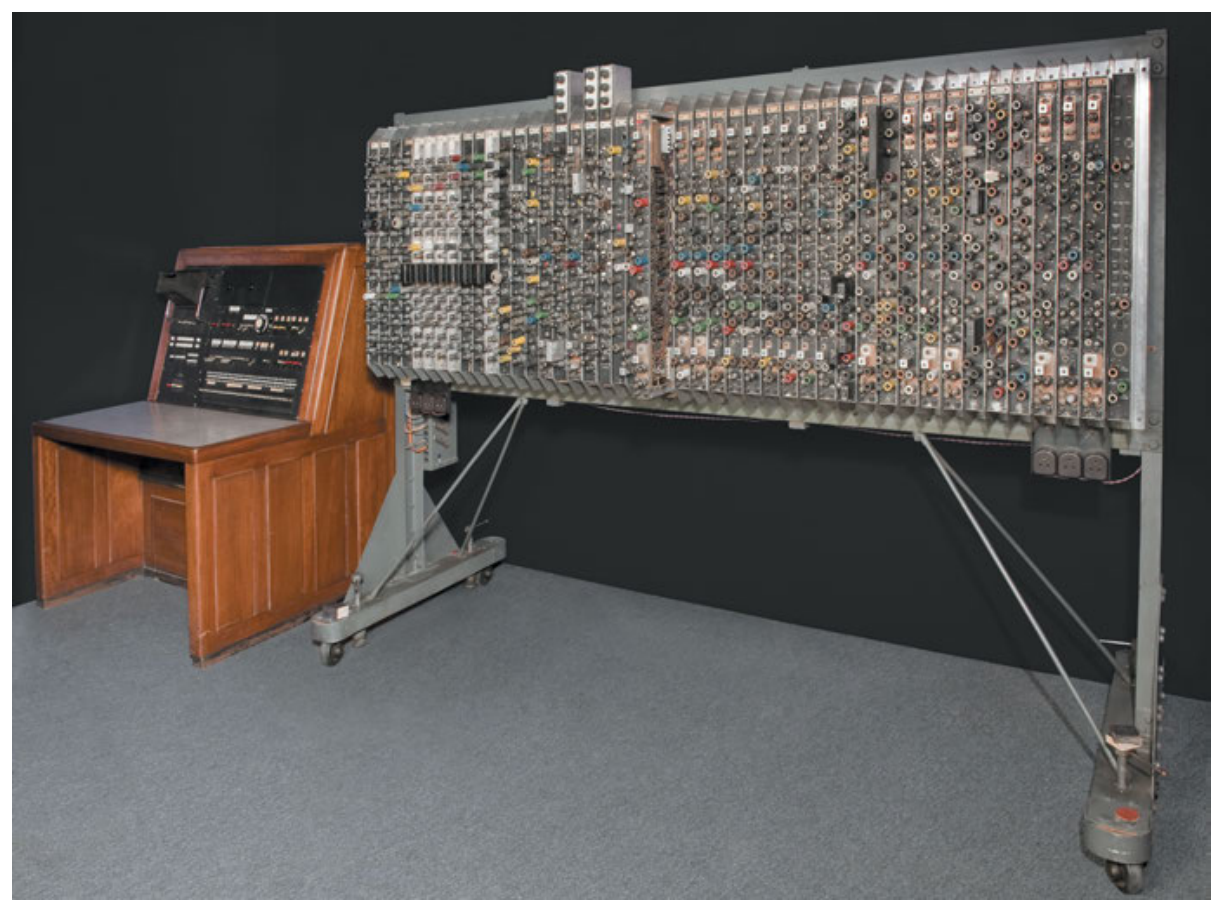

Abb. 1.14: Pilot Ace. Alan Turing entwarf am National physical laboratory in London den Elektronenrechner Automatic computing engine (Ace). 1950 war das abgemagerte, arbeitsfähige Versuchsmuster nach großen Verzögerungen fertig gestellt. Zu diesem Zeitpunkt war der Erfinder allerdings bereits an der Universität Manchester. Ace ist das Gegenstück zu John von Neumanns Edvac. Die Firma English electric (Stafford) entwickelte die speicherprogrammierte Maschine weiter und bot sie ab 1955 unter dem Markennamen Deuce an. Pilot Ace ist einer der wenigen erhaltenen elektronischen Digitalrechner aus der Frühzeit (® Science Museum, London/Science \& society picture library).

Bemerkenswert ist die folgende Aussage von Brian Randell:

„They [Williams and Kilburn] learned from Newman the basic principles of von Neumann's stored-program computer which was then fully designed but not yet operative [...].“ (siehe Brian Randell: The colossus, in: Nicholas Constantine Metropolis; Jack Howlett; Gian-Carlo Rota (Hg.): A history of computing in the twentieth century, Academic press, New York, London usw. 1980, Seite 86).

Max Newman unterrichtete [1946] Frederic Williams und Thomas Kilburn von der Universität Manchester über die Grundzüge des speicherprogrammierten Von-Neumann-Rechners. Diese Maschine war damals schon voll durchdacht, aber noch nicht betriebsfähig.

Goldstine, Mitarbeiter von Neumanns, geht davon aus, dass vor allem die Reisen britischer Wissenschaftler in die USA den Rechnerbau in England ausgelöst haben: 


\begin{abstract}
„It is however remarkable that Great Britain had such vitality that it could immediately after the war embark on so many well-conceived and well-executed projects in the computer field. These include the construction by Wilkes of the Edsac at Cambridge, by Williams of Madm and its successors at Manchester, by Turing (and his successors) at Teddington, and by Booth at Birkbeck College, London [...]. Out of these developments, which essentially started with the visits of Hartree and of Womersley, grew a considerable industry in Britain.“ (siehe Herman Goldstine: The computer from Pascal to von Neumann, Princeton university press, Princeton, New Jersey 1993, Seite 321).
\end{abstract}

Es ist indessen bemerkenswert, dass sich Großbritannien sofort nach dem Krieg mit solcher Energie in so viele gut geplante und gut umgesetzte Rechnervorhaben eingelassen hat. Sie umfassen den Bau des Edsac in Cambridge durch Wilkes, die Herstellung mehrerer Digitalautomaten in Manchester durch Williams und in Teddington durch Turing (und seine Nachfolger) sowie durch Booth am Londoner Birkbeck college [...]. Diese Unternehmungen, die im Wesentlichen mit Hartrees und Womersleys [USA-]Besuchen begannen, führten zu einer beachtlichen englischen Industrie.

Douglas Hartree wirkte zunächst an der Universität Manchester, später in Cambridge, John Womersley am National physical laboratory in Teddington (London). Der britische Tatendrang lässt sich teilweise durch die mit dem Colossus gewonnenen Erkenntnisse erklären.

Goldstine, dem der Colossus damals wahrscheinlich nicht bekannt war, stellt fest:

„During this same eventful spring and summer a number of British visitors came to the Moore School, and from these visits stemmed the computerization of Great Britain. Specifically, they resulted in the development and construction of machines at the National Physical Laboratory, Teddington - the ACE, automatic computing engine; at Cambridge University - the Edsac, electronic delay storage automatic calculator; and at the University of Manchester - Madm, Manchester automatic digital machine.“ (siehe Herman Goldstine: The computer from Pascal to von Neumann, Princeton university press, Princeton, New Jersey 1993, Seite 217).

Während des gleichen ereignisreichen Frühlings und Sommers [1945] kamen mehrere englische Besucher an die Moore school [Philadelphia]. Auf diese Besuche ist der Rechnerbau in Großbritannien zurückzuführen. Sie hatten insbesondere die Entwicklung und die Fertigung von Maschinen im National physical laboratory, Teddington (ACE), an der Universität Cambridge (Edsac) und der Universität Manchester (Madm) zur Folge.

Diese Auffassung teilt Martin Campbell-Kelly:

„From Britain, Maurice Wilkes attended on behalf of Cambridge University and David Rees for Manchester. The Moore school lectures had the effect of establishing the stored-program computer as the big idea in computing and after the lectures computing groups in America and Britain set to work to turn the design into a reality." (siehe Martin Campbell-Kelly: The Ace and the shaping of British computing, in: Brian Jack Copeland (Hg.): Alan Turing's electronic brain, Oxford 2012, Seite 152). 
Aus Großbritannien nahmen Maurice Wilkes und David Rees im Namen der Universität Cambridge bzw. Manchester teil. Die Vortragsreihe an der Moore school verhalf dem speicherprogrammierten Rechner zum Durchbruch. Nach der Veranstaltung begannen Arbeitsgruppen in Amerika und Großbritannien mit der Umsetzung des Vorhabens.

Campbell-Kelly ergänzt:

„The modern computer is based on the Edvac, which owed very little to the design of Eniac and absolutely nothing to the Colossus." (siehe Martin Campbell-Kelly: The Ace and the shaping of British computing, in: Brian Jack Copeland (Hg.): Alan Turing's electronic brain, Oxford university press, Oxford 2012, Seiten 152/153).

Der moderne Digitalrechner baut auf dem Edvac auf. Dieser verdankt der Gestaltung des Eniac sehr wenig und dem Colossus gar nichts.

Außer dem (seriellen) Edvac (mit Umlaufspeicher) gab es ein weiteres Vorbild: die (parallele) Princetonmaschine (mit elektrostatischem Speicher).

Britische und nordamerikanische Historiker stufen von Neumanns Edvac-Bericht so ein:

„His report, entitled A first draft of a report on the Edvac, dated 30 June 1945, was the seminal document describing the stored-program computer. It offered the complete logical formulation of the new machine and ultimately was the technological basis for the worldwide computer industry." (siehe Martin Campbell-Kelly; William Aspray; Nathan Ensmenger; Jeffrey R. Yost: Computer. A history of the information machine, Westview press, Boulder, Colorado, 3. Auflage 2016, Seite 77).

Von Neumanns Abhandlung mit der Überschrift „A first draft of a report on the Edvac“ vom 30. Juni 1945 war die zukunftsträchtige Arbeit zum speicherprogrammierten Rechner. Sie vermittelte eine vollständige logische Beschreibung der neuen Maschine und war schließlich die technische Grundlage für die weltweite Informatikindustrie.

Der britische Informatikhistoriker Lavington schreibt:

„Successors to Colossus were built, but it is not thought that these developments contributed in any significant way to the design of general-purpose stored-program computers." (siehe Simon Lavington: Early British computers, Manchester university press, Manchester 1980, Seite 53).

Es wurden Colossus-Nachfolger gebaut. Man nimmt aber nicht an, dass diese Entwicklungen wesentlich zum Entwurf des programmgespeicherten Universalrechners beigetragen haben.

Campbell-Kelly fasst zusammen:

„The place of the universal Turing machine in the history of computing is difficult to assess at the present time. This is particularly so in Britain where Turing has become lionized, and many people feel that the Turing machine just has to be one of the foundations of computing. The 
story is very complex, and we will probably not resolve it for many years. In all my researches on the early history of computing, I cannot recall a direct reference to the Turing machine in the context of computer design. My own view is that the Turing machine was really a fairly abstruse branch of mathematics that was only appropriated by computing about a decade after the first machines were built when computer scientists first began to study computability." (siehe Martin Campbell-Kelly: The Ace and the shaping of British computing, in: Brian Jack Copeland (Hg.): Alan Turing's electronic brain, Oxford university press, Oxford 2012, Seite 153).

Die Stellung der Turingmaschine in der Informatikgeschichte lässt sich zurzeit nur schwer beurteilen. Das gilt vor allem im Vereinigten Königreich, wo Turing als Held gefeiert wird. Manche glauben, dass die Turingmaschine eine der Grundlagen der Informatik sein muss. Die Angelegenheit ist sehr vielschichtig, und wir werden sie wahrscheinlich viele Jahre lang nicht bewältigen können. Ich kann mich nicht daran erinnern, dass in allen meinen Nachforschungen zur Frühgeschichte der Informatik im Zusammenhang mit dem Rechnerentwurf je ein direkter Hinweis auf die Turingmaschine aufgetaucht ist. Nach meiner persönlichen Meinung war die Turingmaschine ein ziemlich verworrener Zweig der Mathematik. Er wurde in der Informatik erst etwa ein Jahrzehnt nach dem Bau der ersten Maschinen beachtet, als man anfing, sich mit der Berechenbarkeit auseinanderzusetzen.

In der Frühzeit des Rechnerbaus wird die Turingmaschine auch im deutschsprachigen Raum kaum je gewürdigt. Im Grundlagenwerk von Heinz Rutishauser, Ambros Speiser, Eduard Stiefel: Programmgesteuerte digitale Rechengeräte (elektronische Rechenmaschinen), Birkhäuser Verlag, Basel 1951, sind keine Hinweise zur Turingmaschine zu finden. In seiner Schrift Automatische Rechenplanfertigung bei programmgesteuerten Rechenmaschinen, Birkhäuser Verlag, Basel 1952, erwähnt Rutishauser zwar Aiken, Kilburn, von Neumann, Wilkes und Zuse, nicht aber Turing. Er kannte den Plankalkül, wusste aber wohl nichts von Turings schwerverständlicher Arbeit (1936).

Turings Einfluss auf die frühe Rechnerentwicklung bei Elliott Brothers (Borehamwood) war offenbar gering. Dazu bemerkt Simon Lavington:

\footnotetext{
„There is abundant evidence that Cambridge, and especially Maurice Wilkes who became an Elliott consultant, provided an on-going inspiration for Borehamwood. [...]. As for the great logico-mathematicians Alan Turing and Max Newman, their influence on Borehamwood's computing endeavours appears to have been minimal." (siehe Simon Lavington: Swords and ploughshares: Connections between computer projects for war and peace, 1945-55, in: Cliff B. Jones; John L. Lloyd (Hg.): Dependable and historic computing, Springer-Verlag, Heidelberg usw. 2011, Seiten 316-317).
}

Es gibt viele Belege, dass Cambridge und vor allem Maurice Wilkes, der ein Berater von Elliott wurde, Borehamwood immer wieder Anregungen vermittelte [...]. Der Einfluss der großen mathematischen Logiker Alan Turing und Max Newman auf den Rechnerbau in Borehamwood scheint hingegen gering zu sein. 
[...]. „I do remember going to the first two of the series of lectures that he [Turing] gave in the Ministry of Supply building in London at the end of 1946 and the beginning of 1947. [...]. I did not believe that computers would develop along the lines that Turing was advocating, and for this reason I stopped going to his lectures. [...]. I did not see eye to eye with Turing on computer architecture [...]. The Edsac project was, however, by this time well under way, and it was becoming abundantly clear that it would be in everyone's interest that we should proceed independently.“ (siehe Maurice Vincent Wilkes: Memoirs of a computer pioneer, MIT press, Cambridge, Massachusetts, London 1985, Seiten 135-137).

[...]. Ich [Wilkes] erinnere mich, dass ich die ersten beiden Vorträge von Turings Vorlesungsreihe besucht habe, die er Ende 1946 und Anfang 1947 in London im Gebäude des Versorgungsministeriums hielt. [...]. Ich glaubte nicht, dass sich die Rechenautomaten nach Turings Vorstellungen entwickeln würden, und daher brach ich die Teilnahme an den Vorträgen ab. [...]. Unsere Ansichten zum Rechnerbau ließen sich nicht unter einen Hut bringen. [...]. Das Vorhaben Edsac war zu dieser Zeit jedoch bereits ziemlich fortgeschritten, und es wurde immer klarer, dass wir beide unabhängig voneinander weitermachen sollten. - Es kam in der Folge nicht zu einer Zusammenarbeit zwischen London und Cambridge.

Turing: universelle Rechenmaschine und Speicherprogramm

Francis Morley Colebrook, Leiter der Elektronikabteilung des Londoner National physical laboratorys (Teddington, Middlesex), leitete seinen Vortrag auf der internationalen Konferenz zu Rechenmaschinen in Paris 1951 wie folgt ein:

„En 1936, la London Mathematical society publia dans ses comptes-rendus une étude du docteur A. M. Turing intitulée „Sur les nombres calculables, avec application au problème d'Entscheidung“. Cette étude est peut-être la première à d'écrire en termes généraux un calculateur automatique universel arithmétique. C'est pourtant une étude des plus abstraites et elle ne laisse, en aucun point, prévoir les types de machine désignés maintenant sous le nom de calculateurs automatiques universels arithmétiques. Néanmoins, elle suscita l'intérêt de M. J. R. Womersley qui inaugura le projet Ace lors de son arrivée au N.P.L. en 1944; on peut bien regarder l'étude en question comme le point de départ de l'Ace. Turing lui-même vint travailler au N.P.L. en 1945 et se mit à l'étude de ce qu'on appelle la structure logique de la machine avec le concours de quelques-uns de ses collègues de la Mathematics division.“ (siehe Francis Morley Colebrook: Le modèle pilote du calculateur automatique électronique arithmétique (Ace) du NPL, in: Joseph Pérès (Hg.): Les machines à calculer et la pensée humaine, Paris, 8-13 janvier 1951, Colloques internationaux du Centre national de la recherche scientifique, Editions du Centre national de la recherche scientifique, Paris 1953, Seite 65).

Die Londoner Mathematische Gesellschaft veröffentlichte 1936 in ihrem Tagungsband eine Abhandlung von Alan Mathison Turing unter der Überschrift „On computable numbers, with an application to the Entscheidungsproblem“ (Über berechenbare Zahlen, mit einer Anwendung auf das Entscheidungsproblem). Das ist vielleicht der erste Aufsatz, der einen universellen Rechenautomaten allgemeinen beschreibt. Es handelt sich jedoch um eine schwer verständliche, äußerst theoretische Untersu- 
chung. Sie lässt in keiner Weise die Art von Maschinen voraussehen, die jetzt als universelle Rechenautomaten bezeichnet werden. Dennoch erweckte sie die Aufmerksamkeit von John Ronald Womersley, der 1944 bei der Aufnahme seiner Arbeit im National physical laboratory (NPL) das Vorhaben Ace in die Wege leitete. Man kann die erwähnte Abhandlung durchaus als Ausgangspunkt für Ace betrachten. Turing selbst kam 1945 ans NPL, wo er mit Unterstützung einiger seiner Kollegen der Mathematikabteilung den logischen Aufbau der Maschine entwarf.

\section{Anmerkung}

Colebrook erwähnt im Zusammenhang mit Alan Turing das Speicherprogramm nicht.

Copeland zufolge beeinflusste Turing Kilburn:

„Tom Kilburn and I knew nothing about computers ... Professor Newman and Mr. A. M. Turing ... knew a lot about computers ... They took us by the hand and explained how numbers could live in houses with addresses. [...]. Turing's direct early input to the developments at Manchester, hinted at by Williams in the preceding quotation, was via the lectures on computer design that Turing and his assistant Jim Wilkinson gave in London between December 1946 and February 1947.“ (siehe Brian Jack Copeland: The Manchester computer: A revised history. Part 2: The baby computer, in: IEEE Annals of the history of computing, Band 33, 2011, Heft 1, Seite 22).

Tom Kilburn und ich hatten keine Ahnung von Elektronenrechnern. Professor Newman and A. M. Turing wussten hingegen viel über Computer. Sie nahmen uns an der Hand und erklärten, wie Zahlen in Häusern mit Adressen leben konnten. [...]. Der unmittelbare frühe Beitrag Turings zu den Entwicklungen in Manchester, die Williams im vorangehenden Zitat anspricht, geschah über die Vorträge zum Rechnerentwurf, die Turing und sein Assistent Jim Wilkinson vom Dezember 1946 bis Februar 1947 in London hielten.

„The lectures were attended by representatives from various organizations that planned to use or build an electronic computer. Kilburn was among the audience.“ (siehe Brian Jack Copeland: The Manchester computer: A revised history. Part 2: The baby computer, in: IEEE Annals of the history of computing, Band 33, 2011, Heft 1, Seite 23).

Vertreter verschiedener Organisationen, die im Sinn hatten, einen Elektronenrechner zu verwenden oder zu bauen, besuchten diese Vorträge. Kilburn war einer der Teilnehmer.

Wang meint zu Turings Einfluss:

„Turing's theory of computable functions antedated but has not much influenced the extensive actual construction of digital computers. These two aspects of theory and practice have been developed almost entirely independently of each other. The main reason is undoubtedly that logicians are interested in questions radically different from those with which the applied mathematicians and electrical engineers are primarily concerned." (siehe Hao Wang: A variant to Turing's theory of computing machines, in: Journal of the Association for computing machinery, Band 4, 1957, Heft 1, Seite 63). 
Turings Theorie der berechenbaren Funktionen hat den weit verbreiteten (praktischen) Bau von Digitalrechnern nur wenig beeinflusst, obwohl sie zeitlich voranging. Die Theorie und die Praxis haben sich nahezu unabhängig voneinander entwickelt. Der Hauptgrund dafür ist zweifellos, dass sich die Logiker mit völlig anderen Fragestellungen befassen als die angewandten Mathematiker und die Elektroingenieure.

Priestley teilt diese Auffassung:

„This idea has been reinforced by Davis, whose writings give the impression that the first storedprogram computers were created by means of a relatively straightforward implementation of Turing's abstract machines.“ (siehe Mark Priestley: A science of operations, Springer-Verlag, London 2011, Seite 125).

Dieser Gedanke [die Entstehung der ersten speicherprogrammierten Rechner - Logikmaschinen - als Nebenprodukt aus theoretischen Untersuchungen zum Wesen und den Grenzen des logischen Denkens] wurde von (Martin) Davis untermauert. Seine Schriften vermitteln nämlich den Eindruck, dass die ersten speicherprogrammierten Rechner gleichsam durch die direkte praktische Umsetzung der abstrakten Turingmaschinen geschaffen wurden.

Daylight vertritt die Ansicht, dass Turings Einfluss auf die Informatikgeschichte (Rechnerbau und Programmierung) überschätzt wird. Bis in die 1950er Jahre sei seine Abhandlung von 1936 offenbar weitgehend unbekannt gewesen (siehe Edgar Graham Daylight: The dawn of software engineering, Heverlee 2012, Seiten 1-6, 13-14, 41-42, 187-197).

\section{Folgerungen}

Turing hatte wohl nur einen geringen Einfluss auf den Rechnerbau. Selbst an den speicherprogrammierten Maschinen Englands war er, vom Elektronenrechner Ace abgesehen, nicht oder nur am Rand beteiligt. Die Konstrukteure der ersten Relaisund Röhrenrechner (Aiken, Atanasoff, Eckert, Lebedew, Mauchly, Stibitz, Zuse) kannten mindestens zu Beginn ihrer Bemühungen Turings wegweisende Gedanken vermutlich nicht. Mit Ausnahme von Lebedew waren ihre frühen Geräte nicht speicherprogrammiert.

Hinweis

Thomas Haigh; Mark Priestley: Historical reflections. Von Neumann thought Turing's universal machine was 'simple and neat.' But that didn't tell him how to design a computer, in: Communications of the ACM, Band 63, Januar 2020, Heft 1, Seiten 26-32.

\subsection{Welches waren die einflussreichsten Rechenanlagen?}

Die folgenden Anlagen beeinflussten die Entwicklung der programmgesteuerten Rechenmaschinen wohl am meisten: 
- $\mathrm{ABC}$ (Iowa state college, Ames, Iowa),

- Colossus (Post office research station, Dollis Hill, London),

- Edvac (Universität von Pennsylvania in Philadelphia),

- Eniac (Universität von Pennsylvania in Philadelphia),

- Harvard mark (Harvard-Universität, Cambridge, Massachusetts),

- IAS-Rechner (Institute for advanced study, Princeton, New Jersey).

Der vergleichsweise kleine Atanasoff-Berry-Rechner ABC gab offenbar ausschlaggebende Anregungen für die Ausgestaltung des Rechenriesen Eniac. Der mühsame Umgang mit diesem Koloss veranlasste den Bau des Edvac. Die Eniac-Erbauer fertigten die binäre Anlage Binac und den erfolgreichen Großrechner Univac.

Zwei Entwicklungslinien haben sich herausgebildet:

- Der serielle Edvac mit Quecksilberlaufzeitspeicher war das Vorbild für den britischen Edsac sowie für Manchester mark, Seac, Binac, Univac usw.

- Der parallele IAS-Rechner mit elektrostatischem Speicher hatte zahlreiche Nachbauten sowohl in den Vereinigten Staaten (Avidac, IBM 701, Illiac, Johnniac, Maniac, Oracle, Ordvac, Swac, Whirlwind) wie auch im Ausland: Besk (Schweden), Dask (Dänemark), Silliac (Australien), Smil (Schweden), Weizac (Israel) usw.

Die Erfahrungen mit dem bis 1975 geheim gehaltenen Colossus regten offensichtlich den Bau des speicherprogrammierten Manchester babys an und prägten auch die Entwicklung des Pilot Ace.

Die im Krieg zerstörte, kaum bekannte Zusemaschine Z3 hat die Entwicklung nicht nachhaltig geprägt. Die Z4 hat die Konstruktion der Schweizer Ermeth gefördert, aber auch verzögert. Als Nachfolgerechner ist die Z5 zu nennen.

Die analytische Maschine von Charles Babbage wirkte sich auf die Arbeit von Leonardo Torres Quevedo aus. Konrad Zuse kannte Charles Babbage lange Zeit nicht (siehe Konrad Zuse: Der Computer - Mein Lebenswerk, Springer-Verlag, Berlin, Heidelberg, 5., unveränderte Auflage 2010, Seite 30). Er erfuhr erst im Zusammenhang mit einer Patentanmeldung zu der Programmsteuerung und den Rechenwerken vom amerikanischen Patentamt von der analytischen Maschine. Howard Aiken, Mitschöpfer der elektromechanischen Rechenmaschine Harvard mark 1/IBM ASCC, hielt sich laut seinem Biografen Bernard Cohen hingegen für den Erben von Babbage.

\subsubsection{Einflussreiche Musterrechner}

Viele große Elektronenrechner folgten einem von zwei Modellen (vgl. Tab. 1.13), der Edvac-Bauweise (Serienrechner mit Laufzeitspeicher), der Princeton- oder IASBauweise (Parallelrechner mit elektrostatischem Speicher). 
Tab. 1.13: Eigenschaften der beiden bedeutenden Modellrechner mit Programmspeicher

\begin{tabular}{|c|c|c|}
\hline \multicolumn{3}{|c|}{ Vergleich von Edvac und IAS-Rechner } \\
\hline Merkmale & Edvac & IAS \\
\hline Serienrechner & [ & \\
\hline Parallelrechner & & $\mathbf{\square}$ \\
\hline Quecksilberspeicher & $\mathbf{\square}$ & \\
\hline elektrostatischer Speicher & & 口 \\
\hline Binärrechner & $\mathbf{\square}$ & $\mathbf{\square}$ \\
\hline Speicherprogramm & $\mathbf{\square}$ & $\mathbf{\square}$ \\
\hline Festkommadarstellung & $\mathbf{\square}$ & $\mathbf{\square}$ \\
\hline
\end{tabular}

(C) Bruderer Informatik, $\mathrm{CH}-9401$ Rorschach 2020

Zeichenerklärung

- ja

\subsection{Welches waren die ersten marktfähigen Rechner?}

$\mathrm{Zu}$ den ersten US-Unternehmen, die Digitalrechner herstellten, gehörten Engineering research associates, Inc. (ERA, St. Paul, Minnesota, ^1946), Eckert-Mauchly computer corporation (EMCC, Philadelphia, Pennsylvania, ^1946, ursprünglicher Name: Electronic control company, Philadelphia), ferner Raytheon manufacturing company (Waltham, Massachusetts) mit dem Raydac (Raytheon digital automatic computer).

In Deutschland entstand die Zuse KG, Neukirchen (Kreis Hünfeld, *1949). Zu den frühen britischen Anbietern zählten Ferranti Ltd. (Moston, Manchester), English electric company Ltd. (Stafford) bzw. English electric computers sowie Elliott brothers (London) Ltd. und Leo computers Ltd. (London).

\subsubsection{Ferranti mark 1 und Univac 1}

Ab 1951 waren in höheren Stückzahlen gefertigte elektronische Digitalrechner erhältlich. Als erster in Serie hergestellter marktgerechter Digitalrechner gilt Ferranti mark 1 (Vertrieb ab Februar 1951, Verkauf von insgesamt 9 Geräten) aus England.

Der nordamerikanische Großrechner Univac 1 (universal automatic computer) von Remington Rand kam einen Monat später, im März 1951, in den Handel. 46 Stück wurden insgesamt abgesetzt.

Ein weiterer verkäuflicher technisch-wissenschaftlicher Rechner war der Binac der Firma EMCC (1 Stück, September 1949). Engineering research associates verkaufte die Maschine Era 1101 (3 Stück, ab Dezember 1950). Beide Firmen wurden später von RemRand übernommen. 


\subsubsection{Leo 1 und IBM 701 bzw. 650}

Der britische Leo 1 (Lyons electronic office 1) ist der erste geschäftlich genutzte europäische Rechner (Erstlauf 1951, Vollendung im Dezember 1953).

Im Frühling 1953 war IBM 701 erhältlich. Ab Ende 1954 wurde die sehr erfolgreiche mittelgroße Anlage IBM 650 (für kaufmännisch-gewerbliche und auch technischwissenschaftliche Anwendungen) ausgeliefert.

\subsubsection{Zuse Z4}

Der Relaisrechner Zuse Z4 (1945) war die erste marktfähige programmgesteuerte Rechenmaschine. Die Relaismaschine Z11 (1956) der Zuse KG ist das erste in Serie gefertigte programmgesteuerte Rechengerät Deutschlands für technisch-wissenschaftliche Anwendungen.

\subsection{Woher kam das Geld?}

In der Frühzeit der Informatik, in den 1930er, 1940er und 1950er Jahren, wurden die meisten Relais- und Röhrenrechner im Auftrag von amerikanischen Regierungsstellen entwickelt. In den Vereinigten Staaten standen somit viel mehr Finanzmittel zur Verfügung als in Europa. Bedeutende Geldgeber waren vor allem die Marine, die Luftwaffe und das Heer der USA. Manche der an den amerikanischen Hochschulen gefertigten programmierbaren Maschinen wurden auf dem entsprechenden militärischen Versuchsgelände eingerichtet. Treibende Kraft für die Konstruktion mathematischer Maschinen waren umfangreiche langwierige Berechnungen beispielsweise für die ballistischen Tabellen, das Knacken verschlüsselter Geheimmeldungen (Kryptologie), die Radartechnik und die Kernenergie. Die Geräte Harvard mark 1/IBM ASCC und Eniac kamen beim Bau der Atombombe bzw. der Wasserstoffbombe zum Einsatz.

Vereinigte Staaten von Amerika (USA)

Die ersten amerikanischen Analog- und Digitalcomputer waren kostspielige Einzelanfertigungen. Hersteller der mächtigen Anlagen waren in der Regel Universitäten (insbesondere Harvard, Philadelphia, MIT). Beteiligt waren auch Unternehmen wie International Business Machines (IBM) und American Telephone and Telegraph company (AT\&T). Die Mehrheit der Maschinenbauer war an der Ostküste angesiedelt. Von der US-Regierung (Verteidigungsministerium) geförderte frühe Großrechner waren Bihac, Eniac, Era 1101, Harvard mark 2 und 3, Seac. Der ab 1953 ausgelieferte Wissenschaftsrechner IBM 701, der erste in Serie gefertigte elektronische Digitalrechner des blauen Riesen, hieß ursprünglich „defense calculator“ (Verteidigungsrechner). Die militärische Unterstützung ging im kalten Krieg vorerst weiter. 
Die beiden 1946 gegründeten Firmen Eckert-Mauchly computer corporation (EMCC) und Engineering research associates (ERA) waren nicht überlebensfähig und wurden im Februar 1950 bzw. Dezember 1951 von Remington Rand (Norwalk, Connecticut) übernommen.

Bald wagten außer Remington Rand und IBM andere große, alt eingesessene Anbieter wie Burroughs, General Electric (GE), National Cash Register (NCR) und Radio Corporation of America (RCA) den Sprung ins kalte Wasser. Weniger zurückhaltend als die Großunternehmen waren neben EMCC und ERA weitere kleine, neue Betriebe, z.B. Computer research corporation (CRC), Consolidated electrodynamics corporation (CEC). Viele verschwanden wieder von der Bildfläche oder zogen sich vom Rechnermarkt zurück.

Großbritannien (Vereinigtes Königreich)

Die obigen Befunde treffen weitgehend auch auf Großbritannien zu. An der Spitze der Forschung sind die Universitäten Manchester, Cambridge und London zu finden. Weitere staatliche Forschungseinrichtungen wie die Post office research station (Spezialmaschine Colossus) und das National physical laboratory (Röhrenrechner Ace) befassten sich mit dem Rechnerbau. Zu nennen sind ferner die Forschungsstätten Telecommunications research establishment (Röhrengerät Treac) und Atomic energy research establishment (Relaisanlage Harwell). Der erste kommerzielle Anbieter von elektronischen Digitalrechnern war wie erwähnt Ferranti.

\section{Deutschland}

Deutsche Hochschulen (Aachen, Darmstadt) widmeten sich zunächst der Herstellung von analogen Integrieranlagen. Konrad Zuse hatte auch Kriegsaufträge. Er wurde für die digitalen Relaisrechner Z3 und Z4 von der Deutschen Versuchsanstalt für Luftfahrt bzw. vom Reichsluftfahrtministerium unterstützt. Für seine Spezialrechner S1 und S2 stand Zuse im Sold der Henschel-Flugzeugwerke. Die ersten bedeutenden Aufträge für die 1949 geschaffene Zuse KG stammen von der ETH Zürich und der Remington Rand, Zürich.

\section{Schweden, Niederlande, Frankreich und Sowjetunion}

Ähnliche Verhältnisse sind in Schweden und den Niederlanden zu beobachten. Der Relaisrechner Bark entstand unter der Federführung der schwedischen Behörde für Rechenmaschinen und des königlichen Telegrafenamts.

Die niederländische Relaismaschine Arra war das Kind des Mathematisch centrums Amsterdam. Das Relaisgerät Arco ist der Technischen Universität Delft zu verdanken. Schließlich war beim Rechner Ptera (PTT electronische reken-automaat, 1953) ein Betrieb der Fernmeldetechnik (PTT) mit von der Partie.

Hinter den erfolglosen Bemühungen Couffignals für einen französischen Rechenautomaten steckte das Centre national de la recherche scientifique (CNRS). Die frühen sowjetischen Elektronenrechner entstanden, soweit bekannt, an universitären Einrichtungen oder wurden vom Staat finanziert. 


\section{Australien und Japan}

Für das erste speicherprogrammierte Gerät Australiens (Csirac) (vgl. Abb. 1.15) war die Commonwealth scientific and industrial research organization (CSIR) in Sydney verantwortlich. Das Elektrotechnische Labor (ETL), Roppongi (später Tsukuba), entwarf den ersten japanischen Relaisrechner.

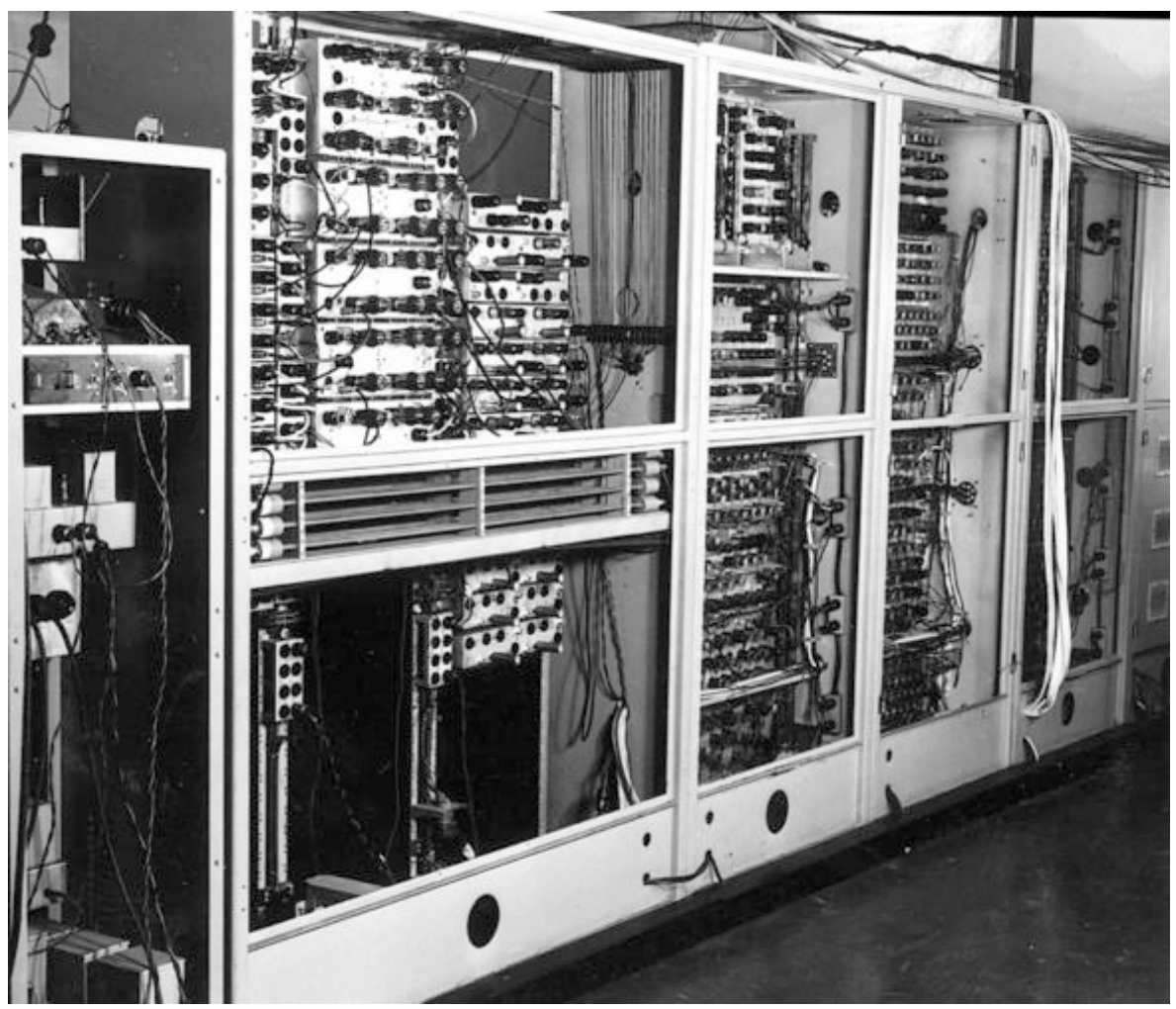

Abb. 1.15: Röhrenrechner Csirac. Der Elektronenrechner der Commonwealth scientific and industrial research organization nahm 1949 in Sydney seinen Versuchsbetrieb auf. Er hatte einen Quecksilberspeicher und eine Magnettrommel. Die speicherprogrammierte australische Maschine gehört zu den wenigen überlebenden Großrechnern aus der Pionierzeit (@ Museums Victoria, Melbourne).

Für weitere Angaben vgl. die folgenden Untersuchungen:

James Cortada: The digital flood. The diffusion of information technology across the U.S., Europe and Asia, Oxford university press, Oxford, New York 2012,

Kenneth Flamm: Creating the computer. Government, industry, and high technology, The Brookings Institution, Washington, D.C. 1988. 


\subsection{Misserfolge beim Rechnerbau}

In der Geschichte der Rechentechnik, der Datenverarbeitung und der Informatik sind viele Rückschläge zu verzeichnen. Es erstaunt nicht, dass bei der Entwicklung hoch komplexer Geräte und Programme nicht immer alles rund läuft. Irrwege lassen sich nicht vermeiden, Schwierigkeiten nicht immer voraussehen. Die Gründe fürs Scheitern sind vielfältig: Geldsorgen, Zeitnot, Personalprobleme, Fehlplanung, Führungsmängel, ungenügende technische Voraussetzungen, unüberwindbare technische Schwierigkeiten, zu geringe Kenntnisse in der Fertigung, mangelnde Nachfrage usw. Bei den mechanischen Rechenmaschinen wird der Misserfolg ab und zu mit der zu wenig fortgeschrittenen Feinmechanik erklärt. Veröffentlichungen über abgebrochene, misslungene Entwicklungen sind selten. Man erfährt selbst bei einer erfolgreichen Vollendung kaum etwas über die Hindernisse, die zu überwinden waren.

Einige zufällige Beispiele: Blaise Pascals Addier- und Subtrahiermaschinen sollen nur mangelhaft gearbeitet haben. Bei den Rechenmaschinen von Gottfried Wilhelm Leibniz wird vielfach angeführt, dass sie am durchgehenden Zehnerübertrag krankten. Neue Nachbauten widerlegen offenbar diese Aussage teilweise. Der verbitterte Charles Babbage konnte weder die Differenzen- noch die analytische Maschine vollenden. Hier waren aber nicht feinmechanische Probleme - wie oft behauptet ausschlaggebend.

Der unter Leitung von Louis Couffignal entwickelte französische binäre Parallelrechner kam nie zum Laufen. Beim Darmstädter elektronischen Rechenautomaten Dera verzichtete man auf einen Dauerbetrieb. Die Entwicklung der Transistormaschine D5 (Dresden) wurde abgebrochen, die Weiterentwicklung des Röhrenrechners ICCE2 des Londoner Imperial college aufgegeben.

Die am Mathematisch Centrum in Amsterdam von Carel Scholten und Bram Jan Loopstra 1952 fertig gestellte Relaismaschine Arra 1 war unbrauchbar, sie versagte im Betrieb. Standard Elektrik Lorenz strich nach der Vollendung ihres einzigen Transistorrechners ER 56 die Segel.

Die kanadische Universität Toronto baute den Parallelrechner Utec, brach jedoch das Vorhaben ab und kaufte einen Ferranti-Rechner (Modell 1).

\section{Verlust von Dokumenten und Objekten}

Die Bewahrung des technischen Kulturguts lässt oft zu wünschen übrig: Die Dokumente wurden vernichtet, die Geräte verschrottet, elektronische Daten sind unlesbar. Oder bei der Lagerung der Schriftstücke und der Gegenstände mangelte es an Sorgfalt und Pflege.

Viele Geräte verfaulten, verrosteten, zerbrachen, waren abgenutzt oder unbrauchbar. Manche Maschinen kamen abhanden (Schwilgués Kirchenrechnermodell), verbrannten (Schickards Rechenuhr, mehrere Figurenautomaten, Schachtürke), gingen im Meer unter (Räderwerk von Antikythera), wurden angeblich eigenhändig vom 
Erfinder (Polenis Sprossenradmaschine) oder im Krieg (Zuse Z3) zerstört, um nur einige Beispiele zu nennen.

Erfolg trotz Pech

Dank der Funde im Hochschularchiv der ETH Zürich gelang es, den bisher unbekannten Ablauf bei der Herstellung des ersten Schweizer Elektronenrechners Ermeth nachzuzeichnen, für weitere Angaben vgl. Abschnitt 4.2.

\subsection{Maschinen mit Schreibwerk}

Sprechen, Schreiben, Lesen, Rechnen sind grundlegende Kulturtechniken. Geräte für das Zählen und Rechnen sind viel älter als schreibende Maschinen. Diese Maschinen erscheinen erst mit Verspätung (vgl. Tab. 1.14).

Tab. 1.14: Schreibautomaten mit Handschrift und Rechenmaschinen mit Druckschrift

\begin{tabular}{|c|c|c|c|c|}
\hline \multicolumn{5}{|c|}{ Frühe Maschinen mit Schreibwerk } \\
\hline Bezeichnung & Erfinder & Land & Jahr & Merkmal \\
\hline $\begin{array}{l}\text { Allesschreibende } \\
\text { Wundermaschine }\end{array}$ & Friedrich Knaus & Deutschland & 1760 & $\begin{array}{l}\text { programmierbarer Schreib- } \\
\text { automat mit Gänsefeder } \\
\text { (Androide mit externer } \\
\text { Mechanik) }\end{array}$ \\
\hline $\begin{array}{l}\text { Schriftsteller } \\
\text { (L'écrivain) }\end{array}$ & $\begin{array}{l}\text { Pierre } \\
\text { Jaquet-Droz }\end{array}$ & Schweiz & 1772 & $\begin{array}{l}\text { programmierbarer Schreib- } \\
\text { automat mit Gänsefeder } \\
\text { (Androide mit interner } \\
\text { Mechanik) }\end{array}$ \\
\hline Differenzenmaschine & $\begin{array}{l}\text { Georg und } \\
\text { Edvard Scheutz }\end{array}$ & Schweden & 1853 & $\begin{array}{l}\text { druckende Rechen- } \\
\text { maschine (für } \\
\text { mathematische Tafelwerke) }\end{array}$ \\
\hline Addiermaschine & $\begin{array}{l}\text { William } \\
\text { Burroughs }\end{array}$ & USA & 1888 & $\begin{array}{l}\text { druckende Addiersegment- } \\
\text { maschine }\end{array}$ \\
\hline elektromechanisches & Leonardo & Spanien & 1920 & elektromechanische \\
\hline Arithmometer & $\begin{array}{l}\text { Torres } \\
\text { Quevedo }\end{array}$ & & & $\begin{array}{l}\text { Rechenmaschine mit Schreib- } \\
\text { maschine für } \\
\text { Ein- und Ausgabe }\end{array}$ \\
\hline
\end{tabular}

(c) Bruderer Informatik, $\mathrm{CH}-9401$ Rorschach 2020

Knaus (vgl. Abb. 1.16) hat mehrere Schreibautomaten hergestellt, die Jaquet-Droz (vgl. Abb. 1.17) haben verschiedene Androiden gebaut. Ein Meisterwerk von Timothy Williamson (vgl. Abb. 1.18) ging nach China. 


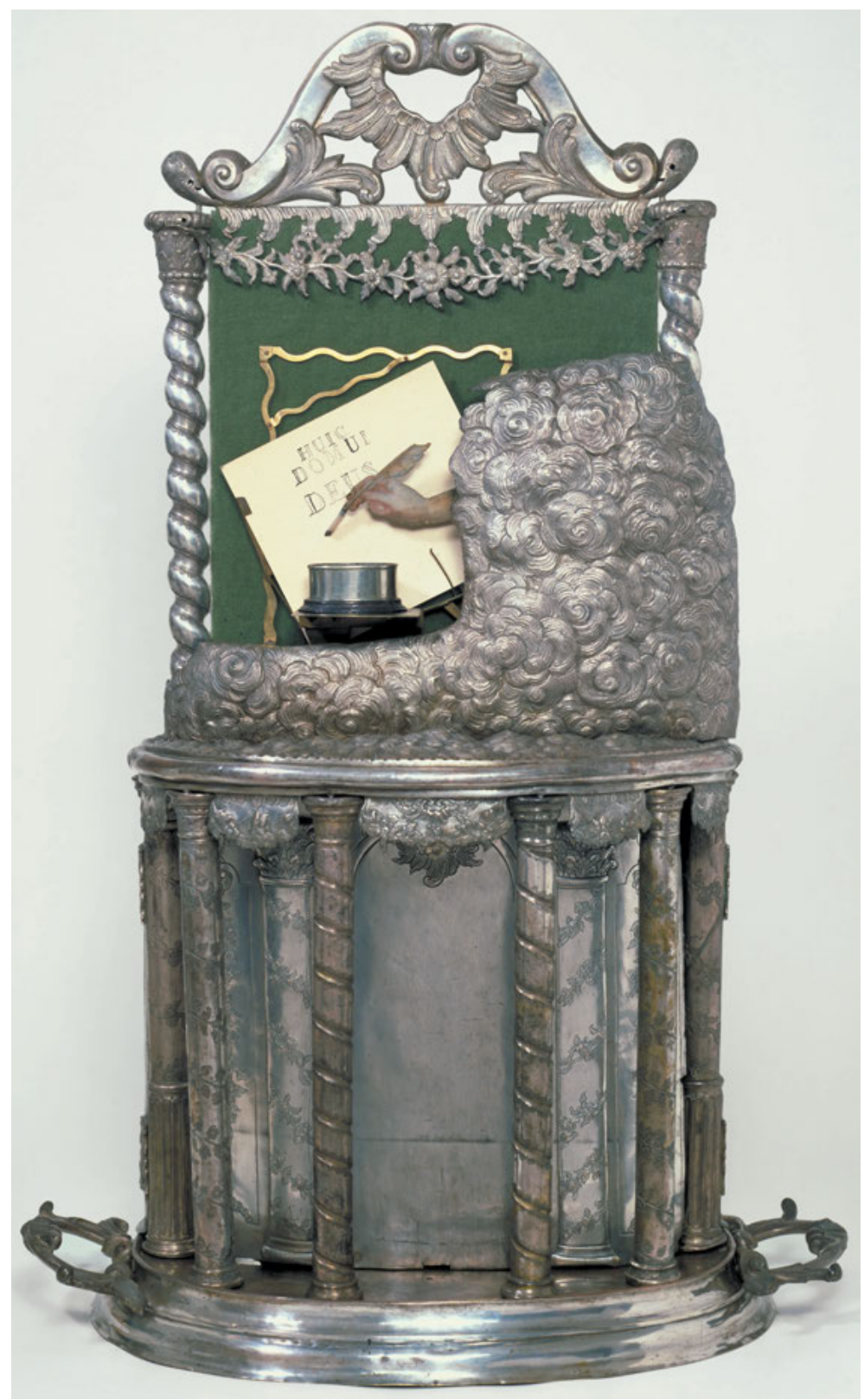

Abb. 1.16: Handschriftautomat von Friedrich Knaus. Der Federkiel dieser Maschine wird wie von Geisterhand gesteuert. Die Mechanik ist im unteren Teil der Maschine verborgen (C) Museo Galileo, Florenz). 


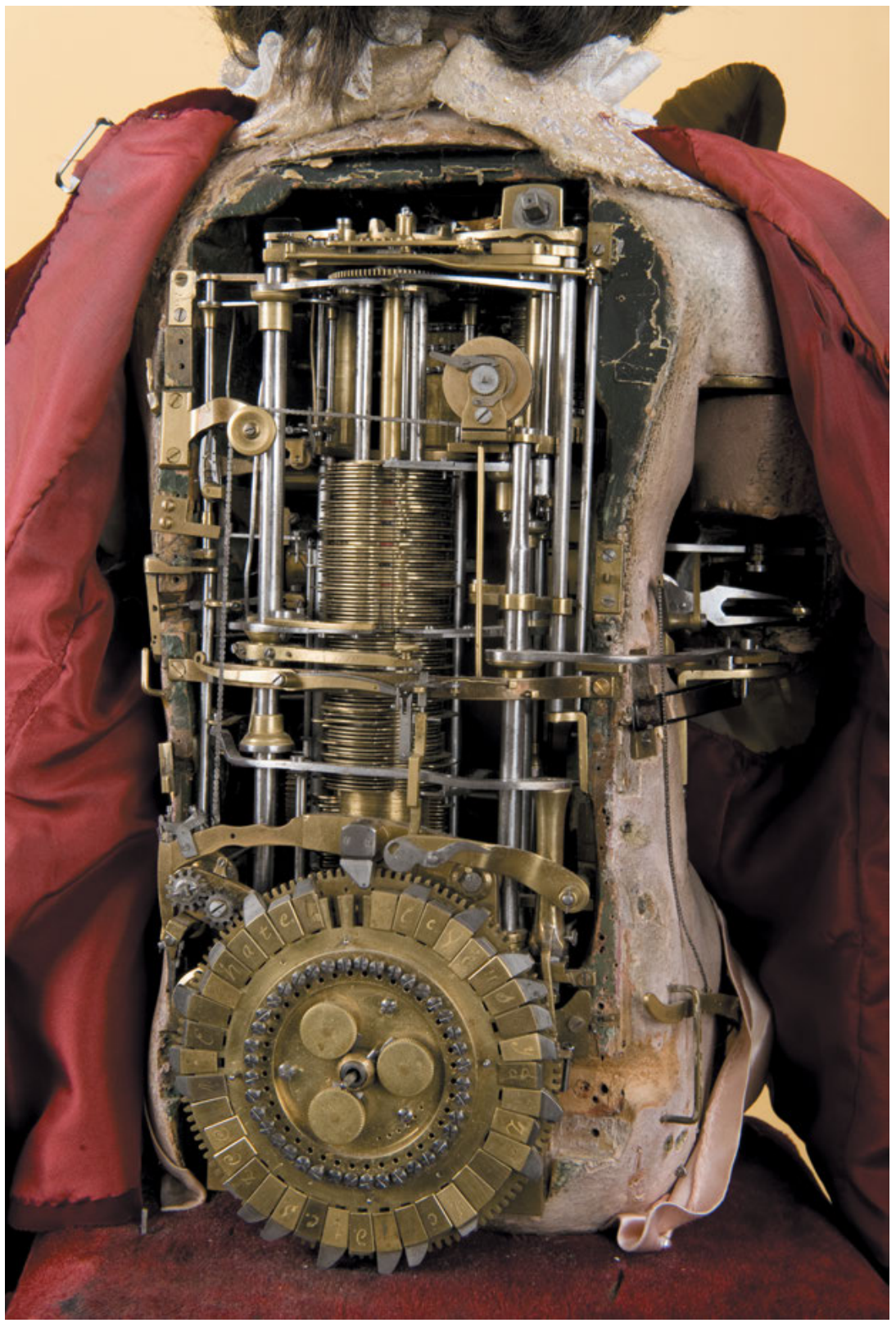

Abb. 1.17: Schriftsteller von Jaquet-Droz. Für die Speicherung der Buchstaben und ihrer Formen nutzt dieser großartige Figurenautomat Kurvenscheiben (Bildmitte). Der Wortlaut des Textes wird mithilfe der kreisrunden Nockenscheibe (unten) festgelegt (@ Musée d'art et d'histoire, Neuenburg). 


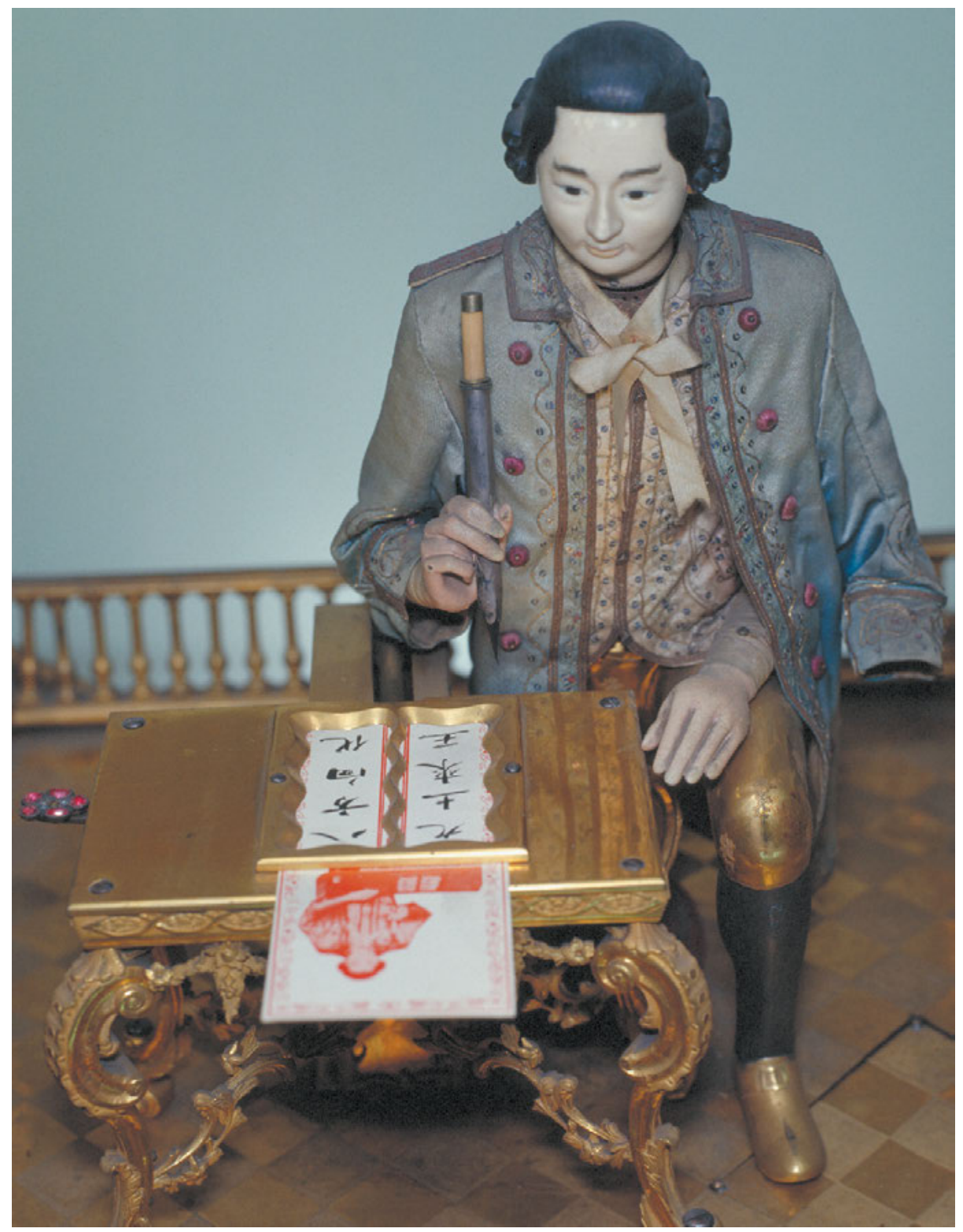

Abb. 1.18: Musikfigurenuhr aus Peking. Der funktionsfähige „Schriftsteller“, der Timothy Williamson (England) zugeschrieben wird, schreibt mit einem Pinsel einen festgelegten kurzen chinesischen Text. Dieses Bild zeigt einen Ausschnitt aus einem mehrstöckigen Turm, der auch eine Uhr und einen Glockenschläger beherbergt (@ Palastmuseum Peking/The Palace Museum, Beijing). 


\subsection{Zeittafel: frühe elektromechanische und elektronische Digitalrechner}

Die folgende Zeittafel (vgl. Tab. 1.15) vermittelt einen weltweiten Überblick über die ersten mechanischen, elektromechanischen und elektronischen programmgesteuerten Rechenmaschinen (Auswahl).

Tab. 1.15: Bedeutende Relais- und Röhrenrechner in zeitlicher Reihenfolge

\begin{tabular}{|c|c|c|c|c|}
\hline \multicolumn{5}{|c|}{ Zeittafel: frühe elektromechanische und elektronische Digitalrechner (Auswahl) } \\
\hline Jahr & Monat & Name & Land & Bauart \\
\hline 1939 & Oktober & Complex computer & USA & elektromechanisch \\
\hline 1941 & Mai & Zuse Z3 & Deutschland & elektromechanisch \\
\hline 1942 & Mai & Atanasoff-Berry-Rechner & USA & elektronisch \\
\hline 1943 & Dezember & Colossus 1 & England & elektronisch \\
\hline 1944 & August & Harvard mark 1/IBM ASCC & USA & elektromechanisch \\
\hline 1945 & März & Zuse Z4 & Deutschland & elektromechanisch \\
\hline 1946 & Februar & Eniac & USA & elektronisch \\
\hline 1948 & Januar & IBM SSEC & USA & gemischt \\
\hline 1948 & Juni & Manchester baby/SSEM & England & elektronisch \\
\hline 1949 & Mai & Edsac 1 & England & elektronisch \\
\hline 1949 & August & Binac & USA & elektronisch \\
\hline 1949 & November & Csirac & Australien & elektronisch \\
\hline 1950 & Februar & Bark & Schweden & elektromechanisch \\
\hline 1950 & Mai & Pilot Ace & England & elektronisch \\
\hline 1950 & Juni & Seac & USA & elektronisch \\
\hline 1950 & August & Swac & USA & elektronisch \\
\hline 1950 & November & Mesm & Ukraine & elektronisch \\
\hline 1950 & Dezember & Era 1101 & USA & elektronisch \\
\hline 1951 & Februar & Ferranti mark 1 & England & elektronisch \\
\hline 1951 & März & Univac 1 & USA & elektronisch \\
\hline 1951 & April & Whirlwind & USA & elektronisch \\
\hline 1951 & Frühling & Leo 1 & England & elektronisch \\
\hline 1952 & Jahresanfang & Edvac & USA & elektronisch \\
\hline 1952 & Juni & IAS-Rechner & USA & elektronisch \\
\hline 1952 & Dezember & IBM 701 & USA & elektronisch \\
\hline 1953 & Juli & IBM 650 & USA & elektronisch \\
\hline
\end{tabular}

(C) Bruderer Informatik, CH-9401 Rorschach 2020

Anmerkung

Der Complex computer und $\mathrm{ABC}$ waren festprogrammiert. 


\subsection{Frühe Transistorrechner}

Der Bau von Relaismaschinen begann in der zweiten Hälfte der 1930er Jahre, die Röhrenmaschinen folgten in der ersten Hälfte der 1940er Jahre. Die Transistorrechner entstanden in der ersten Hälfte der 1950er Jahre. Obwohl diese Halbleitermaschinen 20 Jahre jünger sind als ihre mechanischen Vorläufer, liegen ihre Anfänge noch mehr im Dunkeln.

- MV 950

Richard L. Grimsdale, Douglas C. Webb, Universität Manchester

15. November 1953;

Richard Grimsdale und Douglas Webb von Thomas Kilburns Gruppe haben laut Lavington 1953 an der Universität Manchester den ersten Transistorrechner gebaut (siehe Simon Lavington: A history of Manchester computers, Manchester university press, Manchester 1980, Seiten 27-30, sowie Simon Lavington: Early British computers, Manchester university press, Manchester 1980, Seiten 48-51). Beteiligt waren auch J. R. Foster (Diplomarbeit zu Transistorrechnern, Universität Manchester, Oktober 1954) und G. B. B. Chaplin. Es gab zwei Versuchsmaschinen. Die erste war im November 1953 lauffähig, die zweite folgte im April 1955. Die Transistoren („Kristalltrioden“) waren zu Beginn allerdings weniger zuverlässig als Vakuumröhren. Die Firma Metropolitan-Vickers company (Manchester) hatte die Maschine 1956 als Metrovick 950 (MV 950) herausgebracht und sechs Geräte hergestellt.

- Tradic (transistor airborne digital computer);

Jean Howard Felker, J. R. Harris, Bell Telephone Laboratories, Murray Hill, New Jersey;

Probebetrieb: Januar 1954, Vorführung: Mai 1955; spätere Modelle: flyable Tradic, Leprechaun von J. A. Githens, J. A. Baird, XMH-3 Tradic;

- Cadet

Edward Cooke-Yarborough; Robert Barnes, J. H. Stephen, G. A. Howells, Atomic energy research establishment, Harwell;

Probebetrieb: Februar 1955, Dauerbetrieb August 1956;

- TX-O (transistorized experimental computer zero);

William Papian, Wesly Clark, Kenneth Olsen, MIT (Lincoln laboratory), Cambridge, Massachusetts;

Erstlauf: 1956; späteres Modell: TX-2;

- Transac $S 1000$ (Transistor automatic computer)

Philco corporation, Philadelphia;

1957

Erstlauf S 1000: Mai 1957;

S 2000 (1958), erster im Handel erhältlicher Transistorrechner;

- Mailüfterl

Heinz Zemanek, Technische Hochschule Wien (heute Technische Universität, Wien);

Bauzeit: 1956 - Mai 1958. 
Es folgten weitere Rechner wie IBM 608 (Rechenlocher, 1955), Larc (Univac, 1957), National Elliott 803 (1958), IBM 1610 (1958) und Stretch (IBM, 1960).

Quellen

Friedrich Bauer: Historische Notizen zur Informatik, Springer-Verlag, Berlin, Heidelberg 2009, Seiten 57-60,

Jean Howard Felker: Performance of Tradic transistor digital computer, in: Proceedings of the Eastern joint computer conference, Philadelphia, Dezember 1954, Seiten 46-48,

Thomas Kilburn; Richard L. Grimsdale, Douglas C. Webb: A transistor digital computer with a magnetic drum store, in: Proceedings IEE (Institution of electrical engineers), 1956, Band 103, Teil B, Nachträge 1-3, Seiten 390-406.

Über das Aufkommen der frühen Transistorrechner ist wenig bekannt (vgl. Tab. 1.16).

Tab. 1.16: Die ersten Transistorrechner

\begin{tabular}{|c|c|c|c|}
\hline $\begin{array}{l}\text { Frühe Transistorrechner (Auswahl) } \\
\text { Hersteller }\end{array}$ & Land & Rechnername & Jahr \\
\hline Universität Manchester & Großbritannien & - & 1953 \\
\hline Bell Telephone Laboratories, Murray Hill, New Jersey & USA & Tradic & 1954 \\
\hline Atomic energy research establishment, Harwell & Großbritannien & Cadet & 1955 \\
\hline Massachusetts Institute of Technology, Cambridge & USA & TX-0 & 1956 \\
\hline Metropolitan-Vickers, Manchester & Großbritannien & MV 950 & 1956 \\
\hline Philco, Philadelphia & USA & Transac S 1000 & 1957 \\
\hline Technische Universität Wien & Österreich & Mailüfterl & 1958 \\
\hline
\end{tabular}

(c) Bruderer Informatik, CH-9401 Rorschach 2020

\subsection{Jahrhundertelang geringer Rechenbedarf}

$\mathrm{Zu}$ den frühen Rechenhilfsmitteln gehören Rechenbretter und Multiplikationstafeln. Das schwerfällige römische Zahlensystem, das keine Ziffer Null kannte, verhinderte eine anspruchsvolle Mathematik. Nach der griechischen Blütezeit kam es zu einem Niedergang, unter dem auch die Naturwissenschaften litten. Eine Wende brachte die allmähliche Einführung des Stellenwertsystems mit den indisch-arabischen Ziffern. Ein Markstein war die Entdeckung der Logarithmen durch Jost Bürgi und John Napier. Die Multiplikation konnte damit auf die Addition, die Division auf die Subtraktion von Strecken zurückgeführt werden.

Im 17. Jahrhundert wurde in England der logarithmische Rechenstab erfunden. Er setzte sich aber nur langsam als Alltagswerkzeug durch. Die Nachfrage nach Rechenmitteln blieb vergleichsweise gering. Der größte Bedarf bestand wohl in der Himmelskunde und im Vermessungswesen. Fehlerhafte mathematische Tabellen veranlassten 
Charles Babbage in der ersten Hälfte des 19. Jahrhunderts zum (erfolglosen) Bau einer Differenzenmaschine. Ab etwa 1850 wurde das thomassche Arithmometer in beachtlichen Mengen vertrieben. Das Verlangen nach maschineller Unterstützung hielt sich allerdings weiterhin in Grenzen. Denn die schweren Geräte galten allgemein als teuer. Überdies war die Handhabung der Tischrechenmaschinen umständlich, u.a. die Zahleneingabe über Schieber, Griffel, Drehscheiben, Drehräder. Elektromechanische Rechenmaschinen mit Tastatur, Speicher und Druckwerk kamen erst im 20. Jahrhundert auf den Markt.

Wegen der bewaffneten Auseinandersetzungen in den 1940er Jahren stieg die Nachfrage nach Rechenleistungen stark, besonders für die Ermittlung der Flugbahn von Geschossen (Ballistik, Lehre von den Flugbahnen geschossener Körper), das Entziffern von geheimen Funksprüchen, die Kryptanalyse, und den Bau der Atombombe.

\section{Falscheinschätzung des Rechenbedarfs}

Manche Pioniere haben den Rechenbedarf völlig falsch eingeschätzt. Man glaubte, mit wenigen Großrechnern die weltweite Nachfrage abdecken zu können. Niemand hat geahnt, welche Bedeutung die Computer innerhalb eines halben Jahrhunderts erlangen würden. Ein Beispiel: Am 13. Oktober 1949 und am 2. November 1949 schrieb Eduard Stiefel, der die Informatik in der Schweiz begründet hatte, dass Großrechner vorläufig sehr teure Einzelgeräte seien, von denen (wenigstens in Europa) auch in den nächsten Jahren jedes Land höchstens eines besitzen werde (Gesuch an die Eidgenössische Volkswirtschaftsstiftung bzw. an den Jubiläumsfonds ETH 1930). In der zweiten Hälfte des 20. Jahrhunderts benötigten Technik, Wissenschaft, Industrie, Banken, Versicherungen, Handel und Verwaltung immer leistungsfähigere Anlagen für die automatische Datenverarbeitung. Für Privatleute blieben die Maschinen hingegen lange Zeit unerschwinglich.

In einem Beitrag im Time magazine von 1977 wird der Kenneth Olsen (Gründer von Digital Equipment Corporation) mit folgender Aussage zitiert:

„There is no reason for any individual to have a computer in their home.“ (siehe Edgar H. Schein; Peter S. de Lisi; Paul J. Kampas; Michael Sonduck: DEC is dead, long live DEC, Berrett-Koehler publishers, Inc., San Francisco 2003, Seite 38).

„Kein Mensch braucht zu Hause einen Computer“ (siehe Edgar H. Schein; Peter S. de Lisi; Paul J. Kampas; Michael Sonduck: Aufstieg und Fall von Digital Equipment Corporation, EHP-Verlag Andreas Kohlhage, Bergisch Gladbach 2006, Seite 49).

\subsection{Pionierinnen und Pioniere als ACM- und IEEE-Preisträger}

Der Turingpreis (A. M. Turing award) der amerikanischen Association for computing machinery (ACM) gilt als „Nobelpreis“ der Informatik. Er wurde bisher vorwiegend für den Bereich Programme, seltener für Geräte vergeben. Anbei ein Verzeichnis ausge- 
wählter Preisträger aus der Frühgeschichte (vgl. Tab. 1.17). Sie stammen meist aus den USA. Aus dem deutschsprachigen Raum ist nur Niklaus Wirth zu finden.

Tab. 1.17: Turingpreisträger aus der Frühgeschichte der Informatik (Auswahl)

\begin{tabular}{lll}
\hline \multicolumn{3}{l}{ Wer hat den Turingpreis erhalten? } \\
Jahr & Name & Land \\
\hline 1966 & Alan Perlis & USA \\
1967 & Maurice Wilkes & Großbritannien \\
1970 & James Wilkinson & Großbritannien \\
1972 & Edsger Dijkstra & Niederlande \\
1974 & Donald Knuth & USA \\
1977 & John Backus & USA \\
1984 & Niklaus Wirth & Schweiz \\
2005 & Peter Naur & Dänemark
\end{tabular}

(C) Bruderer Informatik, CH-9401 Rorschach 2020

Das amerikanische Institute of electrical and electronics engineers (IEEE) hat mit dem Informatikpionierpreis (Computer pioneer award) zahlreiche Wegbereiterinnen und Wegbereiter ausgezeichnet (vgl. Tab. 1.18). Im gleichen Jahr sind mehrere Preisträger möglich. Geehrt wurden auch Wissenschaftler aus Deutschland, Österreich und der Schweiz: Friedrich Bauer, Niklaus Wirth, Heinz Zemanek.

Der Erfinder des World Wide Web, Tim Berners-Lee (Großbritannien), erhielt 2016 den Turingpreis.

Tab. 1.18: Informatikpionierpreisträgerinnen und -preisträger aus der Frühgeschichte (Auswahl)

\begin{tabular}{|c|c|c|c|c|c|}
\hline \multicolumn{6}{|c|}{ Wer hat den Informatikpionierpreis erhalten? } \\
\hline \multirow{2}{*}{$\frac{\text { Jahr }}{1982}$} & \multicolumn{5}{|c|}{ Preisträgerinnen/Preisträger } \\
\hline & Arthur Burks & $\begin{array}{l}\text { Harry } \\
\text { Huskey }\end{array}$ & & & \\
\hline 1984 & $\begin{array}{l}\text { John } \\
\text { Atanasoff }\end{array}$ & $\begin{array}{l}\text { Jerrier } \\
\text { Haddad }\end{array}$ & $\begin{array}{l}\text { Nicholas } \\
\text { Metropolis }\end{array}$ & $\begin{array}{l}\text { Nathaniel } \\
\text { Rochester }\end{array}$ & $\begin{array}{l}\text { Willem } \\
\text { van der Poel }\end{array}$ \\
\hline 1985 & $\begin{array}{l}\text { Alan } \\
\text { Perlis }\end{array}$ & $\begin{array}{l}\text { David } \\
\text { Wheeler }\end{array}$ & $\begin{array}{l}\text { Heinz } \\
\text { Zemanek }\end{array}$ & & \\
\hline 1986 & $\begin{array}{l}\text { Peter } \\
\text { Naur }\end{array}$ & $\begin{array}{l}\text { Adriaan } \\
\text { van Wijngaarden }\end{array}$ & & & \\
\hline 1987 & $\begin{array}{l}\text { Robert } \\
\text { Everett }\end{array}$ & $\begin{array}{l}\text { Niklaus } \\
\text { Wirth }\end{array}$ & & & \\
\hline 1988 & $\begin{array}{l}\text { Friedrich } \\
\text { Bauer }\end{array}$ & & & & \\
\hline
\end{tabular}




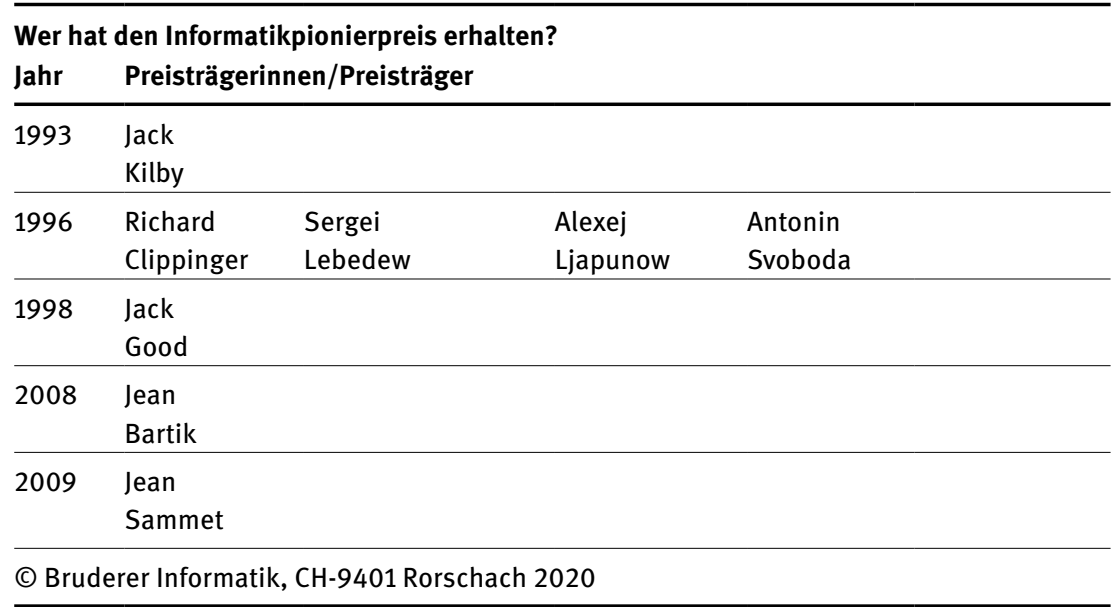

Weitere Preisträger waren z.B. Linus Torvalds (2014, Finnland) und Larry Page (2018, USA).

Hinweis

$\mathrm{Zu}$ den bedeutendsten Mathematikauszeichnungen zählen der Abel-Preis und die Fields-Medaille.

\subsection{Jubiläen zur Geschichte der Rechentechnik}

In den letzten Jahren wurden mehrere Pionierinnen und Pioniere und ihre Werke gefeiert. Einige ausgewählte Beispiele:

$\begin{array}{llll}1991 & \text { Charles Babbage } & \text { England } & \text { 200. Geburtstag } \\ 1992 & \text { Adam Ries } & \text { Deutschland } & \text { 500. Geburtstag } \\ 2010 & \text { Konrad Zuse } & \text { Deutschland } & \text { 100. Geburtstag } \\ 2012 & \text { Alan Turing } & \text { England } & \text { 100. Geburtstag } \\ 2014 & \text { John Napier } & \text { Schottland } & \text { 400 Jahre Logarithmen } \\ 2015 & \text { Ada Lovelace } & \text { England } & \text { 200. Geburtstag } \\ 2016 & \text { Gottfried Wilhelm Leibniz } & \text { Deutschland } & \text { 300. Todestag } \\ 2019 & \text { Leonardo da Vinci } & \text { Italien } & \text { 500. Todestag } \\ 2020 & \text { Jost Bürgi } & \text { Schweiz } & \text { 400 Jahre Logarithmen } \\ 2023 & \text { Blaise Pascal } & \text { Frankreich } & \text { 400. Geburtstag }\end{array}$

Weitere Ereignisse

201710 Jahre internetfähiges Mobiltelefon

201930 Jahre World Wide Web

201950 Jahre Internet 
